\title{
Argonne
}

ANL/EVS-15/7

\section{Reassessment of Floodplain Wetland Connections in the Middle Green River, Utah}

\author{
Environmental Science Division
}

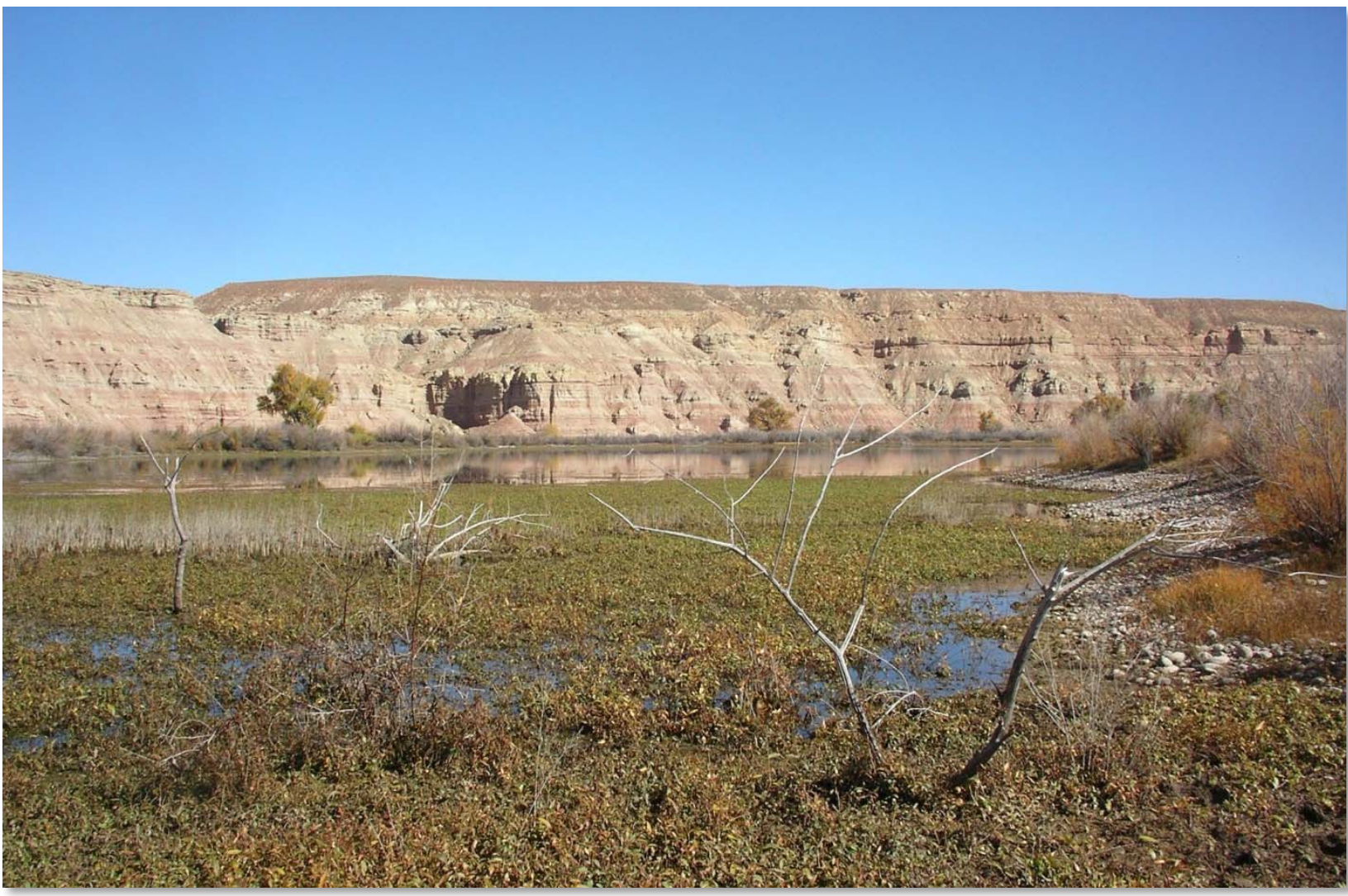




\begin{abstract}
About Argonne National Laboratory
Argonne is a U.S. Department of Energy laboratory managed by UChicago Argonne, LLC under contract DE-AC02-06CH11357. The Laboratory's main facility is outside Chicago, at 9700 South Cass Avenue, Argonne, Illinois 60439. For information about Argonne and its pioneering science and technology programs, see www.anl.gov.
\end{abstract}

\title{
DOCUMENT AVAILABILITY
}

Online Access: U.S. Department of Energy (DOE) reports produced after 1991 and a growing number of pre-1991 documents are available free via DOE's SciTech Connect (http://www.osti.gov/scitech/).

Reports not in digital format may be purchased by the public from the National Technical Information Service (NTIS):

U.S. Department of Commerce

National Technical Information Service

5301 Shawnee Road

Alexandria, VA 22312

www.ntis.gov

Phone: (800) 553-NTIS (6847) or (703) 605-6000

Fax: (703) 605-6900

Email: orders@ntis.gov

Reports not in digital format are available to DOE and DOE contractors from the Office of Scientific and Technical Information (OSTI):

U.S. Department of Energy

Office of Scientific and Technical Information

P.O. Box 62

Oak Ridge, TN 37831-0062

www.osti.gov

Phone: (865) 576-8401

Fax: (865) 576-5728

Email: reports@osti.gov

\section{Disclaimer}

This report was prepared as an account of work sponsored by an agency of the United States Government. Neither the United States Government nor any agency thereof, nor UChicago Argonne, LLC, nor any of their employees or officers, makes any warranty, express or implied, or assumes any legal liability or responsibility for the accuracy, completeness, or usefulness of any information, apparatus, product, or process disclosed, or represents that its use would not infringe privately owned rights. Reference herein to any specific commercial product, process, or service by trade name, trademark, manufacturer, or otherwise, does not necessarily constitute or imply its endorsement, recommendation, or favoring by the United States Government or any agency thereof. The views and opinions of document authors expressed herein do not necessarily state or reflect those of the United States Government or any agency thereof, Argonne National Laboratory, or UChicago Argonne, LLC. 
ANL/EVS-15/7

\section{Reassessment of Floodplain Wetland Connections in the Middle Green River, Utah}

prepared by

K.E. LaGory, L.J. Walston, and C.C. Weber

Environmental Science Division, Argonne National Laboratory

prepared for

Upper Colorado River Endangered Fish Recovery Program

December 2016 
This page intentionally left blank. 


\section{CONTENTS}

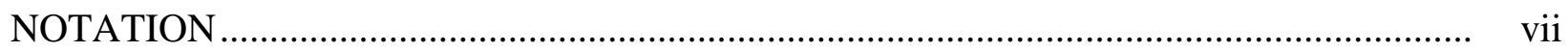

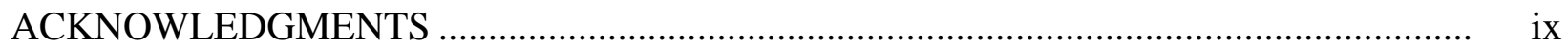

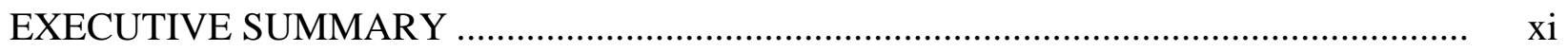

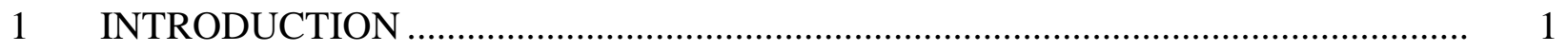

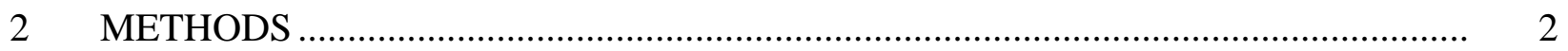

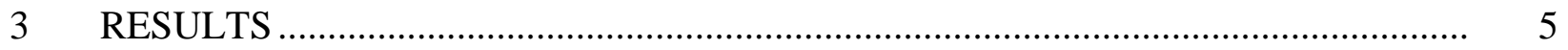

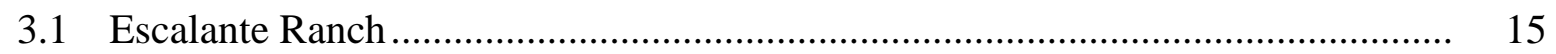

3.2 Bonanza Bridge ............................................................................................. 18

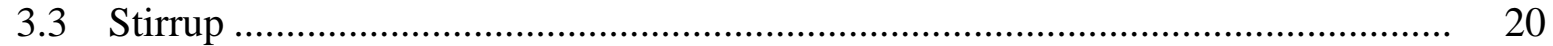

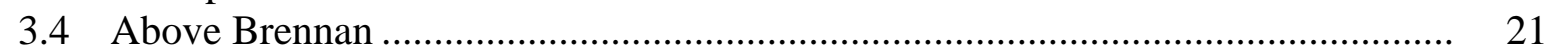

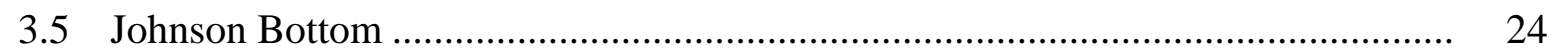

3.6 Leota Bottom …………………….................................................................... 25

3.7 Results Summary ………………………………........................................... 27

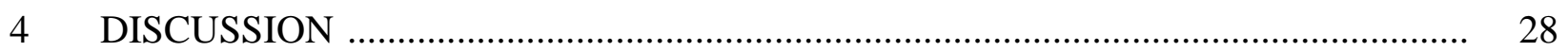

5 CONCLUSIONS ........................................................................................ 29

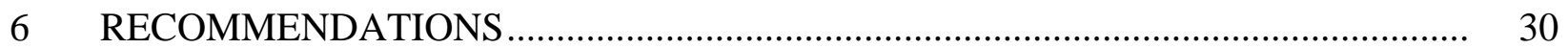

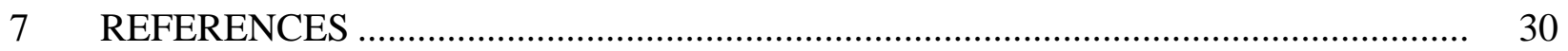

APPENDIX A: USGS Stage-Flow Relationships at the Jensen and Ouray Gages ................. 34

APPENDIX B: Middle Green River Floodplain Wetland Connection Maps for 2014........... 61

\section{TABLES}

1 Green River Annual Peak Peak Flow at Jensen, Utah from 2005-2014 ........................ 2

2 Summary of Survey Dates and Modeled Local Flow Conditions for Six Floodplain Wetland Sites on the Middle Green River, Utah, in 2014. 


\section{Tables (Cont.)}

3 Breach and Connection Flows at Surveyed Breaches in October 2014 and Comparison to Previously Reported Connection Flows

4 Minimum Connection Flows at Floodplain Wetlands in 2005, 2012, and 2014 for Any Breach, Upstream Breaches, and Downstream Breaches.

$5 \quad$ Fish Passage Flows at Surveyed Breaches in 2005, 2012, and 2014

A-1 USGS Stage-Flow Table for the Jensen Gage (USGS 09261000) in 2005, 2012, and 2014

A-2 USGS Stage-Flow Table for for the Ouray Gage (USGS 9272400) in 2012 and 2014

\section{FIGURES}

$1 \quad$ Green River Floodplain Wetland Survey Locations, October 2014

2 Example Floodplain Wetland Photographs, October 2014..................................... 6

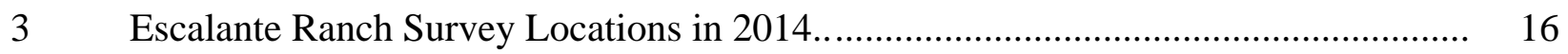

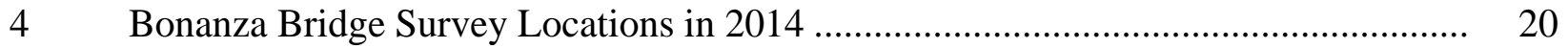

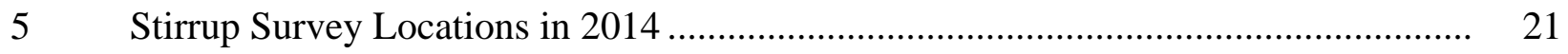

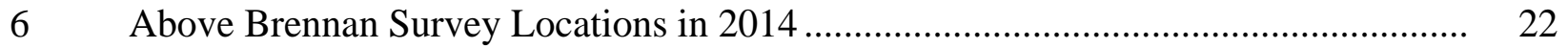

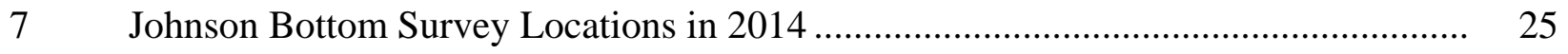

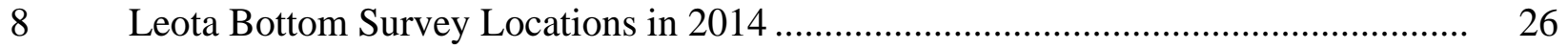

A-1 Relationship Used to Predict Jensen Flow (cfs) Based on Values in Table A-1 ......... 37

A-2 Relationship Used to Predict Jensen Stage (ft) Based on Values in Table A 1 ........... 38

A-3 Relationship Used to Predict Ouray Flow (cfs) Based on Values in Table A 2 .......... 39

A-4 Relationship Used to Predict Ouray Stage (ft) Based on Values in Table A 2............ 39

B-1 Floodplain Wetland Connection Channel and Minimum Connection Flow for ER-IN-3 at 18,100 cfs in 2014 


\section{Figures (Cont.)}

B-2 Floodplain Wetland Connection Channel and Minimum Connection Flow for ER-IN-4 at 20,000 cfs in 2014

B-3 Floodplain Wetland Connection Channel and Minimum Connection Flow for ER-IN-5 at 19,400 cfs in 2014

B-4 Floodplain Wetland Connection Channel and Minimum Connection Flow for ER-IN-6 at 18,900 cfs in 2014

B-5 Floodplain Wetland Connection Channel and Minimum Connection Flow for ER-IN-7 at 17,600 cfs in 2014

B-6 Floodplain Wetland Connection Channel and Minimum Connection Flow for ER-OUT at 8,740 cfs in 2014.

B-7 Floodplain Wetland Connection Channel and Minimum Connection Flow for BB-IN-1 at 19,800 cfs in 2014

B-8 Floodplain Wetland Connection Channel and Minimum Connection Flow for BB-IN-2 at 20,500 cfs in 2014

B-9 Floodplain Wetland Connection Channel and Minimum Connection Flow for BB-IN-3 at 22,200 cfs in 2014

B-10 Floodplain Wetland Connection Channel and Minimum Connection Flow for BB-OUT at 14,900 cfs in 2014

B-11 Floodplain Wetland Connection Channel and Minimum Connection Flow for ST-OUT at $15,700 \mathrm{cfs}$ in 2014

B-12 Floodplain Wetland Connection Channel and Minimum Connection Flow for AB-IN-1 at 15,200 cfs in 2014

B-13 Floodplain Wetland Connection Channel and Minimum Connection Flow for AB-IN-2 at 19,100 cfs in 2014

B-14 Floodplain Wetland Connection Channel and Minimum Connection Flow for AB-IN-3 at 14,600 cfs in 2014.

B-15 Floodplain Wetland Connection Channel and Minimum Connection Flow for AB-OUT at 10,400 cfs in 2014 


\section{Figures (Cont.)}

B-16 Floodplain Wetland Connection Channel and Minimum Connection Flow for JB-OUT-1 at 13,600 cfs in 2014 ............................................................... 78

B-17 Floodplain Wetland Connection Channel and Minimum Connection Flow

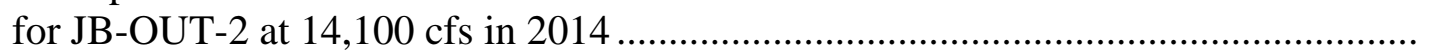

B-18 Floodplain Wetland Connection Channel and Minimum Connection Flow for LB7-IN at 14,500 cfs in 2014................................................................... 80

B-19 Floodplain Wetland Connection Channel and Minimum Connection Flow

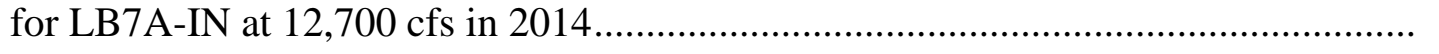




\section{NOTATION}

\section{ACRONYMS, INITIALISMS, AND ABBREVIATIONS}

$\begin{array}{ll}\text { Argonne } & \text { Argonne National Laboratory } \\ \text { Reclamation } & \text { Bureau of Reclamation } \\ \text { Recovery Program } & \text { Upper Colorado River Endangered Fish Recovery Program } \\ \text { USGS } & \text { U.S. Geological Survey } \\ \text { WAPA } & \text { Western Area Power Administration }\end{array}$

\section{UNITS OF MEASURE}

cfs cubic foot (feet) per second

cm centimeter(s)

$\mathrm{ft} \quad$ foot/feet

h hour(s)

km kilometers(s)

mi mile(s)

$\mathrm{m}^{3} \quad$ cubic meter(s)

s second(s)

\section{METRIC UNIT CONVERSIONS}

$\begin{array}{ll}1 \mathrm{cfs} & 0.0283 \mathrm{~m}^{3} / \mathrm{s} \\ 1 \mathrm{ft} & 30 \mathrm{~cm} \\ 1 \mathrm{mi} & 1.61 \mathrm{~km} \\ 1 \text { river mi } & 1.61 \text { river km }\end{array}$


This page intentionally left blank. 


\section{ACKNOWLEDGMENTS}

This project was funded by the Western Area Power Administration (WAPA) Colorado River Storage Project Management Center under contract DE-AC02-06CH11357. We thank Andrew Orr (Argonne National Laboratory) and Jerry Wilhite (WAPA) for assistance in collecting field data. Dan Shaad (Refuge Manager for the Ouray National Wildlife Refuge) provided logistics information for our survey work. 
This page intentionally left blank. 


\section{EXECUTIVE SUMMARY}

The frequency, magnitude, and duration of seasonal overbank flooding in the Green River have been substantially reduced since closure of Flaming Gorge Dam. Flow recommendations (Muth et al. 2000) were developed to assist with conservation and recovery of endangered fish species in the Green River downstream from Flaming Gorge Dam. Among the objectives of these recommendations was to provide for floodplain wetland connection to the river at sufficient frequency and duration to support sustained recruitment of the endangered razorback sucker (Xyrauchen texanus). Although floodplain habitats are important for all four of the endangered Colorado River fishes, the inundation of floodplain wetlands along the middle Green River is particularly important for providing important nursery habitat for young-of-theyear razorback suckers. Restoring or enhancing floodplain wetland connections to the river would provide access to these productive habitats and is expected to support the recovery of the four endangered fish species in the basin.

An uncertainty identified in the Larval Trigger Study Plan (Larval Trigger Study Plan Ad Hoc Committee 2012), a report that identified priorities for geomorphology research in the Upper Colorado River Basin (LaGory et al. 2003), and the Green River Study Plan (Green River Study Plan Ad Hoc Committee 2007) was interannual variability in the flow needed to connect floodplain wetlands and the effect of peak flows on these connecting flows. To address this uncertainty, we conducted a reassessment of floodplain connections in 2012 and found considerable differences from values presented in previous reports, which presumably resulted from the effects of intervening peak flows (LaGory et al. 2016). The present study was developed to determine if changes in connection flow had occurred since 2012.

This report presents the results of floodplain wetland connection surveys conducted in 2014 at six priority floodplain wetland sites along the middle Green River between Jensen and Ouray, Utah. Surveys were conducted at levee breaches and within channels leading from the breaches to the wetlands (referred to here as connection channels) to characterize the flows needed to connect the river's main channel with the floodplain wetlands. Specific objectives of this work were to:

- Determine the minimum flow that would connect floodplain wetlands to the main channel river and allow for the entrainment of larval razorback suckers;

- Determine the minimum flow that would allow the passage of subadult and adult razorback suckers (minimum depth of $1 \mathrm{ft}[30 \mathrm{~cm}]$ based on Burdick 1997) between the wetlands and the river; and

- Compare our 2014 survey results with information collected in 2012 (LaGory et al. 2016), and previously reported results from Tetra Tech (2005) and Bestgen et al. (2011), to determine if and how conditions have changed since those studies were conducted.

Our survey results will be used in conjunction with our 2012 results and the results of other studies conducted under the Larval Trigger Study Plan (Larval Trigger Study Plan Ad Hoc 
Committee 2012) and Green River Study Plan to resolve uncertainties associated with razorback sucker floodplain nursery habitats and factors contributing to recruitment of this species. The evaluation summarized here also will provide important input to the Upper Colorado River Endangered Fish Recovery Program’s ongoing evaluation of the Muth et al. (2000) flow recommendations.

Topographic surveys to determine the flows that would connect the main channel of the Green River to six priority floodplain wetlands were conducted along the middle Green River from October 27 through 30, 2014, between the U.S. Geological Survey (USGS) Jensen gage (USGS 09261000) and the USGS Ouray gage (USGS 9272400). At each wetland location, topographic surveys were conducted of the river surface elevation and at cross sections of the levee breaches and along the connecting channels. This topographic information was used with current USGS stage-discharge relationships to determine minimum flows needed to overtop breaches and connect the floodplain wetlands to the river main channel.

Our 2014 survey identified differences in connection flow of individual levee breaches and associated connection channels from our 2012 survey results (LaGory et al. 2016) and the values in Tetra Tech (2005) and Bestgen et al. (2011). Most of the 2014 connection flow estimates were lower than values we obtained in 2012 (mean difference -1,310 cfs), but still higher than reported values in 2005 (mean difference $+3,544 \mathrm{cfs}$ ). All but 2 of the 19 breaches and associated connection channels surveyed had lower estimated connection flows than in 2012.

The average estimated minimum floodplain connection flow (i.e., the lowest connection flow of any breach at a particular wetland) among the six floodplain wetlands surveyed in 2014 was 12,676 cfs. This is a relatively small mean decrease $(1,807 \mathrm{cfs})$ compared to estimated connection flows in 2012, and a small net decrease since 2005 (100 cfs). However, there was considerable variation among the wetlands in estimated minimum connection flow, ranging from 8,769 cfs at Escalante Ranch ${ }^{1}$ to 15,749 cfs at Stirrup. There was a comparable level of variation in 2012 (10,422 to 17,864 cfs), but much less variation in 2005 (11,166 to 13,000 cfs).

Changes in connection flows differed between upstream and downstream breaches with upstream breaches showing a smaller decrease since 2012 than downstream breaches. The estimated mean minimum connection flow of upstream breaches in 2014 was 17,324 cfs (14,564 to $19,814 \mathrm{cfs})$ compared to $17,697 \mathrm{cfs}(15,704$ to $20,544 \mathrm{cfs})$ and $12,389 \mathrm{cfs}(11,166$ to 13,000 cfs) in 2012 and 2005, respectively. This corresponded to an overall mean decrease for minimum connection flow of upstream breaches of $373 \mathrm{cfs}(-2,267$ to $+1,889 \mathrm{cfs})$ relative to 2012 and an increase of 4,935 cfs relative to 2005 . The estimated mean minimum connection flow of downstream breaches in 2014 was 12,676 cfs (8,769 to 15,749 cfs) compared to 14,271 cfs $(10,422$ to 17,864 cfs) in 2012, and 13,056 cfs (12,433 to 13,900 cfs) in 2005. This corresponded to an overall mean decrease for minimum connection flow of downstream breaches of 1,807 cfs (-2,950 to -53 cfs) relative to 2012, and a 209 cfs decrease (-3,664 to 2,749 cfs) relative to 2005.

Estimated fish passage flows were approximately 2,500 cfs higher than connection flows in the Ouray National Wildlife Refuge wetlands (Johnson Bottom and Leota Bottom) and 3,200

\footnotetext{
${ }^{1}$ Escalante Ranch was referred to as Thunder Ranch in many previous reports.
} 
to 3,400 cfs higher than connection flows in the wetlands further upstream. In 2014, the mean minimum fish passage flow for the floodplain wetlands surveyed was $19,438 \mathrm{cfs}(11,558$ to $25,831 \mathrm{cfs}$ ). The mean minimum fish passage flow for the floodplain wetlands surveyed (i.e., the lowest of all levee breaches in each wetland) was approximately 15,500 cfs (11,558 to 18,966 cfs).

In the wetlands studied, upstream breaches were topographically higher than the wetland, while downstream breaches were lower than the wetland. This topographic variation likely explains differences among breaches in the magnitude of changes in connection flows since 2012. Upstream breaches and their connection channels, which tend to be depositional areas, showed less decrease in connection levels than downstream breaches, which tend to scour as the wetland drains during flood recession.

The mechanism for these reductions in connection flow following the moderately high 2014 peak flow may be a result of differences in sediment concentrations during peak flows in 2011 and 2014. Although such data are not currently available for the study area, it is expected that sediment concentration would be lower during the lower magnitude 2014 flow compared to the higher magnitude 2011 peak flow. A lower sediment load would have made the 2014 flow more erosive and could have resulted in net erosion of 2011 sand deposits. Water entering breaches could have eroded old deposits within connection channels while depositing less new sand. It is not known if a series of moderately high peak flows (18,600 to 21,000 cfs) would further reduce flows needed to connect floodplain wetlands to the main channel. Study of even lower peak flows that only connect downstream wetland breaches (e.g. 11,000 to 15,000 cfs) could also increase our understanding of the effects of peak flow magnitude on floodplain wetland connection. The 2014 results confirm the need for periodic reassessments of levee breaches and connection channels following peak flows.

We recommend the following:

- Resurvey floodplain wetland breaches and their connection channels following peak flows that exceed previously determined connection flows to determine if those peak flows have altered connection flows. It would be interesting to see if the apparent reduction in connection flows that resulted from the moderately high 2014 peak would continue with subsequent moderate peak flows.

- Determine connection of floodplain wetlands annually by direct observation. Ideally, determinations would be made of initial connection flows at upstream and downstream breaches and the degree of filling and draining through the peak flow cycle.

- Measure the surface area of floodplain wetlands after peak flows recede and through the summer and winter to determine if floodplain wetlands provide suitable habitat for razorback suckers between flooding events that reconnect the wetlands to the main channel. 
- Consider modification of floodplain wetland breaches and connection channels to provide connection at a return frequency of 1.5 years (probability of about 67\%) to mimic predam flooding frequency.

- Consider modifications of wetlands to prevent sediment deposition from blocking inflow. These modifications could include (1) actively reconfiguring levee breaches, connection channels, and wetland topography to minimize the blockage of connection channels; (2) filling or allowing the filling of upstream breaches; (3) creating control structures such as those that have been successfully deployed at Stewart Lake, Johnson Bottom, and Old Charlie Wash; and (4) managing vegetation encroachment that exacerbates sediment deposition in breaches and channels. 


\section{INTRODUCTION}

The frequency, magnitude, and duration of seasonal overbank flooding in the Green River have been substantially reduced since closure of Flaming Gorge Dam. Flow recommendations (Muth et al. 2000) were developed to assist with conservation and recovery of endangered fish species in the Green River downstream of Flaming Gorge Dam. These recommendations identified target instantaneous annual spring peak flows in the middle Green River between the confluences of the Yampa River and White River of at least 18,600 cubic feet per second (cfs) (as measured at the Jensen gage) in 1 of 2 years, and flows of at least 18,600 cfs for at least 2 weeks in 4 of 10 years. The intent of these recommendations was to provide floodplain wetland connection to the river at sufficient frequency and duration to support sustained recruitment of the endangered razorback sucker (Xyrauchen texanus).

Although floodplain habitats are important for all four of the endangered Colorado River fishes, the inundation of floodplain wetlands along the middle Green River is particularly important for providing important nursery habitat for young-of-the-year razorback suckers. Restoring or enhancing floodplain wetland connections to the river would provide access to these productive habitats and is expected to improve the recovery of the four endangered fish species in the Green River Basin.

An uncertainty identified in the Larval Trigger Study Plan (Larval Trigger Study Plan Ad Hoc Committee 2012), a report that identified priorities for geomorphology research in the Upper Colorado River Basin (LaGory et al. 2003), and the Green River Study Plan (Green River Study Plan Ad Hoc Committee 2007) was interannual variability in the flow needed to connect floodplain wetlands and the effect of peak flows on these connecting flows.

Floodplain wetland connection assessments following years with peak flows that exceed previous connection flows are important to understand changes in connection flows that may result from scouring or deposition of sediments or debris. In 2012, surveys were conducted to evaluate changes in floodplain connections following the 2011 high peak flows (LaGory et al. 2016). The 2014 peak flow (Table 1) exceeded the 2012 estimated connection flow of many of the wetlands (LaGory et al. 2016), potentially resulting in deposition or erosion in breaches and connection channels.

This report presents the results of floodplain wetland connection surveys conducted in 2014 at six priority floodplain wetland sites along the middle Green River between Jensen and Ouray, Utah. Surveys were conducted at levee breaches and within channels leading from the breaches to the wetlands (referred to here as connection channels) to characterize the flows needed to connect the river's main channel with the floodplain wetlands. Specific objectives of this work were to:

- Determine the minimum flow that would connect floodplain wetlands to the main channel river and allow for the entrainment of larval razorback suckers; 


\section{TABLE 1 Green River Annual Peak Flow at Jensen, Utah from 2005-2014}

\begin{tabular}{cc}
\hline Year & Peak Flow (cfs) \\
\hline 2005 & 19,900 \\
2006 & 19,200 \\
2007 & 12,700 \\
2008 & 24,000 \\
2009 & 19,600 \\
2010 & 20,500 \\
2011 & 32,200 \\
2012 & 10,600 \\
2013 & 11,000 \\
2014 & 20,100 \\
\hline
\end{tabular}

- Determine the minimum flow that would allow the passage of subadult and adult razorback suckers (minimum depth of $1 \mathrm{ft}[30 \mathrm{~cm}]$ based on Burdick 1997) between the wetlands and the river; and

- Compare our 2014 survey results with information collected in 2012 (LaGory et al. 2016), as well as information reported by Tetra Tech (2005) and Bestgen et al. (2011) 2 to determine if and how conditions have changed since those studies were conducted.

Our survey results will be used in conjunction with our 2012 results and the results of other studies conducted under the Larval Trigger Study Plan and Green River Study Plan to resolve uncertainties associated with razorback sucker floodplain nursery habitats and factors contributing to recruitment of this species. The evaluation summarized here also will provide important input to the Upper Colorado River Endangered Fish Recovery Program's ongoing evaluation of the Muth et al. (2000) flow recommendations.

\section{METHODS}

Topographic surveys to determine the flows that would connect the main channel of the Green River to six priority floodplain wetlands were conducted along the middle Green River from October 27 through 30, 2014, between the U.S. Geological Survey (USGS) Jensen gage (USGS 9261000) and the USGS Ouray gage (USGS 9272400) (Figure 1). A summary of survey times and flow conditions at each of the floodplain areas is provided in Table 2. Local flow conditions were estimated using the same methods as in our 2012 study (LaGory et al. 2016),

2 Bestgen (2011) reported connection flows based on several information sources including Tetra Tech (2005). 


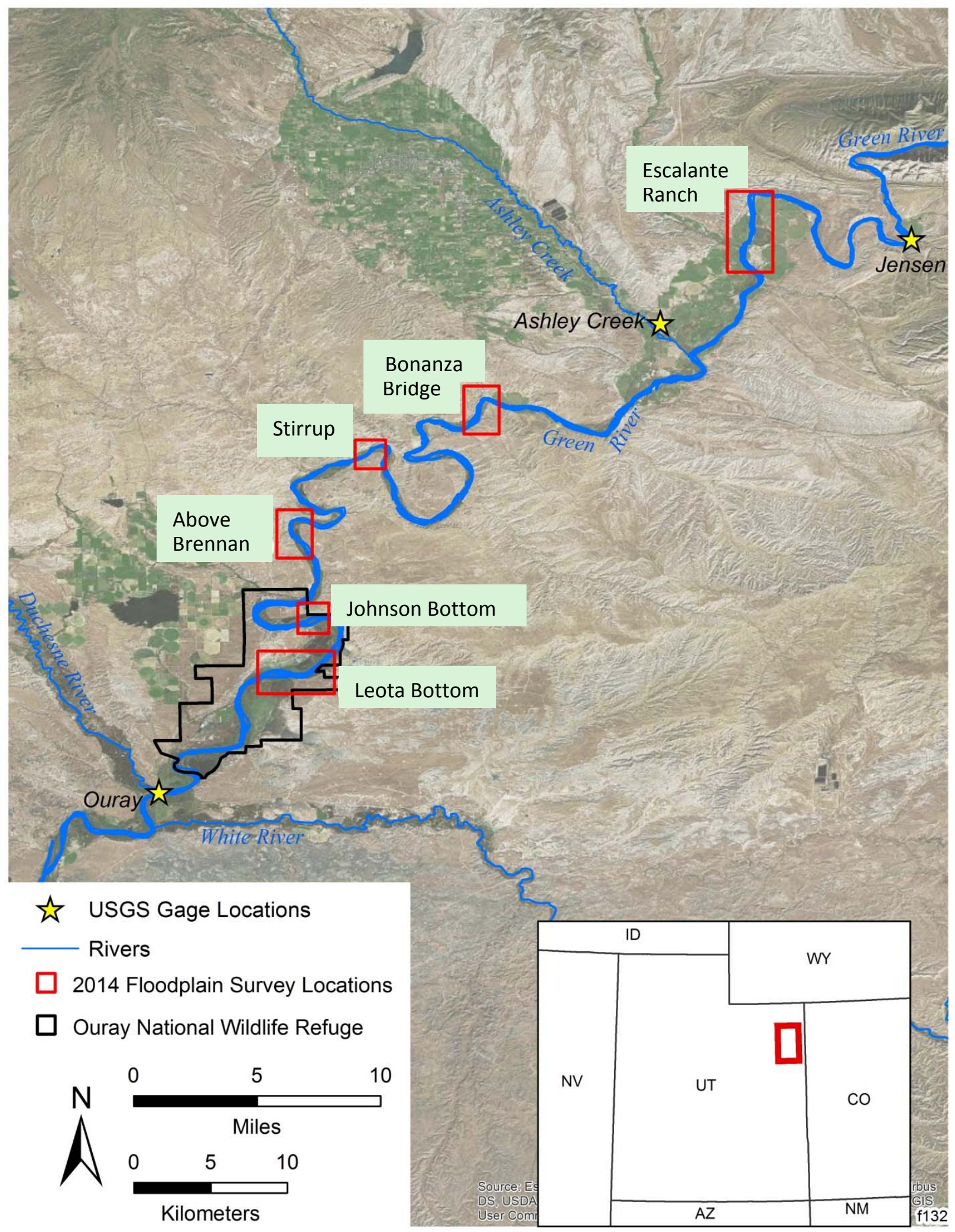

FIGURE 1 Green River Floodplain Wetland Survey Locations, October 2014. Note that Escalante Ranch was referred to as Thunder Ranch in many previous reports. 
TABLE 2 Summary of Survey Dates and Modeled Local Flow Conditions for Six Floodplain Wetland Sites on the Middle Green River, Utah, in 2014

\begin{tabular}{|c|c|c|c|c|c|c|c|}
\hline Site & Date & $\begin{array}{l}\text { Time } \\
\text { (h) }\end{array}$ & $\begin{array}{l}\text { USGS Gage } \\
\text { (distance, }^{\text {mi })^{\mathrm{a}}} \\
\end{array}$ & $\begin{array}{c}\text { Lag- } \\
\text { Adjusted } \\
\text { Gage } \\
\text { Flow } \\
\text { (cfs) } \\
\end{array}$ & $\begin{array}{c}\text { Ashley } \\
\text { Creek } \\
\text { Flow (cfs) }\end{array}$ & $\begin{array}{c}\text { Estimated } \\
\text { Local } \\
\text { Flow } \\
(\mathrm{cfs})^{\mathrm{c}} \\
\end{array}$ & $\begin{array}{l}\text { Estimated } \\
\text { Local } \\
\text { Stage }(\mathrm{ft})^{\mathrm{d}}\end{array}$ \\
\hline Escalante Ranch & $\begin{array}{l}\text { October } \\
27,2014\end{array}$ & $12: 00$ & Jensen (10) & 2,630 & $\mathrm{NA}^{\mathrm{e}}$ & 2,630 & 3.15 \\
\hline Bonanza Bridge & $\begin{array}{c}\text { October } \\
29,2014\end{array}$ & $10: 00$ & Jensen (24) & 2,140 & 75 & 2,215 & 2.85 \\
\hline Stirrup & $\begin{array}{c}\text { October } \\
28,2014\end{array}$ & 13:00 & Jensen (38) & 2,630 & 75 & 2,705 & 3.20 \\
\hline Above Brennan & $\begin{array}{c}\text { October } \\
29,2014\end{array}$ & $15: 00$ & Jensen (44) & 2,450 & 75 & 2,525 & 3.08 \\
\hline Johnson Bottom & $\begin{array}{c}\text { October } \\
30,2014\end{array}$ & $15: 00$ & Ouray $(-12)$ & 2,170 & $\mathrm{NA}^{\mathrm{f}}$ & 2,170 & 15.86 \\
\hline Leota Bottom & $\begin{array}{l}\text { October } \\
30,2014\end{array}$ & $11: 00$ & Ouray (-9) & 2,200 & $\mathrm{NA}^{\mathrm{f}}$ & 2,200 & 15.88 \\
\hline
\end{tabular}

a Values in parentheses indicate distance (mi) away from the nearest USGS stream gage. Positive values are locations downstream from the gage; negative values are locations upstream from the nearest gage.

b The lag-adjusted flow was determined by offsetting the gage flow by the lag time from the gage to the site. The lag time (hours $[h]$ ) was calculated as $h=8.9441 \times D_{w} \times Q_{\max }{ }^{-0.3231}$, where $\mathrm{D}_{\mathrm{w}}$ is the distance (mi) of the wetland from the nearest gage and $\mathrm{Q}_{\max }$ is the maximum hourly flow (cfs) at the gage on the day of the survey.

c For sites associated with the Jensen gage, the local estimated flow was determined by adding the lagadjusted Jensen flow (column 5) with the Ashley Creek flow (column 6).

d The local lag-adjusted stage was determined using the stage-discharge relationships from the most current rating curves for the Jensen and Ouray gages. Stage-flow tables are provided in Appendix A.

e $\quad \mathrm{NA}=$ not applicable; Ashley Creek is downstream of the Escalante Ranch site.

f $\quad$ NA = not applicable; Ashley Creek flow is included in the Ouray gage flow.

and were based on calculated water travel times (i.e., lag-adjusted flows) and distance from the nearest Green River USGS gage sites (Jensen or Ouray; Table 2).

Flow values corresponding to the elevation of all survey points were determined based on their elevation relative to the river elevation and flow at the time of survey, and stage-flow tables provided by USGS for the nearest Green River (Jensen or Ouray gage). Stage-flow tables for each of the gages are provided in Appendix A. For wetlands closer to the Jensen gage and downstream of the Ashley Creek confluence, Ashley Creek flows (USGS 9266500) were added to Jensen flows to determine flow at the site. Flows were relatively steady during the survey period. Jensen flow ranged from 2,040 and 2,260 cfs; Ashley Creek flows were approximately 75 cfs; and Ouray flows ranged from 2,290 and 2,320 cfs. 
Nineteen breach locations were surveyed at the six floodplain wetland sites following the methods described in LaGory et al. (2016). At each location, elevations were determined for the river edge and water surface elevation, and a series of cross sections of levee breaches and the intervening connection channels that separated breaches from the floodplain wetland and provided conveyance of flows between the main channel and wetland at high flows. Example photographs of survey locations are shown in Figure 2.

Using the survey data, the minimum elevation at each cross section was determined. The cross section with the greatest minimum elevation was identified as the location that most limited connection, and the flow associated with that minimum elevation was identified as the connection flow. For flows above the minimum connection flow, topographic information was used to develop relationships between flow and channel depth.

At each floodplain wetland, the minimum flows needed for connection and fish passage were determined for all breach locations and associated connection channels and compared to floodplain connection measurements made in 2012 (LaGory et al. 2016), as well as other reported estimates of connection flows (Tetra Tech 2005; Bestgen et al. 2011).

\section{RESULTS}

Characteristics of floodplain wetland connections in 2014 and changes since 2012 and 2005 are provided in this section. Sites are discussed in order of location along the Green River (upstream to downstream) (Figure 1). A summary of survey results, with comparisons to 2012 values (LaGory et al. 2016) and 2005 values (Tetra Tech 2005; Bestgen et al. 2011) is provided in Table 3. Appendix B contains maps of the connection channel between the river and the floodplain wetland at each location at the minimum connection flow. Tables 4 and 5 summarize minimum connection and minimum fish passage flows, respectively, at each floodplain and at upstream and downstream breaches, and compares the results to previous estimates.

In the descriptions below, the following critical elevations and associated estimated flows are identified for each levee breach and its connection channel:

- River water surface elevation (flow): water surface elevation and associated flow as surveyed at river's edge nearest each levee breach.

- Connection elevation (flow): minimum elevation and associated flow in the connection channel that would allow water to flow between the river and floodplain wetland as determined from a series of cross sections measured between the levee breach and the entrance to the floodplain wetland. 


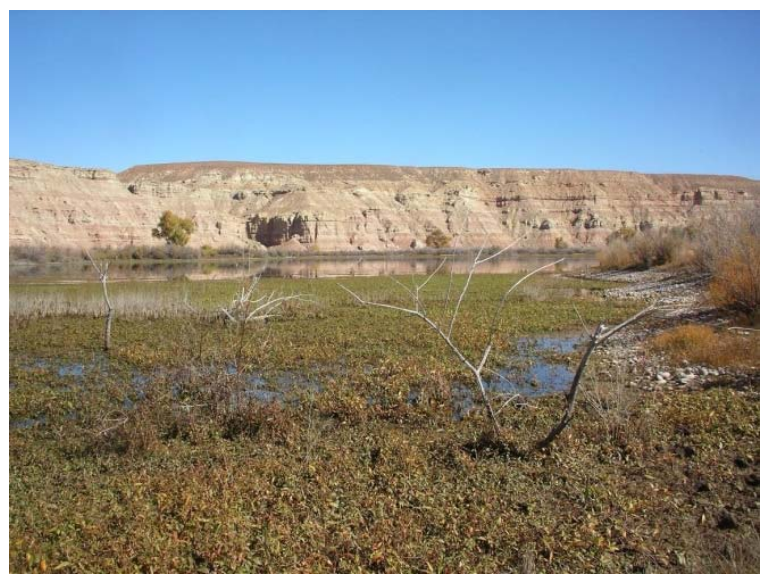

Stirrup Wetland

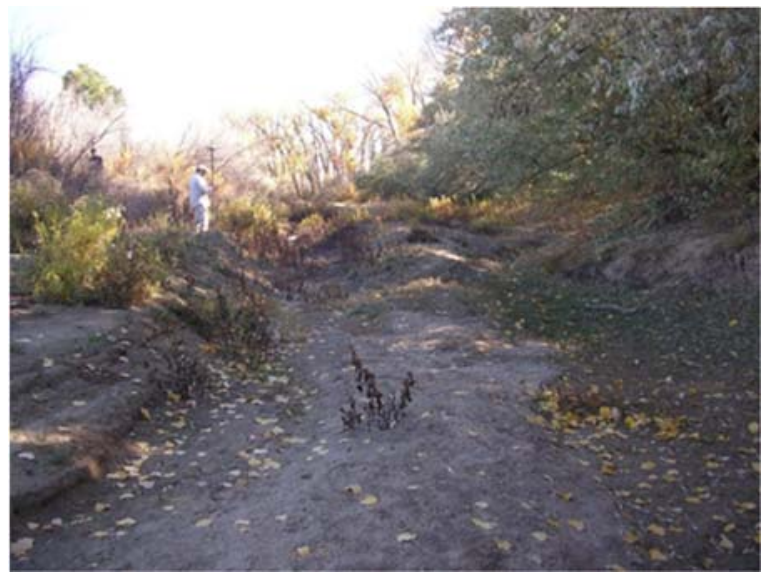

Escalante Ranch Outlet (ER-OUT)

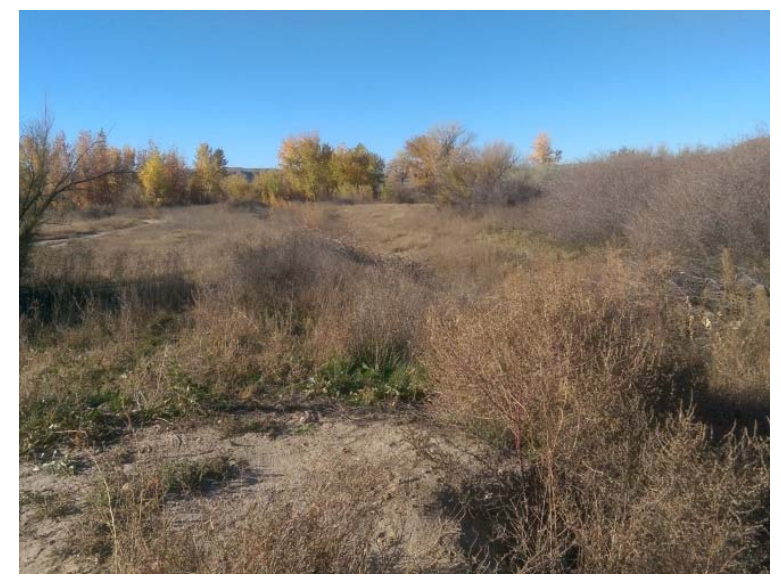

Bonanza Bridge Inlet (BB-IN-1)

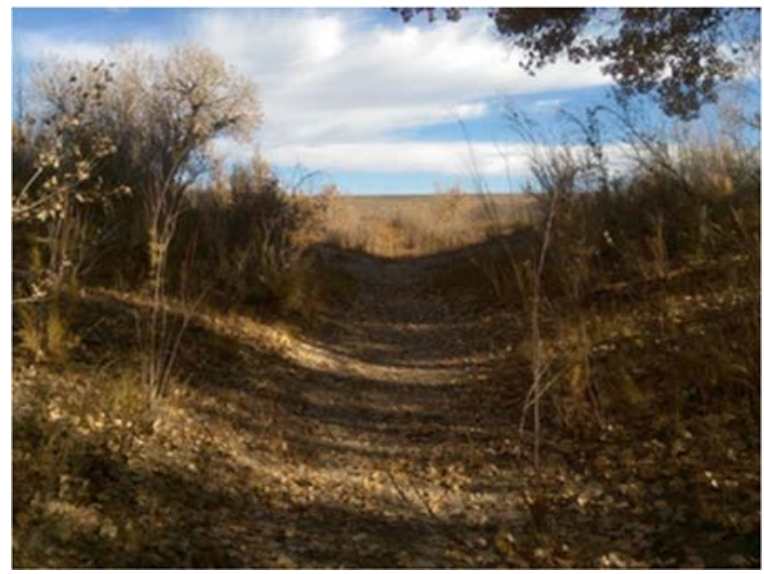

Above Brennan Inlet (AB-IN-3) near wetland

FIGURE 2 Example Floodplain Wetland Photographs, October 2014 
TABLE 3 Connection Flows at Surveyed Breaches in October 2014 and Comparison to Previously Reported Connection Flows

\begin{tabular}{|c|c|c|c|c|c|c|}
\hline $\begin{array}{c}\text { Floodplain } \\
\text { Wetland and } \\
\text { Breach Name }\end{array}$ & $\begin{array}{l}2014 \\
\text { Connection } \\
\text { Flow (cfs) } \\
\end{array}$ & $\begin{array}{l}2012 \\
\text { Connection } \\
\text { Flow }(\mathrm{cfs})^{\mathrm{a}} \\
\end{array}$ & $\begin{array}{l}2005 \\
\text { Connection } \\
\text { Flow }(\mathrm{cfs})^{\mathrm{b}} \\
\end{array}$ & $\begin{array}{l}\text { Change from } \\
2012 \text { to } 2014 \\
\text { (cfs) }\end{array}$ & $\begin{array}{l}\text { Change from } \\
2005 \text { to } 2014 \\
(\mathrm{cfs})^{\mathrm{c}}\end{array}$ & Notes \\
\hline \multicolumn{7}{|c|}{ Escalante Ranch ${ }^{\mathrm{d}}$} \\
\hline ER-IN-3 & 18,100 & 18,100 & 11,900 & 0 & $+6,200$ & $\begin{array}{l}\text { Breach was well-defined, but with some loose sand deposits in } \\
\text { breach. Mass wasting of breach was observed. Sand road crosses } \\
\text { inflow channel, and was higher than breach. Inflow channel fairly } \\
\text { well-defined, but with loose sand. Highest channel cross-section } \\
\text { about two-thirds of way between breach and wetland. Russian } \\
\text { thistle and young tamarisk choked channel. }\end{array}$ \\
\hline ER-IN-4 & 20,000 & 20,300 & 12,933 & -300 & $+7,067$ & $\begin{array}{l}\text { Breach was filled with sand. Sand road crosses inflow channel, } \\
\text { and was higher than breach. Channel to wetland was not well- } \\
\text { defined. Highest channel cross-section near wetland edge. Dense } \\
\text { Russian thistle and dead tamarisk in channel. }\end{array}$ \\
\hline ER-IN-5 & 19,400 & 16,800 & 12,000 & $+2,600$ & $+7,400$ & $\begin{array}{l}\text { Loose sand deposits in breach and inflow channel to road. Highest } \\
\text { channel cross-section near wetland edge. Loose sand decreases in } \\
\text { inflow channel towards wetland. Tamarisk, rabbitbrush, and } \\
\text { annual vegetation species in channel. }\end{array}$ \\
\hline ER-IN-6 & 18,900 & 19,200 & 11,166 & -300 & $+7,734$ & $\begin{array}{l}\text { Breach filled with loose sand almost to height of levee. Sand road } \\
\text { crosses inflow channel. Highest channel cross-section on wetland } \\
\text { side of the road. Channel poorly defined with fairly dense deposits } \\
\text { of Russian olive and patches of tamarisk and sedges. }\end{array}$ \\
\hline ER-IN-7 & 17,600 & 15,300 & 12,000 & $+2,300$ & $+5,600$ & $\begin{array}{l}\text { Breach filled with loose sand almost to height of levee; cutbank at } \\
\text { river edge. Sand road crosses inflow channel. Highest channel } \\
\text { cross-section near breach. No deposits between sand road and } \\
\text { wetland. Tamarisk and annuals in channel. }\end{array}$ \\
\hline
\end{tabular}


Table 3 (Cont.)

\begin{tabular}{cccccc} 
Floodplain & 2014 & 2012 & 2005 & Change from & Change from \\
Wetland and & Connection & Connection & Connection & 2012 to 2014 & $\begin{array}{c}2005 \text { to 2014 } \\
\text { (cfs) }\end{array}$ \\
Breach Name & Flow (cfs) & Flow (cfs) & Flow (cfs) & (cfs) & Notes \\
\hline
\end{tabular}

\section{Escalante Ranch (cont.) \\ ER-OUT $\quad 8,740$}

11,300

$12,300 \quad 12,43$

$-2,560$

$-3,693$

Hard-packed sand in channel near river and breach showing signs of scour. Scour hole with standing water (as observed in 2012) located midway up channel toward wetland. Other areas of standing water in channel with well-developed wetland vegetation (mostly sedges). Highest channel cross-section halfway between breach and wetland. Gravel road crosses channel near wetland. Apparently first connected on April 25, 2014 when flow was 9,910 cfs (Jensen gage). Outlet draining to river on June 13, 2014 $(15,500 \mathrm{cfs})$. Connection reported in 2013 (peak flow 11,000 cfs).

\section{Bonanza Bridge}

BB-IN-1

19,800

20,100

13,000 (actual

$>18,500)$

BB-IN-2

20,500

21,100

13,000 (actual

$>13,900)$

BB-IN-3
22,200

24,100
$-300$

Sand road goes through breach onto large sand bar at river edge, but road berm blocks inlet channel entrance. Another sand road (slightly higher than channel) crosses channel between breach and wetland. No new sand deposited in well-defined channel between breach and wetland suggesting little inflow in 2014. Highest channel cross-section near breach. Large deposit of sand (noted in 2012) where all three inlets feed into wetland. Russian olive and grasses in channel.

Large deposit of sand in breach and channel, completely blocking channel, including large deposit (noted in 2012) where all three inlets feed into wetland. Highest channel cross-section halfway between breach and wetland.

Sand completely fills breach. Channel is without sand deposits, but choked with Russian thistle and some cut brush. Large deposit of sand (noted in 2012) where all three inlets feed into wetland.

Highest channel cross-section near breach. 
Table 3 (Cont.)

\begin{tabular}{|c|c|c|c|c|c|c|}
\hline Floodplain & 2014 & 2012 & 2005 & Change from & Change from & \\
\hline Wetland and & Connection & Connection & Connection & 2012 to 2014 & 2005 to 2014 & \\
\hline Breach Name & Flow (cfs) & Flow $(\mathrm{cfs})^{\mathrm{a}}$ & Flow $(\mathrm{cfs})^{\mathrm{b}}$ & (cfs) & $(\mathrm{cfs})^{\mathrm{c}}$ & Notes \\
\hline \multicolumn{7}{|c|}{ Bonanza Bridge (cont.) } \\
\hline BB-OUT & 14,900 & 17,400 & $\begin{array}{c}13,000 \text { (actual } \\
>13,900)\end{array}$ & $-2,500$ & $+1,000$ & $\begin{array}{l}\text { Two breach inlets mostly filled with sand. Sand and gravel road to } \\
\text { breach serves as main inlet channel. Road passes through } \\
\text { connection channel and breach; several additional small roads } \\
\text { cross broad forest swale, which also serves to connect wetland to } \\
\text { river at high flows. Highest channel cross-section along access } \\
\text { road/channel halfway between the downstream breach and } \\
\text { wetland. }\end{array}$ \\
\hline \multicolumn{7}{|l|}{ Stirrup } \\
\hline ST-OUT & 15,700 & 16,900 & 13,000 & $-1,200$ & $+2,700$ & $\begin{array}{l}\text { Breach is packed sand with no new deposits. Area between river } \\
\text { and breach lost since } 2012 \text { and there is a sharp drop to the river. } \\
\text { Narrow incised channel, without sand deposits, leads from river to } \\
\text { wetland. Young willows and annuals in channel. Highest channel } \\
\text { cross-section just past breach. No change from } 2012 \text { in staff gage } \\
\text { burial depth ( } 0.8 \mathrm{ft}) \text {. Stirrup was full on June } 4,2014 \text { (18,600 cfs). } \\
\text { Stirrup water level through breach was equal to river flow } \\
\text { (15,500 cfs) on June 13, } 2014 \text {. }\end{array}$ \\
\hline
\end{tabular}

Stirrup water level through breach was equal to river flow 
Table 3 (Cont.)

\begin{tabular}{|c|c|c|c|c|c|c|}
\hline $\begin{array}{c}\text { Floodplain } \\
\text { Wetland and } \\
\text { Breach Name }\end{array}$ & $\begin{array}{c}2014 \\
\text { Connection } \\
\text { Flow (cfs) } \\
\end{array}$ & $\begin{array}{c}2012 \\
\text { Connection } \\
\text { Flow }(\mathrm{cfs})^{\mathrm{a}} \\
\end{array}$ & $\begin{array}{c}2005 \\
\text { Connection } \\
\text { Flow }(\mathrm{cfs})^{\mathrm{b}} \\
\end{array}$ & $\begin{array}{c}\text { Change from } \\
2012 \text { to } 2014 \\
\text { (cfs) }\end{array}$ & $\begin{array}{c}\text { Change from } \\
2005 \text { to } 2014 \\
\text { (cfs) }^{\mathrm{c}}\end{array}$ & Notes \\
\hline \multicolumn{7}{|c|}{ Above Brennan } \\
\hline AB-IN-1 & 15,200 & 16,400 & 13,000 & $-1,200$ & $+2,200$ & $\begin{array}{l}\text { Breach mostly filled with sand then slopes down to wetland. Wide } \\
\text { sandy channel to wetland with some young willows and annuals. } \\
\text { Highest channel cross-section just past breach. No change in staff } \\
\text { gage burial depth from } 2012 \text { ( } 0.6 \mathrm{ft} \text { ). Above Brennan had water } \\
\text { flowing through at least two of the inlets on June 4, 2014, at } \\
18,600 \mathrm{cfs} \text {, and on June 13, } 2014 \text { at } 15,500 \mathrm{cfs} \text {. }\end{array}$ \\
\hline AB-IN-2 & 19,100 & 19,500 & 13,000 & -400 & $+6,100$ & $\begin{array}{l}\text { Breach is packed sand with no new deposits. Very narrow channel } \\
\text { passes through dense willow thicket. No apparent deposition in } \\
\text { channel. Highest channel cross-section one-fourth of the distance } \\
\text { between breach and wetland. No change in staff gage burial depth } \\
\text { from } 2012 \text { ( } 0.9 \mathrm{ft}) \text {. Above Brennan had water flowing through at } \\
\text { least two of the inlets on June 4, } 2014 \text { at 18,600 cfs, and on June } \\
\text { 13, } 2014 \text { at 15,500 cfs. }\end{array}$ \\
\hline \multicolumn{7}{|c|}{ Above Brennan (cont.) } \\
\hline AB-IN-3 & 14,600 & 18,500 & 13,000 & $-3,900$ & $+1,600$ & $\begin{array}{l}\text { Breach is packed sand with no new deposits. Very narrow channel } \\
\text { passes through dense willow thicket. No apparent deposition in } \\
\text { channel. Highest channel cross-section just past the breach. Above } \\
\text { Brennan had water flowing through at least two of the inlets on } \\
\text { June } 4,2014 \text { at } 18,600 \mathrm{cfs} \text {, and on June } 13,2014 \text { at } 15,500 \mathrm{cfs} \text {. }\end{array}$ \\
\hline AB-OUT & 10,400 & 9,990 & 13,000 & +410 & $-2,600$ & $\begin{array}{l}\text { Very narrow incised channel through a broad mud breach and } \\
\text { wide channel vegetated with grasses. Beaver dam and large tree } \\
\text { trunks across channel obstruct flow; no sand deposits. Highest } \\
\text { channel cross-section two-thirds of the way between breach and } \\
\text { wetland. No change in staff gage burial depth from } 2012 \text { ( } 3.7 \mathrm{ft} \text { ). } \\
\text { Above Brennan had water flowing through at least two of the } \\
\text { inlets on June 4, } 2014 \text { at 18,600 cfs, and on June 13, } 2014 \text { at } \\
15,500 \text { cfs (Jensen gage). Water filled the outlet channel on May } \\
27,2014 \text { at } 14,600 \text { cfs, but water was not yet flowing into the } \\
\text { wetland. }\end{array}$ \\
\hline
\end{tabular}


Table 3 (Cont.)

\begin{tabular}{cccccc} 
Floodplain & 2014 & 2012 & 2005 & Change from & Change from \\
Wetland and & Connection & Connection & Connection & 2012 to 2014 & $\begin{array}{c}2005 \text { to 2014 } \\
\text { (cfs) }\end{array}$ \\
Breach Name & Flow (cfs) & Flow (cfs) $)^{\text {c }}$ & Flow (cfs) & (cfs) & Notes \\
\hline
\end{tabular}

\begin{tabular}{|c|c|c|c|c|c|c|}
\hline Breach Name & Flow (cfs) & Flow $(\mathrm{cfs})^{\mathrm{a}}$ & Flow $(\mathrm{cfs})^{\mathrm{b}}$ & (cfs) & $(\mathrm{cfs})^{\mathrm{c}}$ & Notes \\
\hline \multicolumn{7}{|c|}{ Johnson Bottom } \\
\hline JB-OUT-1 & 13,600 & 16,100 & $13,000^{f}$ & $-2,500$ & +600 & $\begin{array}{l}\text { Flow entry to wetland is controlled by gate that is located at the } \\
\text { end of a connection channel. Very narrow breach was packed } \\
\text { sand. Channel thickly overgrown with willow and sedges. Highest } \\
\text { channel cross-section just past breach. Channel modified in } 2015 \\
\text { prior to spring peak to enhance connection to the river. } \\
\text { Observations during } 2015 \text { peak flows indicated connection now } \\
\text { occurs at }<10,000 \text { cfs. }\end{array}$ \\
\hline JB-OUT-2 & 14,100 & 16,400 & $13,000^{\mathrm{e}}$ & $-2,300$ & $+1,100$ & $\begin{array}{l}\text { Broad sand breach approximately same height as levee with } \\
\text { Russian olive, tamarisk, and annuals; sand road runs length of } \\
\text { breach. Broad channel slopes downward from breach to wetland. } \\
\text { Highest channel cross-section just past the breach. Breach } \\
\text { modified in } 2015 \text { prior to spring peak to enhance connection to the } \\
\text { river. JB-OUT was taking on water slowly on June 6, } 2014 \text { at } \\
16,700 \text { cfs. }\end{array}$ \\
\hline
\end{tabular}

\section{Leota Bottom}

LB7-IN

14,500

17,600

Not surveyed

$-3,100$

Not available

LB7A-IN
12,700
Not surveyed
Not available
13,400
$-700$
Sand road runs length of wide breach. Large deposit of sand in wetland from 2011 now mostly vegetated. Broad channel slopes downward from breach to wetland. Large sandbar at mouth of breach extends far into river. Highest channel cross-section at breach. Leota Bottom was almost full on June 5, 2014, with two active breaches (17,400 cfs); connected and draining on June 13, 2014 (14,700 cfs).

Not available Portion of breach is concrete; sand road runs length of breach. Large deposit of sand in wetland from 2011 now mostly vegetated. Broad channel slopes downward from breach to wetland. Highest channel cross-section at breach. Leota Bottom was almost full on June 5, 2014 with two active breaches (17,400 cfs); connected and draining on June 13, 2014 (14,700 cfs). 
Table 3 (Cont.)

\begin{tabular}{ccccccc}
$\begin{array}{c}\text { Floodplain } \\
\text { Wetland and } \\
\text { Breach Name }\end{array}$ & $\begin{array}{c}2014 \\
\text { Connection }\end{array}$ & $\begin{array}{c}2012 \\
\text { Connection }\end{array}$ & $\begin{array}{c}2005 \\
\text { Connection }\end{array}$ & $\begin{array}{c}\text { Change from } \\
2012 \text { to 2014 } \\
\text { (cfs) }\end{array}$ & $\begin{array}{c}\text { Change from } \\
2005 \text { to 2014 } \\
\text { (cfs) }\end{array}$ & Notes \\
\hline $\begin{array}{c}\text { Mean for all } \\
\text { Breaches }\end{array}$ & 16,318 & 16,772 & 13,091 & -971 & $+3,536$ & \\
\hline
\end{tabular}

a Values reported in LaGory et al. (2016).

b Values reported in Tetra Tech (2005) except where noted. 2005 connection flows are the flows that were targeted for connection when levee breaches were constructed. Tetra Tech (2005) made observations during the peak runoff period of 2005 to determine if connection was actually occurring at these flows by visiting sites at the following flows: Escalante Ranch: <10,000 cfs, 14,000 cfs, 16,700 cfs, and 19,600 cfs; Bonanza Bridge: <10,000 cfs, 13,900 cfs, 18,500 cfs, and 19,700 cfs; Stirrup: $<10,000 \mathrm{cfs}, 13,900 \mathrm{cfs}, 18,500 \mathrm{cfs}$, and 21,600 cfs; and Above Brennan: <10,000 cfs, 15,000 cfs, 18,300 cfs, and 21,800 cfs. These visits allowed verification of target flows. In some cases (as noted), actual connection flows were higher than the target.

d Comparisons of 2014 connection flows were made to actual estimates of connection in 2005 as reported in Tetra Tech (2005) where available.

e ER-IN-1 and ER-IN-2 were not surveyed because they had been intentionally filled to prevent connection.

f Estimated connection flows in 2012 and 2014 were compared to Bestgen (2011) because target connection value (13,000 cfs for both breaches) was not presented in Tetra Tech (2005). 
TABLE 4 Minimum Connection Flows at Floodplain Wetlands in 2005, 2012, and 2014 for Any Breach, Upstream Breaches, and Downstream Breaches ${ }^{a}$

\begin{tabular}{|c|c|c|c|c|c|c|}
\hline $\begin{array}{l}\text { Floodplain } \\
\text { Wetland }\end{array}$ & $\begin{array}{c}2005 \\
\text { Connection } \\
\text { Flow }(\mathrm{cfs})^{\mathrm{b}}\end{array}$ & $\begin{array}{c}2012 \\
\text { Connection } \\
\text { Flow (cfs) }\end{array}$ & $\begin{array}{c}2014 \\
\text { Connection } \\
\text { flow (cfs) }\end{array}$ & $\begin{array}{l}\text { Change from } \\
2005 \text { to } 2012 \\
\text { (cfs) }^{\mathrm{b}}\end{array}$ & $\begin{array}{l}\text { Change from } \\
2012 \text { to } 2014 \\
\text { (cfs) }\end{array}$ & $\begin{array}{c}\text { Change from } \\
2005 \text { to } 2014 \\
\text { (cfs) }\end{array}$ \\
\hline \multicolumn{7}{|c|}{ Minimum Connection Flows of Any Breach } \\
\hline $\begin{array}{l}\text { Escalante } \\
\text { Ranch }\end{array}$ & $\begin{array}{c}11,166 \\
(\text { ER-IN-6) }\end{array}$ & $\begin{array}{c}11,300 \\
\text { (ER-OUT) }\end{array}$ & $\begin{array}{c}\text { 8,740 } \\
\text { (ER-OUT) }\end{array}$ & +134 & $-2,560$ & $-2,426$ \\
\hline $\begin{array}{l}\text { Bonanza } \\
\text { Bridge }\end{array}$ & $\begin{array}{c}13,000 \\
(\mathrm{BB}-\mathrm{IN}-3)\end{array}$ & $\begin{array}{c}17,400 \\
\text { (BB-OUT) }\end{array}$ & $\begin{array}{c}14,900 \\
\text { (BB-OUT) }\end{array}$ & $+4,400$ & $-2,500$ & $+1,900$ \\
\hline Stirrup & $\begin{array}{c}13,000 \\
\text { (ST-OUT) }\end{array}$ & $\begin{array}{c}16,900 \\
\text { (ST-OUT) }\end{array}$ & $\begin{array}{c}15,700 \\
\text { (ST-OUT) }\end{array}$ & $+3,900$ & $-1,200$ & $+2,700$ \\
\hline $\begin{array}{l}\text { Above } \\
\text { Brennan }\end{array}$ & $\begin{array}{c}13,000 \\
\text { (all breaches) }\end{array}$ & $\begin{array}{c}9,990 \\
\text { (AB-OUT) }\end{array}$ & $\begin{array}{c}10,400 \\
\text { (AB-OUT) }\end{array}$ & $-3,010$ & +410 & $-2,600$ \\
\hline $\begin{array}{l}\text { Johnson } \\
\text { Bottom }\end{array}$ & $\begin{array}{c}13,000 \\
\text { (all breaches) }\end{array}$ & $\begin{array}{c}16,100 \\
\text { (JB-OUT-1) }\end{array}$ & $\begin{array}{c}13,600 \\
\text { (JB-OUT-1) }\end{array}$ & $+3,100$ & $-2,500$ & +600 \\
\hline Leota Bottom & $\mathrm{NA}^{\mathrm{c}}$ & $\begin{array}{c}13,400 \\
\text { (LB7A-IN) }\end{array}$ & $\begin{array}{c}12,700 \\
\text { (LB7A-IN) }\end{array}$ & NA & -700 & NA \\
\hline Mean & 12,633 & $\begin{array}{c}14,182 \\
(14,338)^{\mathrm{c}}\end{array}$ & $\begin{array}{c}12,673 \\
(12,668)^{\mathrm{c}}\end{array}$ & $+1,705$ & $-1,508$ & +35 \\
\hline \multicolumn{7}{|c|}{ Minimum Connection Flow of Upstream Breaches } \\
\hline $\begin{array}{l}\text { Escalante } \\
\text { Ranch }\end{array}$ & $\begin{array}{c}11,166 \\
(\mathrm{ER}-\mathrm{IN}-6)\end{array}$ & $\begin{array}{c}15,300 \\
(\text { ER-IN-7) }\end{array}$ & $\begin{array}{c}17,600 \\
\text { (ER-IN-7) }\end{array}$ & $+4,134$ & $+2,300$ & $+6,434$ \\
\hline $\begin{array}{l}\text { Bonanza } \\
\text { Bridge }\end{array}$ & $\begin{array}{c}13,000 \\
(\mathrm{BB}-\mathrm{IN}-3)\end{array}$ & $\begin{array}{c}20,100 \\
(\mathrm{BB}-\mathrm{IN}-1)\end{array}$ & $\begin{array}{c}19,800 \\
(\mathrm{BB}-\mathrm{IN}-1)\end{array}$ & $+7,100$ & -300 & $+6,800$ \\
\hline $\begin{array}{l}\text { Above } \\
\text { Brennan }\end{array}$ & $\begin{array}{c}13,000 \\
\text { (all breaches) }\end{array}$ & $\begin{array}{c}16,400 \\
\text { (AB-IN-1) }\end{array}$ & $\begin{array}{c}14,600 \\
(\mathrm{AB}-\mathrm{IN}-3)\end{array}$ & $+3,400$ & $-1,800$ & $+1,600$ \\
\hline Mean & 12,389 & 17,267 & 17,333 & $+4,878$ & -67 & $+4,945$ \\
\hline \multicolumn{7}{|c|}{ Minimum Connection Flow of Downstream Breaches } \\
\hline $\begin{array}{l}\text { Escalante } \\
\text { Ranch }\end{array}$ & $\begin{array}{c}12,433 \\
\text { (ER-OUT) }\end{array}$ & $\begin{array}{c}11,300 \\
\text { (ER-OUT) }\end{array}$ & $\begin{array}{c}8,740 \\
\text { (ER-OUT) }\end{array}$ & $-1,133$ & $-2,560$ & $-3,693$ \\
\hline $\begin{array}{l}\text { Bonanza } \\
\text { Bridge }\end{array}$ & $\begin{array}{c}13,900 \\
\text { (BB-OUT) }\end{array}$ & $\begin{array}{c}17,400 \\
\text { (BB-OUT) }\end{array}$ & $\begin{array}{c}14,900 \\
\text { (BB-OUT) }\end{array}$ & $+3,500$ & $-2,500$ & $+1,000$ \\
\hline Stirrup & $\begin{array}{c}13,000 \\
\text { (ST-OUT) }\end{array}$ & $\begin{array}{c}16,900 \\
\text { (ST-OUT) }\end{array}$ & $\begin{array}{c}15,700 \\
\text { (ST-OUT) }\end{array}$ & $+3,900$ & $-1,200$ & $+2,700$ \\
\hline $\begin{array}{l}\text { Above } \\
\text { Brennan }\end{array}$ & $\begin{array}{c}13,000 \\
\text { (AB-OUT) }\end{array}$ & $\begin{array}{c}\text { 9,990 } \\
\text { (AB-OUT) }\end{array}$ & $\begin{array}{c}10,400 \\
\text { (AB-OUT) }\end{array}$ & $-3,010$ & +410 & $-2,600$ \\
\hline $\begin{array}{l}\text { Johnson } \\
\text { Bottom }\end{array}$ & $\begin{array}{c}13,000 \\
\text { (all breaches) }\end{array}$ & $\begin{array}{c}16,100 \\
\text { (JB-OUT-1) }\end{array}$ & $\begin{array}{c}13,600 \\
\text { (JB-OUT-1) }\end{array}$ & $+3,100$ & $-2,500$ & +600 \\
\hline Leota Bottom & $\mathrm{NA}^{\mathrm{b}}$ & $\begin{array}{c}13,400 \\
\text { (LB7A-IN) }\end{array}$ & $\begin{array}{c}12,700 \\
\text { (LB7A-IN) }\end{array}$ & NA & -700 & NA \\
\hline Mean & 13,067 & $\begin{array}{c}14,182 \\
(14,338)^{d}\end{array}$ & $\begin{array}{c}12,673 \\
(12,668)^{d}\end{array}$ & $+1,271$ & $-1,508$ & -399 \\
\hline
\end{tabular}




\section{Table 4 (Cont.)}

a Breaches associated with connection flows are presented in parentheses

b 2005 connection flows are from Tetra Tech (2005) for all wetlands except for Johnson Bottom, which are from Bestgen et al. (2011). When 2005 target connection flows were known to be incorrect (based on Tetra Tech 2005 observations noted in Table 3), comparisons were made to observed connection flows.

c $\quad$ NA = not available because connection flow for Leota Bottom was not reported for 2005.

d Value in parentheses represents the mean of flows without Leota Bottom to enable comparison with the 2005 mean. 
TABLE 5 Fish Passage Flows ${ }^{\mathrm{a}}$ at Surveyed Breaches in 2005, 2012, and 2014

\begin{tabular}{|c|c|c|c|c|c|c|}
\hline $\begin{array}{c}\text { Floodplain } \\
\text { Wetland/ } \\
\text { Breach Name }\end{array}$ & $\begin{array}{c}2005 \text { Fish } \\
\text { Passage Flow } \\
(\mathrm{cfs})^{\mathrm{b}}\end{array}$ & $\begin{array}{c}2012 \text { Fish } \\
\text { Passage Flow } \\
(\mathrm{cfs})\end{array}$ & $\begin{array}{c}2014 \text { Fish } \\
\text { Passage Flow } \\
\text { (cfs) }\end{array}$ & $\begin{array}{c}\text { Change from } \\
2005 \text { to } 2012 \\
\text { (cfs) }\end{array}$ & $\begin{array}{c}\text { Change from } \\
2012 \text { to } 2014 \\
\text { (cfs) }\end{array}$ & $\begin{array}{c}\text { Change from } \\
2005 \text { to } 2014 \\
\text { (cfs) }\end{array}$ \\
\hline \multicolumn{7}{|l|}{ Escalante Ranch } \\
\hline ER-IN-3 & 15,100 & 21,500 & 21,400 & $+6,400$ & -100 & $+6,300$ \\
\hline ER-IN-4 & 16,200 & 23,900 & 23,400 & $+7,700$ & -500 & $+7,200$ \\
\hline ER-IN-5 & 15,200 & 20,100 & 22,800 & $+4,900$ & $+2,700$ & $+7,600$ \\
\hline ER-IN-6 & 14,200 & 22,600 & 22,200 & $+8,400$ & -400 & $+8,000$ \\
\hline ER-IN-7 & 15,200 & 18,500 & 20,900 & $+3,300$ & $+2,400$ & $+5,700$ \\
\hline ER-OUT & 15,600 & 14,300 & 11,500 & $-1,300$ & $-2,800$ & $-4,100$ \\
\hline \multicolumn{7}{|l|}{ Bonanza Bridge } \\
\hline BB-IN-1 & 22,300 & 23,700 & 23,200 & $+1,400$ & -500 & +900 \\
\hline BB-IN-2 & 17,300 & 24,700 & 23,900 & $+7,400$ & -800 & $+6,600$ \\
\hline BB-IN-3 & 16,300 & 27,900 & 25,700 & $+11,600$ & $-2,200$ & $+9,400$ \\
\hline BB-OUT & 17,300 & 20,800 & 18,100 & $+3,500$ & $-2,700$ & +800 \\
\hline \multicolumn{7}{|l|}{ Stirrup } \\
\hline ST-OUT & 16,300 & 20,200 & 19,000 & $+3,900$ & $-1,200$ & $+2,700$ \\
\hline \multicolumn{7}{|l|}{ Above } \\
\hline \multicolumn{7}{|l|}{ Brennan } \\
\hline AB-IN-1 & 16,300 & 19,700 & 18,400 & $+3,400$ & $-1,300$ & $+2,100$ \\
\hline AB-IN-2 & 16,300 & 23,000 & 22,500 & $+6,700$ & -500 & $+6,200$ \\
\hline AB-IN-3 & 16,300 & 21,900 & 17,700 & $+5,600$ & $-4,200$ & $+1,400$ \\
\hline AB-OUT & 16,300 & 13,000 & 13,300 & $-3,300$ & +300 & $-3,000$ \\
\hline \multicolumn{7}{|l|}{ Johnson Bottom } \\
\hline JB-OUT-1 & 15,400 & 18,700 & 16,000 & $+3,300$ & $-2,700$ & +600 \\
\hline JB-OUT-2 & 15,400 & 19,000 & 16,500 & $+3,600$ & $-2,500$ & $+1,100$ \\
\hline \multicolumn{7}{|l|}{ Leota Bottom } \\
\hline LB7-IN & $\mathrm{NA}^{\mathrm{c}}$ & 20,300 & 17,000 & NA & $-3,300$ & NA \\
\hline LB7A-IN & NA & 15,800 & 15,100 & NA & -700 & NA \\
\hline Mean & 16,294 & $\begin{array}{c}20,505 \\
(20,794)^{\mathrm{d}}\end{array}$ & $\begin{array}{c}19,400 \\
(19,794)\end{array}$ & $+4,500$ & $-1,105$ & $+3,500$ \\
\hline
\end{tabular}

a Based on minimum fish passage depth of $1 \mathrm{ft}$ reported in Burdick (1997).

b Fish passage flows for 2005 were estimated by the authors using the elevations associated with reported 2005 connection flows in Tetra Tech (2005) and Bestgen et al. (2011), adding $1 \mathrm{ft}$ to the elevation, and determining the associated flow in the stage-flow table provided by USGS for 2005. Since the Ouray gage was not in place in 2005, we used the 2012 stage flow table for the Ouray gage to estimate fish passage flows for Johnson Bottom and Leota Bottom in that year.

c $\quad \mathrm{NA}=$ not available.

d Value in parentheses represents the mean of flows without Leota Bottom to enable comparison with the 2005 mean. 
- Fish passage elevation (flow): minimum water surface elevation and associated flow that would provide at least $1 \mathrm{ft}(30 \mathrm{~cm})$ of depth along the entire connection channel. This is considered to be the minimum depth that would allow subadult and adult razorback suckers to swim between the wetland and river (Burdick 1997).

\subsection{ESCALANTE RANCH}

The Escalante Ranch wetland, formerly known as Thunder Ranch, was surveyed on October 27, 2014. The local flow at Escalante Ranch at the time of the survey was estimated to be 2,630 cfs (Table 2).

Six locations were surveyed at Escalante Ranch: five upstream breaches and one downstream breach (Figure 3). Two additional former upstream breaches are present at Escalante Ranch (ER-IN-1 and ER-IN-2). These breaches were not surveyed in 2014 because they had been intentionally filled with rip-rap and no longer served as inlets except at flows higher than 22,000 cfs (LaGory et al. 2016). Characterization of levee breaches and connection channel elevations at each of the surveyed locations is provided below.

The 2014 minimum connection flow at Escalante Ranch occurred at the downstream breach (ER-OUT), and was estimated to be 8,740 cfs, which was approximately 2,560 cfs and 2,426 cfs lower than the minimum connection flow estimates made in 2012 and 2005, respectively (Table 4). In 2014, the estimated minimum upstream breach connection flow was 17,600 cfs (ER-IN-7), which was 2,300 cfs and 6,434 cfs higher than the estimated minimum upstream connection flow in 2012 and 2005, respectively. In 2014, the estimated minimum downstream breach connection flow was 8,740 cfs (ER-OUT), which was 2,560 cfs and 3,693 cfs lower than the estimated minimum downstream connection flow in 2012 and 2005, respectively. Estimated minimum fish passage flows for Escalante Ranch showed the same pattern as connection flows, but were on average 3,243 cfs higher than connection flows (Table 5).

On April 29, 2014, USFWS field staff observed connection of the Escalante Ranch wetland with the Green River main channel, and, at this time, the wetland was draining to the river (T. Jones, USFWS, personal communication); flow at the Jensen gage on this day averaged 9,090 cfs. The maximum flow prior to this date was 9,910 cfs on April 25 when the river apparently first connected. On June 13, 2014, USFWS noted that the floodplain was draining and appeared to be equalizing with the Green River stage level; flow at the Jensen gage on this day averaged 15,500 cfs. Connection was also reported in 2013 when the peak flow was 11,000 cfs.

ER-IN-3. A total of 235 locations were surveyed at ER-IN-3 in 2014. The estimated mean river water surface elevation near ER-IN-3 was 4,733.6 ft. ER-IN-3 was a well-defined sandy breach with some Russian thistle growing in the breach. The breach was approximately $6 \mathrm{ft}(2 \mathrm{~m})$ deeper than the levee, and some erosion and slumping of the breach and levee edge were observed. The sand road intersecting the floodplain connection channel was higher than the 


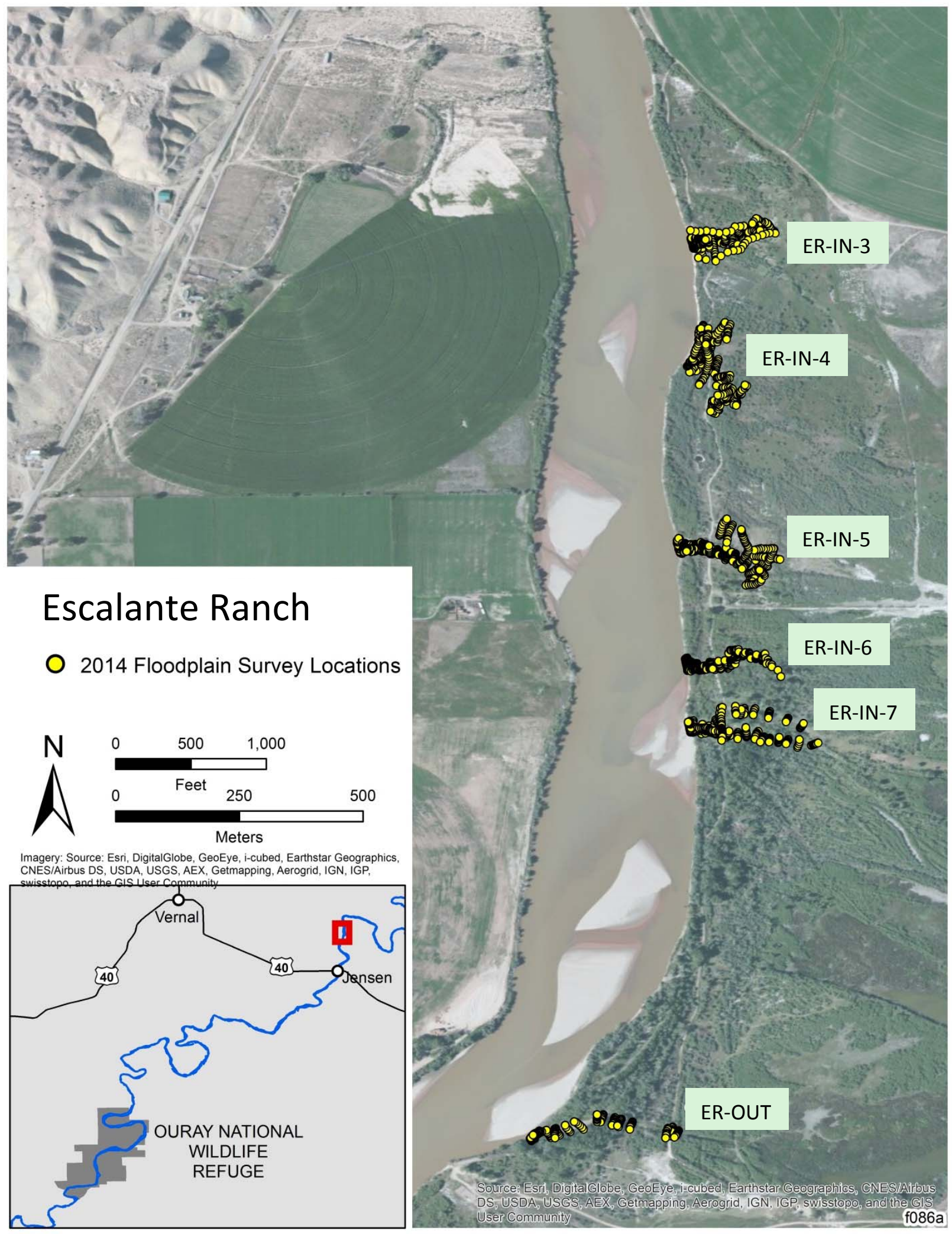

FIGURE 3 Escalante Ranch Survey Locations in 2014. The date of the aerial imagery differs from the date of the survey; aerial imagery does not depict exact conditions at the time of the survey. 
breach near the river edge. Based on our 2014 survey, the connection flow was 18,100 cfs (Table 3), and the highest channel cross-section was about two-thirds of the way between the breach and the wetland (Figure B-1). The 2014 estimated connection flow is the same as that recorded in 2012, and 6,200 cfs higher than in 2005. Estimated fish passage flow for ER-IN-3 in 2014 was 21,400 cfs, which is 100 cfs lower than in 2012 (Table 5).

ER-IN-4. A total of 364 locations were surveyed at ER-IN-4 in 2014. The estimated mean river water surface elevation near ER-IN-4 was 4,733.2 ft. At the time of the survey, ERIN-4 was completely filled with sand with no apparent cut in the levee. The sand road crossing the channel between the breach and wetland was higher than the breach. Based on our 2014 survey, the connection flow for ER-IN-4 was 20,000 cfs (Table 3), and the highest channel crosssection was near the wetland edge (Figure B-2). The 2014 estimated connection flow is $300 \mathrm{cfs}$ lower than in 2012 and 7,067 cfs higher than in 2005. Estimated fish passage flow for ER-IN-4 in 2014 was 23,400 cfs, which is 500 cfs lower than in 2012 (Table 5).

ER-IN-5. A total of 393 locations were surveyed at ER-IN-5 in 2014. The estimated mean river water surface elevation at ER-IN-5 was 4,733.0 ft. At the time of the survey, ER-IN-5 was a shallow breach (approximately $3 \mathrm{ft}$ [1 m] in depth) of loose sand. Based on our 2014 survey, the connection flow for ER-IN-5 was 19,400 cfs (Table 3), and the highest channel crosssection was near the wetland edge (Figure B-3). The 2014 estimated connection flow is 2,600 cfs higher than in 2012 and 7,400 cfs higher than in 2005. Estimated fish passage flow for ER-IN-5 in 2014 was 22,800 cfs, which is 2,700 cfs higher than in 2012 (Table 5).

ER-IN-6. A total of 249 locations were surveyed at ER-IN-6 in 2014. The estimated mean river water surface elevation at ER-IN-6 was 4,732.8 ft. At the time of the survey, ER-IN-6 was a shallow breach (approximately $3 \mathrm{ft}$ [1 m] in depth) of loose sand. Based on our 2014 survey, the connection flow for ER-IN-6 was 18,900 cfs (Table 3), and the highest channel cross-section was near the road on the wetland side (Figure B-4). The 2014 estimated connection flow is 300 cfs lower than in 2012 and a 7,734 cfs higher than in 2005. Estimated fish passage flow for ER-IN-6 in 2014 was 22,200 cfs, which is 400 cfs lower than in 2012.

ER-IN-7. A total of 248 locations were surveyed at ER-IN-7 in 2014. The estimated mean river water surface elevation at ER-IN-7 was 4,732.7 ft. At the time of the survey, ER-IN-7 was a broad, low, sandy breach, which was filled with sand to the height of the levee. New sand deposits were observed between the river and the sand road. Based on our 2014 survey, the connection flow for ER-IN-7 was 17,600 cfs (Table 3), and the highest channel cross-section was near the breach (Figure B-5). The 2014 estimated connection flow is 2,300 cfs higher than in 2012 and 5,600 cfs lower than in 2005. Estimated fish passage flow for ER-IN-7 in 2014 was 20,900 cfs, which is 2,400 cfs higher than in 2012 (Table 5).

ER-OUT. A total of 150 locations were surveyed at ER-OUT in 2014. The estimated mean river water surface elevation at ER-OUT was 4,731.8 $\mathrm{ft}$. At the time of the survey, EROUT was a long broad channel extending from the river to the wetland. Hard-packed sand in the channel near the river and breach showed signs of scour. There was a scour hole with standing water (as observed in 2012) located midway up the channel toward the wetland. Other areas of standing water in the channel supported well-developed wetland vegetation (mostly sedges). A gravel road crossed the channel near the wetland. Based on our 2014 survey, the connection flow 
for ER-OUT was 8,740 cfs (Table 3), and the highest channel cross-section was half way between the breach and the wetland (Figure B-6). The 2014 estimated connection flow is 2,560 cfs lower than in 2012 and 3,693 cfs higher than in 2005. Estimated fish passage flow for EROUT in 2014 was 11,500 cfs, which is 2,800 cfs lower than in 2012 (Table 5).

\subsection{BONANZA BRIDGE}

The Bonanza Bridge wetland was surveyed on October 29, 2014. The local flow at Bonanza Bridge at the time of the survey was estimated to be 2,215 cfs (Table 2).

Four locations were surveyed at Bonanza Bridge: three upstream breaches and one downstream breach (Figure 4). Characterization of levee breaches and connection channel elevations at each of these locations is provided below. The 2014 minimum connection flow at Bonanza Bridge occurred at the downstream breach (BB-OUT), and was estimated to be $14,900 \mathrm{cfs}$, which was 2,500 cfs lower and 1,900 cfs higher than the minimum connection flow estimates made in 2012 and 2005, respectively (Table 4). In 2014, the estimated minimum upstream breach connection flow was 19,800 cfs (BB-IN-1), which was $300 \mathrm{cfs}$ lower and 6,800 cfs higher than the estimated minimum upstream connection flow in 2012 and 2005, respectively. In 2014, the estimated minimum downstream breach connection flow was $14,900 \mathrm{cfs}$ (BB-OUT), which was 2,500 cfs lower and 1,000 cfs higher than the estimated minimum downstream connection flow in 2012 and 2005, respectively. Fish passage flow estimates for Bonanza Bridge showed the same pattern as connection flow, but were on average 3,600 cfs higher than connection flows (Table 5). 2014.

Observations of Bonanza Bridge connection during peak flows were not available for

BB-IN-1. A total of 436 locations were surveyed at BB-IN-1 in 2014. The estimated mean river water surface elevation at BB-IN-1 was 4,699.0 ft. At the time of the survey, BB-IN-1 was partially blocked with loose sand, and led to a well-defined vegetated channel. A sand access road crossed and partially blocked the connection channel near the breach. Another road crossed near the channel's midpoint and was slightly higher elevation than the channel. There was a very large deposit of sand at the wetland end of the channel that had been deposited during peak flows in 2008 and 2011 (LaGory et al. 2016). Based on our 2014 survey, the estimated connection flow for BB-IN-1 was 19,800 cfs (Table 3), and the highest channel crosssection was near the breach (Figure B-7). The 2014 connection flow is $300 \mathrm{cfs}$ lower than in 2012 and 1,300 cfs higher than in 2005. Estimated fish passage flow for BB-IN-1 in 2014 was 23,200 cfs, which is 500 cfs lower than in 2012 (Table 5).

BB-IN-2. A total of 425 locations were surveyed at BB-IN-2 in 2014. The estimated mean river water surface elevation at BB-IN-2 was 4,700.9 ft. At the time of the survey, BB-IN2 and its connection channel were mostly blocked with loose sand, and there was a very large deposit of sand at the wetland end of the channel that had been deposited during peak flows in 2008 and 2011 (LaGory et al. 2016). A sand road led to the breach and provided river access; the 


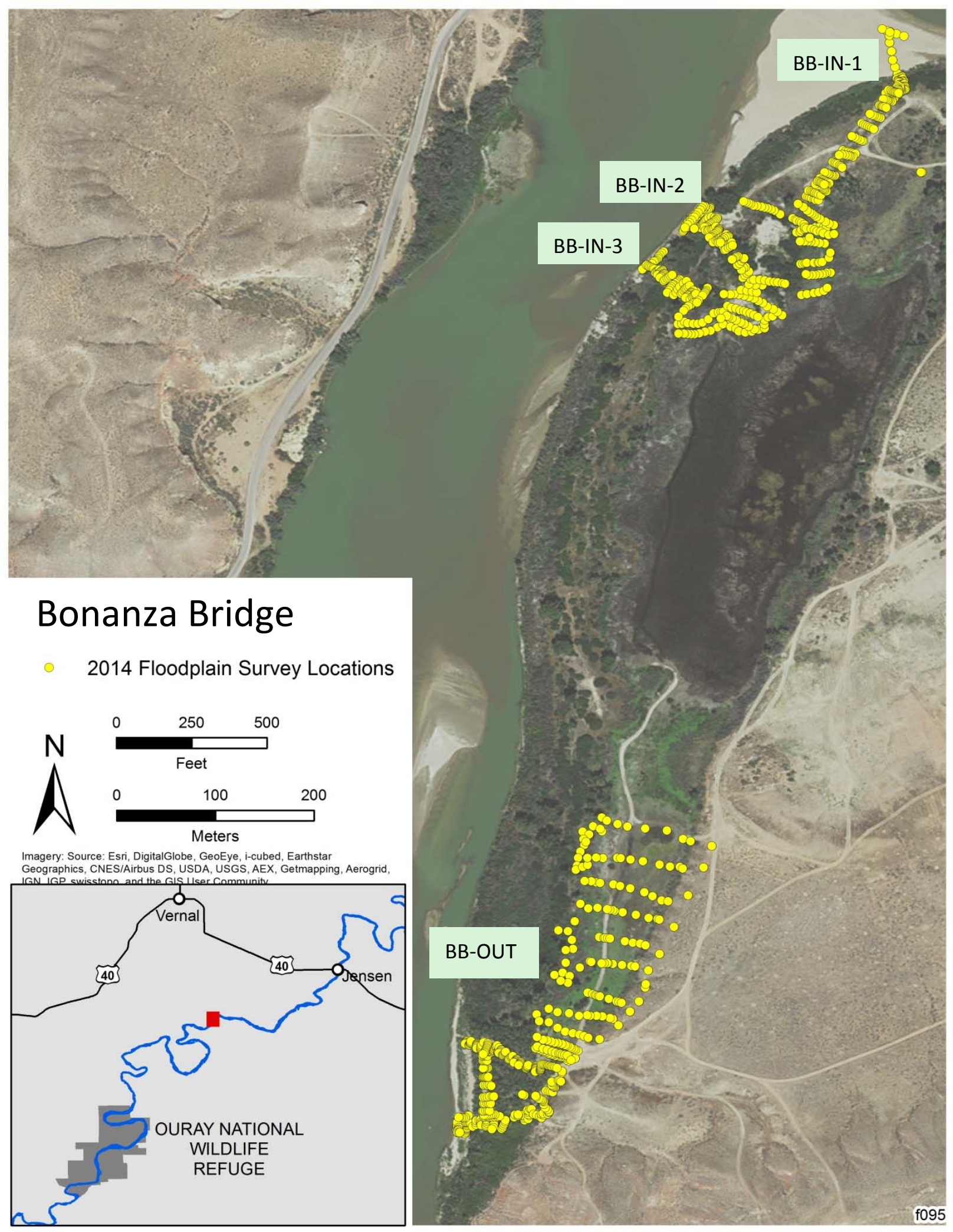

FIGURE 4 Bonanza Bridge Survey Locations in 2014. The date of the aerial imagery differs from the date of the survey; aerial imagery does not depict exact conditions at the time of the survey. 
road did not cross the connection channel. Based on our 2014 survey, the estimated connection flow for BB-IN-2 was 20,500 cfs (Table 3), and the highest channel cross-section was located halfway between the breach and wetland (Figure B-8). The 2014 connection flow is 600 cfs lower than in 2012 and 6,600 cfs higher than in 2005. Estimated fish passage flow for BB-IN-2 in 2014 was 23,900 cfs, which is 800 cfs lower than in 2012 (Table 5).

BB-IN-3. A total of 184 locations were surveyed at BB-IN-3 in 2014. The estimated mean river water surface elevation at BB-IN-3 was 4,699.9 ft. At the time of the survey, BB-IN3 was completely filled with loose sand. Although the breach contained sand deposits, the connection channel was relatively free of obstruction with the exception of some vegetation and cut brush. Based on our 2014 survey, the estimated connection flow for BB-IN-3 was 22,200 cfs (Table 3), and the highest channel cross-section was located near the breach (Figure B-9). The 2014 connection flow is 1,900 cfs lower than in 2012 and 9,200 cfs higher than in 2005. Estimated fish passage flow for BB-IN-3 in 2014 was 25,700 cfs, which is 2,200 cfs lower than in 2012 (Table 5).

BB-OUT. A total of 829 locations were surveyed at BB-OUT in 2014 (Figure 14). The estimated mean river water surface elevation near BB-OUT was 4,700.0 ft. BB-OUT consists of two breaches, but these were mostly filled with sand with no depression in elevation relative to the levees. The breaches lead to a network of unimproved dirt and gravel roads that serve as connection channels to the wetland through a broad low woodland. Based on our 2014 survey, the estimated connection flow at BB-OUT was 14,900 cfs (Table 3), and the highest channel cross-section was along an access road/channel halfway between the downstream breach and wetland (Figure B-10). The 2014 estimated connection flow is 2,500 cfs lower than in 2012 and 1,000 cfs higher than in 2005. Estimated minimum fish passage flow for BB-OUT in 2014 was 18,100 cfs, which is 2,700 cfs lower than in 2012 (Table 5).

\subsection{STIRRUP}

The Stirrup wetland was surveyed on October 28, 2014. The local flow at Stirrup at the time of the survey was estimated to be 2,705 cfs (Table 2).

There is only one breach location (downstream) at Stirrup (ST-OUT, Figure 5). A total of 220 locations were surveyed at ST-OUT in 2014. The estimated mean river water surface elevation at ST-OUT was 4,680.1 ft. At the time of the survey, ST-OUT was a narrow incised channel in the middle of a breach of packed sand and silt; the connection channel was narrow, but did not have any apparent obstructions to flow. Based on our 2014 survey, the minimum connection flows at ST-OUT was estimated to be 15,700 cfs (Table 3), and the highest channel cross-section was located just past the breach (Figure B-11). The 2014 connection flow is 1,200 cfs lower than in 2012 and 2,700 cfs higher than in 2005 (Table 4). Estimated minimum fish passage flow for ST-OUT in 2014 was 19,000 cfs, which is 1,200 cfs lower than in 2012 (Table 5). 


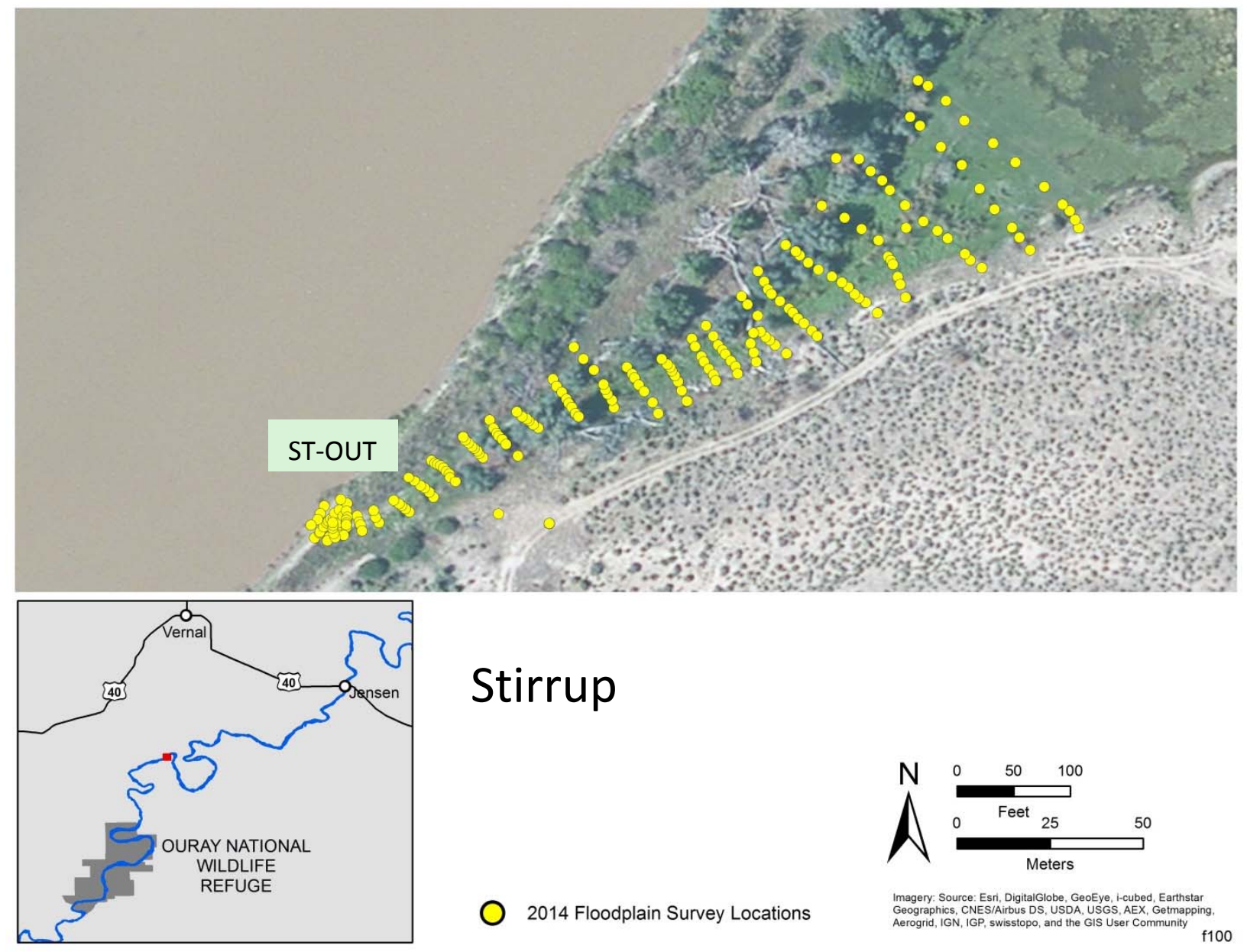

FIGURE 5 Stirrup Survey Locations in 2014. The date of the aerial imagery differs from the date of the survey; aerial imagery does not depict exact conditions at the time of the survey.

On June 4, 2014, USFWS personnel observed connection of the Stirrup wetland to the Green River main channel (T. Jones, USFWS, personal communication) at a flow of 18,600 cfs. On June 13, 2014, the water level in the Stirrup was observed to be equal to river flow $(15,500 \mathrm{cfs})$.

\subsection{ABOVE BRENNAN}

The Above Brennan wetland was surveyed on October 29, 2014. The local flow at Above Brennan at the time of the survey was estimated to be 2,525 cfs (Table 2).

Four breach locations were surveyed at Above Brennan in 2014: three upstream breaches and a downstream breach (Figure 6). Characterizations of levee breach and connection channel elevations at each of these locations are provided below. The 2014 minimum connection flow at 


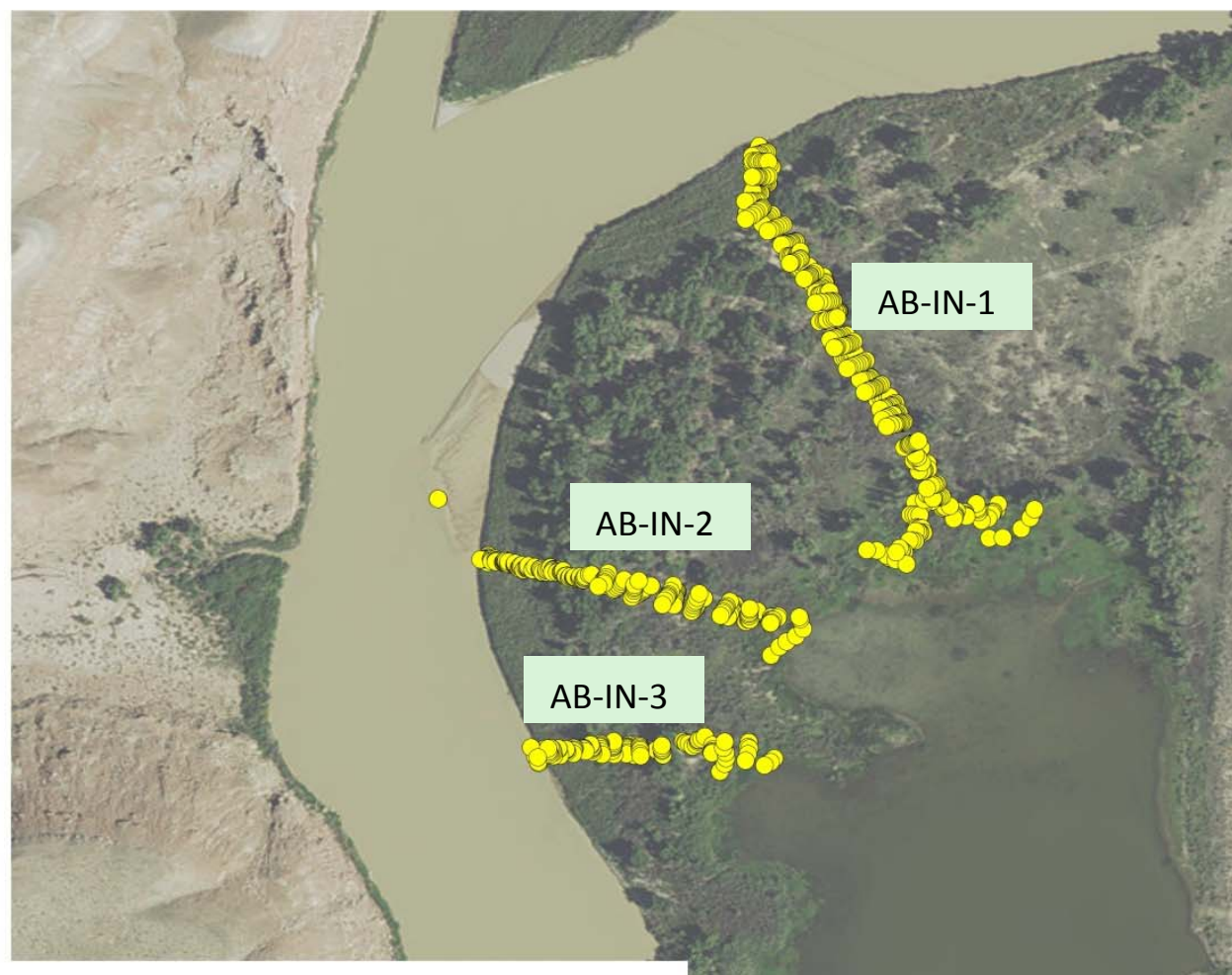

\section{Above Brennan}

2014 Floodplain Survey Locations

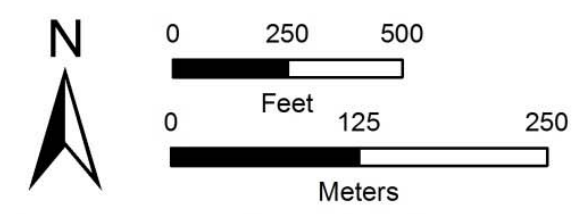

Imagery: Source: Esri, DigitalGlobe, GeoEye, i-cubed, Earthstar Geographics, CNES/Airbus DS, USDA, USGS, AEX, Getmapping, Aerogrid, IGN, IGP, swisstopo, and the GIS User Community
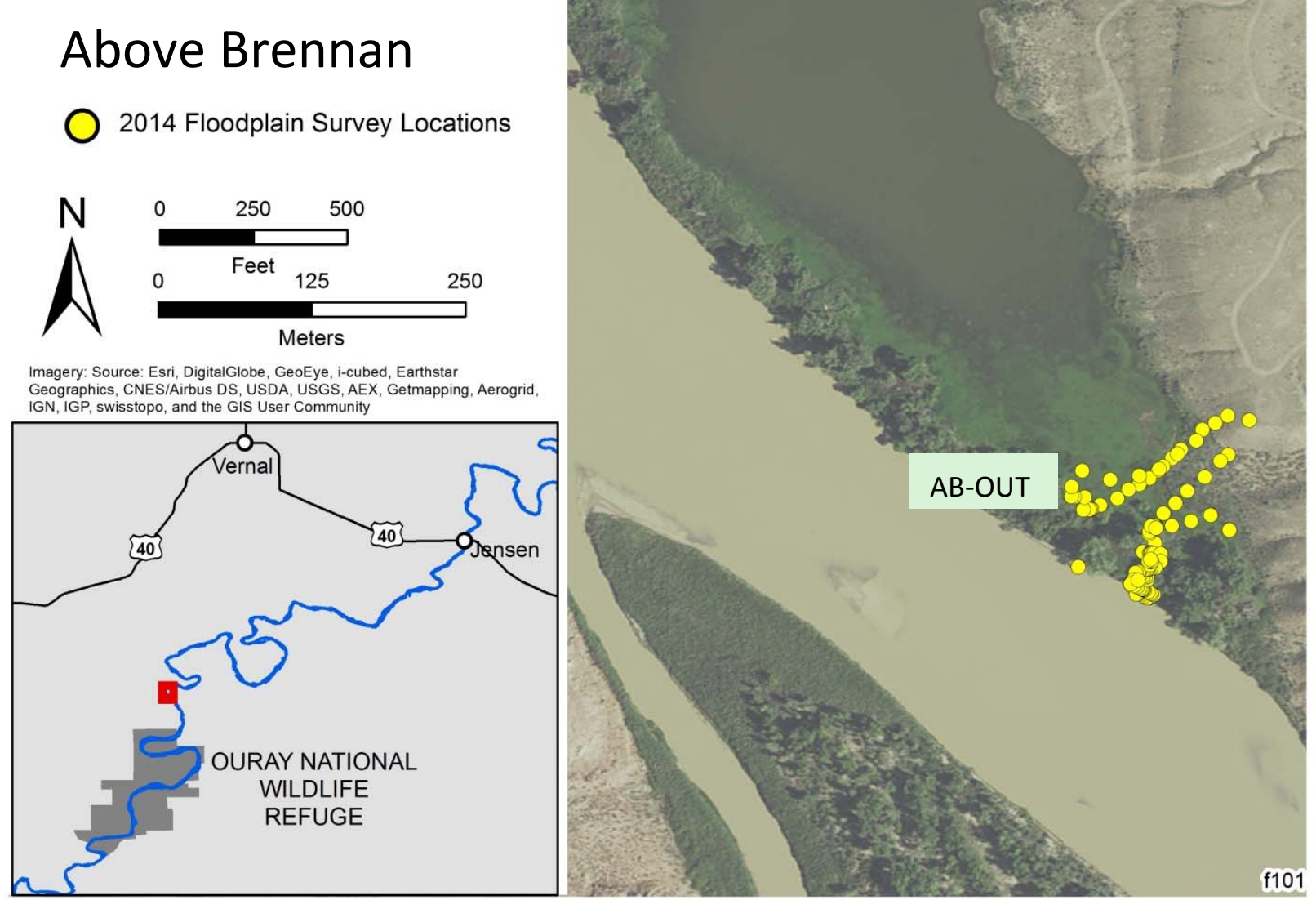

FIGURE 6 Above Brennan Survey Locations in 2014. The date of the aerial imagery differs from the date of the survey; aerial imagery does not depict exact conditions at the time of the survey. 
Above Brennan occurred at the downstream breach (AB-OUT), and was estimated to be 10,400 cfs, which was 410 cfs higher and 2,600 cfs lower than the minimum connection flow estimates made in 2012 and 2005, respectively (Table 4). In 2014, the estimated minimum upstream breach connection flow was $14,600 \mathrm{cfs}$ (AB-IN-3), which is 1,800 cfs lower and 1,600 cfs higher than the minimum upstream connection flow in 2012 and 2005, respectively. Fish passage flow estimates for Above Brennan showed the same pattern as connection flow, but were on average 3,300 cfs higher (Table 5).

On June 4, 2014, USFWS observed connection of the Above Brennan wetland with at least two upstream breaches connected to the Green River main channel (T. Jones, USFWS, personal communication) at 18,600 cfs. River water was still flowing into upstream breaches on June 13, 2014 when flow at the Jensen gage was 15,500 cfs.

AB-IN-1. A total of 647 locations were surveyed at AB-IN-1 in 2014. The estimated mean river water surface elevation at AB-IN-1 was 4,671.5 ft. At the time of the survey, AB-IN1 was nearly filled with loose sand; elevation along the connection channel sloped downward from the breach to the floodplain wetland. Based on our 2014 survey, the estimated connection flow at AB-IN-1 was 15,200 cfs (Table 3), and the highest channel cross-section was located just past the breach (Figure B-12). The 2014 connection flow was 1,200 cfs lower than in 2012 and 2,200 cfs higher than in 2005. Estimated fish passage flow for AB-IN-1 in 2014 was 18,400 cfs, which is 1,300 cfs lower than in 2012 (Table 5).

AB-IN-2. A total of 518 locations were surveyed at AB-IN-2 in 2014. The estimated mean river water surface elevation at AB-IN-2 was 4,671.1 ft. At the time of the survey, AB-IN2 was a narrow cut through packed sand and silt with no apparent signs of erosion or deposition. The connection channel was narrow (approximately $3 \mathrm{ft}$ [1 m] wide), and passed through a dense willow thicket before opening into a wide channel with less vegetation. Based on our 2014 survey, the estimated connection flow for AB-IN-2 was 19,100 cfs (Table 3), and the highest channel cross-section was approximately one fourth of the distance between the breach and the wetland (Figure B-13). The 2014 connection flow was $400 \mathrm{cfs}$ lower than in 2012 and 6,100 cfs higher than in 2005. Estimated fish passage flow for AB-IN-2 in 2014 was 22,500 cfs, which is 500 cfs lower than in 2012 (Table 5).

AB-IN-3. A total of 122 locations were surveyed at AB-IN-3 in 2014. The estimated mean river water surface elevation at AB-IN-3 was 4,671.0 ft. At the time of the survey, AB-IN3 was a narrow cut through packed sand and silt with no apparent signs of erosion or deposition. The connection channel was narrow (approximately $3 \mathrm{ft}$ [1 m] wide), and passed through a dense willow thicket before opening into a wide channel with less vegetation. Based on our 2014 survey, the estimated connection flow for AB-IN-3 was 14,600 cfs (Table 3), and the highest channel cross-section was just past the breach (Figure B-14). The 2014 connection flow was 3,900 cfs lower than in 2012 and 1,600 cfs higher than in 2005. Estimated fish passage flow for AB-IN-3 in 2014 was 17,700 cfs, which was 4,200 cfs lower than in 2012 (Table 5).

AB-OUT. A total of 121 locations were surveyed at AB-OUT in 2014. The estimated mean river water surface elevation at $\mathrm{AB}-\mathrm{OUT}$ was $4,670.7 \mathrm{ft}$. At the time of the survey, ABOUT was a narrow incised channel through a broad mud breach, with a wide connection channel 
that was vegetated with grasses. An old beaver dam and large tree trunks that cross the channel could obstruct flow, but there were no sand deposits observed in the connection channel. Based on our 2014 survey, the estimated minimum connection flow for AB-OUT was 10,400 cfs (Table 3), and the highest channel cross-section was two-thirds of the way between the breach and the wetland (Figure B-15). The 2014 connection flow was 410 cfs higher than in 2012 and 2,600 cfs lower than in 2005. Estimated fish passage flow for AB-OUT in 2014 was 13,300 cfs, which was 300 cfs higher than in 2012.

\subsection{JOHNSON BOTTOM}

The Johnson Bottom wetland was surveyed on October 30, 2014. The local flow at Johnson Bottom at the time of the survey was calculated to be 2,170 cfs (Table 2).

Two downstream breach locations were surveyed at Johnson Bottom (Figure 7). Characterizations of levee breach and connection channel elevations at each of these locations are provided below. The 2014 estimated minimum connection flow at Johnson Bottom was 13,600 cfs (JB-OUT-1), which was about 2,500 cfs lower than in 2012 and $600 \mathrm{cfs}$ higher than the value reported in Bestgen et al. (2011) (Table 4). Fish passage flow estimates for Johnson Bottom showed the same pattern as connection flow, but were on average 2,400 cfs higher (Table 5).

Both JB-OUT-1 and JB-OUT-2 were modified in 2015 prior to the spring peak to enhance connection to the river. Observations during the 2015 peak flow indicated connection at JB-IN-1 occurred at flows lower than 10,000 cfs. JB-OUT-2 was taking on water slowly on June 6, 2014 when flows at the Ouray gage were 16,700 cfs.

JB-OUT-1. JB-OUT-1 is a concrete and metal gated drain structure and fish kettle that was constructed in 1999 (Heitmeyer and Fredrickson 2005). A total of 324 locations were surveyed at JB-OUT-1 in 2014. The estimated mean river water surface elevation at JB-OUT-1 was 4,667.4 ft. At the time of the survey, JB-OUT-1 was narrow (approximately $3 \mathrm{ft}$ [1 m] wide). The control gate at the wetland edge was connected to the breach by a narrow channel that passed through dense willow and other wetland vegetation, but did not contain obvious obstructions to flow. Based on our 2014 survey, the connection flow for JB-OUT-1 was 13,600 cfs (Table 3), and the highest channel cross-section was just past the breach (Figure B-16). The 2014 connection flow was 2,500 cfs lower than in 2012 and $600 \mathrm{cfs}$ higher than in 2005.

Estimated minimum fish passage flow for JB-OUT-1 in 2014 was 16,000 cfs, which was 2,700 cfs lower than in 2012 (Table 5).

JB-OUT-2. A total of 190 locations were surveyed at JB-OUT-2 in 2014. The estimated mean river water surface elevation at JB-OUT-2 was 4,668.0 ft. At the time of the survey, this broad low sandy breach led to a wide complex connection channel and the wetland. A sand road crossed the length of the breach. Based on our 2014 survey, the connection flow for JB-OUT-2 was 14,100 cfs (Table 3), and the highest channel cross-section was just past the breach (Figure B-17). The 2014 connection flow was 2,300 cfs lower than in 2012 and 1,100 cfs higher 

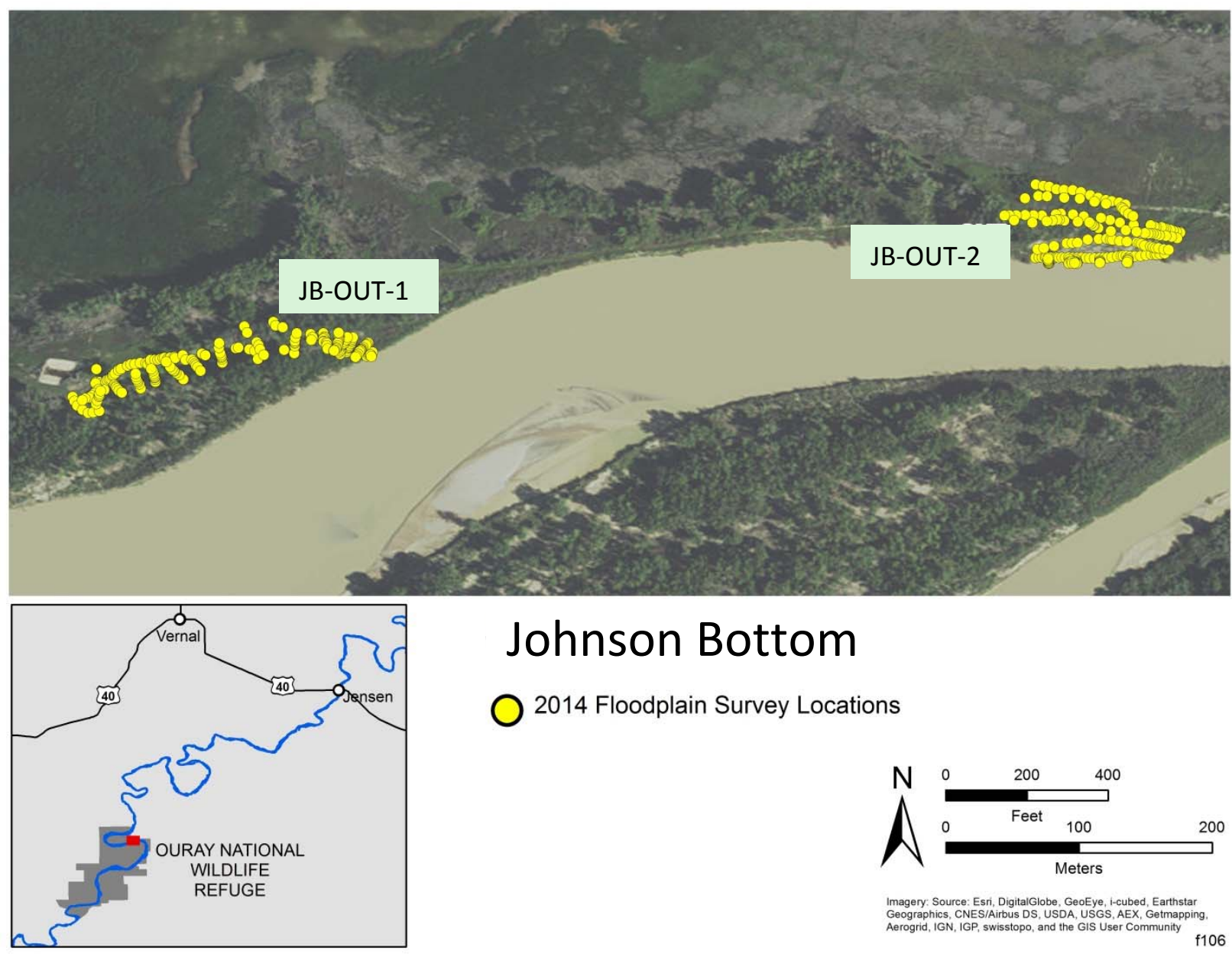

\section{Johnson Bottom}

2014 Floodplain Survey Locations

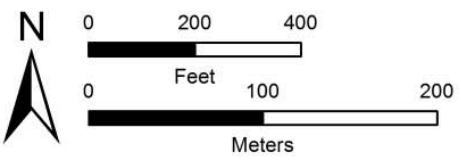

Imagery Source: Essi, DigitalGlobe, GeoEye, i-cubed, Earthstar
Geographics, CNES/Airitu DS USDA, USG, AEX Gertapping Geographics, CNES/Airbus DS, USDA, USGS, AEX, Getmapping,
Aerogrid, IGN, IGP, swistopo, and the GIS User Community
f106

FIGURE 7 Johnson Bottom Survey Locations in 2014. The date of the aerial imagery differs from the date of the survey; aerial imagery does not depict exact conditions at the time of the survey.

than in 2005. Estimated fish passage flow for JB-OUT-2 in 2014 was 16,500 cfs, which was 2,500 cfs lower than in 2012 (Table 5).

\subsection{LEOTA BOTTOM}

The Leota Bottom wetland was surveyed on October 30, 2014. The local flow at Leota Bottom at the time of the survey was calculated to be 2,200 cfs (Table 2).

Two downstream breach locations were surveyed at Leota Bottom: LB7-IN and LB7A-IN (Figure 8). Characterizations of levee breach and connection channel elevations at each of these locations are provided below. The 2014 estimated minimum connection flow at Leota Bottom was 12,700 cfs (LB7A-IN), which was about 700 cfs lower than in 2012 (Table 4); no estimates of connection are available from 2005. Minimum fish passage flow estimates for 

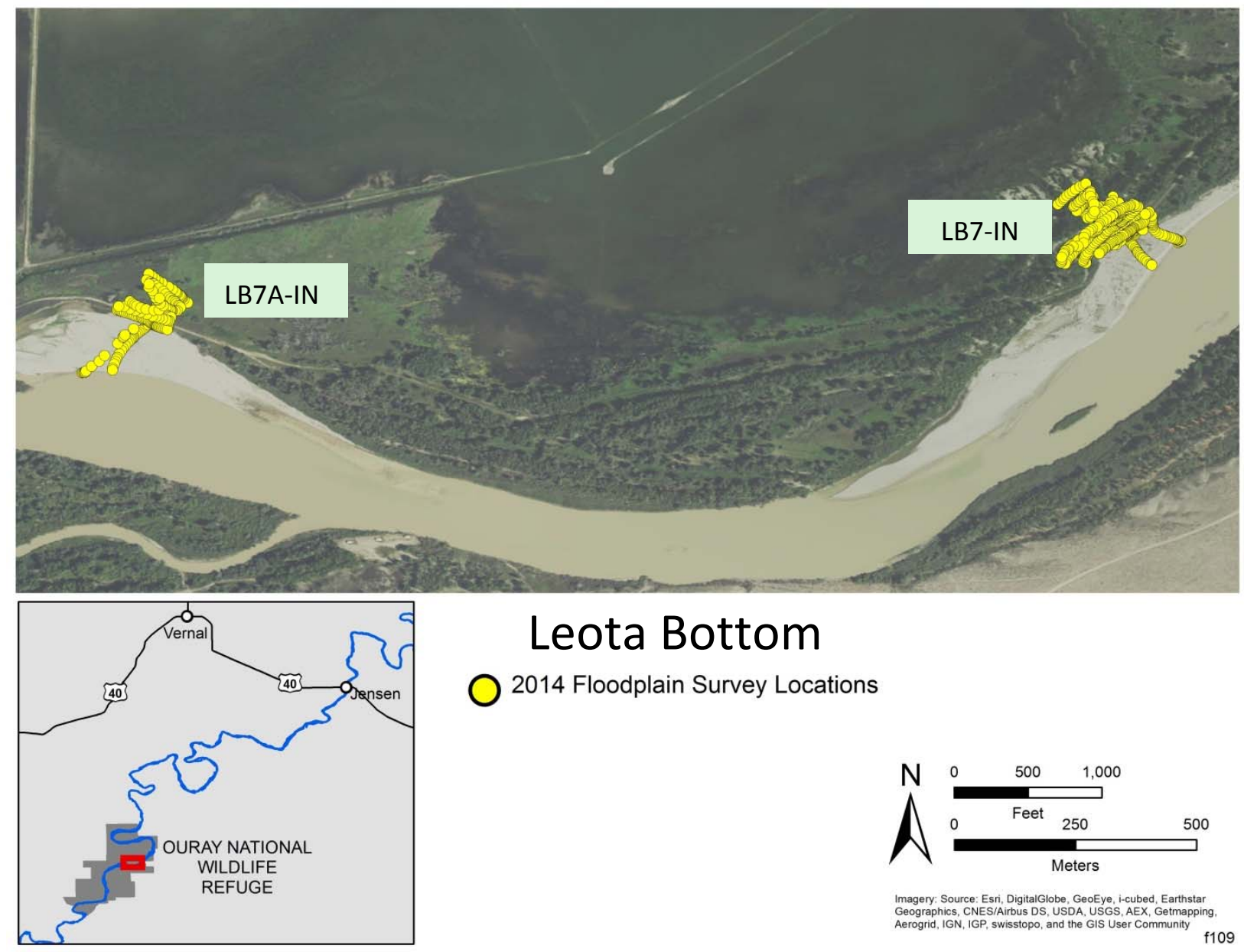

\section{Leota Bottom}

2014 Floodplain Survey Locations

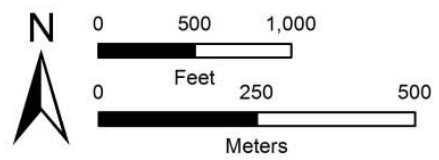

Imagery: Source: Esri, DigitalGlobe, GeoEye, i-cubed, Earthstar Geographics, CNES/Airbus DS, USDA, USGS, AEX, Getmapping,
Aerogrid, IGN, IGP, swisstopo, and the GIS User Community

FIGURE 8 Leota Bottom Survey Locations in 2014. The date of the aerial imagery differs from the date of the survey; aerial imagery does not depict exact conditions at the time of the survey.

Leota Bottom showed the same pattern as connection flow, but were on average 2,450 cfs higher (Table 5).

Leota Bottom was observed to be almost full on June 5, 2014 with two active breaches (flow at the Ouray gage was 17,400 cfs). On June 13, 2014, USFWS noted that the Leota Bottom floodplain wetland was connected and was at an elevation slightly higher than the river stage, as water was flowing out of the downstream breach into the river (T. Jones, USFWS, personal communication) at an Ouray gage flow of 14,700 cfs.

LB7-IN. A total of 593 locations were surveyed at LB7-IN in 2014. The estimated mean river water surface elevation at LB7-IN was 4,666.0 ft. At the time of the survey, LB7-IN was a broad breach of loose sand that led to a wide connection channel to the wetland; a sand road traversed the length of the breach. There was a large sandbar between the breach and the river edge. Based on our 2014 survey, the connection flow for LB7-IN was 14,500 cfs (Table 3), and 
the highest channel cross-section was one half of the distance between the breach and the wetland (Figure B-18). The 2014 estimated connection flow was 3,100 cfs lower than in 2012; no estimates were available for 2005. Estimated minimum fish passage flow for LB7-IN in 2014 was 17,000 cfs, which was 3,300 cfs lower than in 2012 (Table 5).

LB7A-IN. A total of 325 locations were surveyed at LB7A-IN in 2014. The estimated mean river water surface elevation at LB7A-IN was 4,664.5 ft. At the time of the survey, LB7AIN was a broad breach of mostly loose sand that led to a wide connection channel to the wetland; a road traversed the length of the breach, part of which was concrete. There was a large sandbar between the breach and the river edge. Based on our 2014 survey, the connection flow for LB7A-IN was 12,700 cfs (Table 3), and the highest channel cross-section was at the breach (Figure B-19). The 2014 minimum connection flow was 700 cfs lower than in 2012; no estimates were available for 2005. Estimated minimum fish passage flow for LB7A-IN in 2014 was 15,100 cfs, which was 700 cfs lower than in 2012 (Table 5).

\subsection{RESULTS SUMMARY}

Our 2014 survey identified differences in connection flow from our 2012 survey results (LaGory et al. 2016) and other reported values from previous surveys (Tetra Tech 2005; Bestgen et al. 2011; Table 3). Most of the 2014 connection flow estimates were lower than values we obtained in 2012 (mean difference -971 cfs), but still higher than reported values in 2005 (mean difference $+3,536 \mathrm{cfs}$ ). All but 4 of the 19 breaches and associated connection channels surveyed had lower estimated connection flows than in 2012.

The average estimated minimum floodplain connection flow (i.e., the lowest connection flow of any breach at a particular wetland) among the six floodplain wetlands surveyed in 2014 was 12,673 cfs (Table 4). This value is 1,508 cfs lower than the estimate in 2012, and essentially the same (+35 cfs) as in 2005. However, there was considerable variation among the wetlands in estimated minimum connection flow, ranging from 8,740 cfs at Escalante Ranch to 15,700 cfs at Stirrup. There was a comparable level of variation in 2012 (9,990 to 17,400 cfs), but much less variation in 2005 (11,166 to 13,000 cfs).

Changes in connection flows differed between upstream and downstream breaches with upstream breaches showing a smaller decrease since 2012 than downstream breaches (Table 4). The estimated mean minimum connection flow of upstream breaches in 2014 was 17,333 cfs $(14,600$ to 19,800 cfs) compared to 17,267 cfs $(15,300$ to 20,100 cfs) and 12,389 cfs (11,166 to 13,000 cfs) in 2012 and 2005, respectively. These values corresponded to an overall mean decrease for minimum connection flow of upstream breaches of $67 \mathrm{cfs}$ ( $-1,800$ to $+2,300 \mathrm{cfs}$ ) relative to 2012 and an increase of $4,945 \mathrm{cfs}(+1,600$ to $+6,800)$ relative to 2005 . The estimated mean minimum connection flow of downstream breaches in 2014 was 12,673 cfs $(8,740$ to $15,700 \mathrm{cfs})$ compared to $14,182 \mathrm{cfs}(9,990$ to $17,400 \mathrm{cfs})$ in 2012 , and $13,067 \mathrm{cfs}(12,433$ to $13,900 \mathrm{cfs})$ in 2005. These values corresponded to an overall mean decrease for minimum connection flow of downstream breaches of 1,508 cfs $(-2,560$ to $+410 \mathrm{cfs})$ relative to 2012 , and a 399 cfs decrease $(-3,693$ to $+2,700 \mathrm{cfs})$ relative to 2005 . 
Estimated fish passage flows in 2014 were approximately 2,400 cfs higher than connection flows in the Ouray National Wildlife Refuge wetlands (Johnson Bottom and Leota Bottom) and 3,150 to 3,375 cfs higher than connection flows in the wetlands further upstream. In 2014, the mean minimum fish passage flow for the floodplain wetlands surveyed was 19,400 cfs (11,600 to 27,900 cfs; Table 5). In 2014, the mean minimum fish passage flow for the floodplain wetlands surveyed (i.e., the lowest of all levee breaches in each wetland) was approximately 15,500 cfs $(11,500$ to 19,000 cfs $)$.

\section{DISCUSSION}

We reassessed floodplain wetland connection of six priority wetlands in the Middle Green River in 2014 to estimate connection flows following the moderately high peak flow (20,100 cfs) of 2014 and determine if this high flow resulted in changes in the levee breaches and connection channels of these wetlands. Knowing the actual connection flows in any given year is critical to defining the target peak flows during the runoff season to meet the biological objectives identified in Muth et al. (2000) and in the Larval Trigger Study Plan (Larval Trigger Study Plan Ad Hoc Committee 2012).

Our 2014 survey identified changes since our 2012 survey (LaGory et al. 2016), and documented an overall decrease (mean 971 cfs) in connection flows since 2012. There was variability in the amount of change among breaches; the greatest increase in connection flow was 2,600 cfs (ER-IN-5) while the greatest decrease was 3,900 cfs (AB-IN-3). Only 3 breaches experienced an increase in connection flow (ER-IN-5, ER-IN-7, and AB-OUT) after the 2014 peak flow, and one (ER-IN-3) showed no change; the other 15 breaches experienced a decrease. Despite these overall reductions, the 2014 peak flow did not completely reverse the increases in connection flows caused by the high magnitude peak flows of 2008 and 2011.

In the wetlands studied, upstream breaches were topographically higher than the wetland, while downstream breaches were lower than the wetland (LaGory et al. 2016). This topographic variation likely explains differences among breaches in the magnitude of changes in connection flows since 2012. Upstream breaches and their connection channels, which tend to be depositional areas, showed less decrease in connection levels than downstream breaches, which tend to scour as the wetlands drain during flood recession.

Although suspended sediment concentration data are not currently available for the study area, it is expected that concentrations would have been lower during the lower magnitude 2014 flow compared to the higher magnitude 2011 peak flow. A lower sediment load would have made the 2014 flow more erosive and could have resulted in net erosion of 2011 sand deposits. Water entering breaches could have eroded old deposits while depositing less new sand. It is not known if a series of moderately high peak flows (18,600 to 21,000 cfs) would further reduce flows needed to connect floodplain wetlands to the main channel. Study of even lower peak flows that only connect downstream wetland breaches (e.g. 11,000 to 15,000 cfs) could also yield interesting results that would increase our understanding of the effects of peak flow 
magnitude on floodplain wetland connection. The 2014 results confirm the need for periodic reassessments of levee breaches and connection channels following peak flows.

\section{CONCLUSIONS}

- Changes from 2012 and 2005 in estimated connection flows at levee breaches of six priority floodplain wetlands in the middle Green River were observed in 2014, and these changes resulted mostly from erosion of sediment in breaches and connection channels during intervening high peak flows.

- Mean minimum connection flow for surveyed wetlands in 2014 was 12,673 cfs compared to 14,182 cfs in 2012, a decrease of 1,508 cfs.

- Most individual breaches showed a decrease in connection flow compared to 2012; the mean change was a decrease of 971 cfs. Only three breaches showed an increase in connection flow. This general reduction in connection flow after the 2014 peak flow suggests that moderately high peak flows (18,600 to 21,000 cfs) can reverse the buildup of sediment in levee breaches and connection channels caused by deposition at very high peak flows (>30,000 cfs).

- Both upstream and downstream breaches showed decreases in connection flow, but the mean decrease for upstream breaches (67 cfs) was less than that for downstream breaches (1,508 cfs). In 2014, mean minimum connection flow of upstream breaches was 17,333 cfs compared to 17,267 cfs in 2012. In 2014, mean minimum connection flow of downstream breaches was 12,673 cfs compared to 14,182 cfs in 2012.

- Estimated fish passage flows (those flows needed to allow passage of subadult and adult razorback suckers) were approximately 2,400 cfs higher than connection flows in the Ouray National Wildlife Refuge wetlands (Johnson Bottom and Leota Bottom) and 3,150 to 3,375 cfs higher for the wetlands further upstream. The mean estimated fish passage flow for the floodplain wetlands surveyed in 2014 was approximately 19,400 cfs $(11,500$ to $25,700 \mathrm{cfs}$ ). The mean estimated minimum fish passage flow for the floodplain wetlands surveyed (i.e., the lowest of all levee breaches in each wetland) was approximately 15,500 cfs (11,500 to 19,000 cfs). 


\section{RECOMMENDATIONS}

- Resurvey floodplain wetland breaches and their connection channels following peak flows that exceed previously determined connection flows to determine if those peak flows have altered connection flows.

- Surveys should be conducted to determine if the apparent reduction in connection flows that resulted from the moderately high 2014 peak would continue with subsequent moderate peak flows.

- Determine connection of floodplain wetlands annually by direct observation. Ideally, determinations would be made annually of initial connection flows at upstream and downstream breaches and the degree of filling and draining through the peak flow cycle.

- Measure the surface area of floodplain wetlands after peak flows recede and through the summer and winter to determine if floodplain wetlands provide suitable habitat for razorback suckers between flooding events that reconnect the wetlands to the main channel.

- Consider modification of floodplain wetland breaches and connection channels to provide connection to the main channel river at a return frequency of 1.5 years (probability of about $67 \%$ ) to mimic pre-dam flooding frequency.

- Consider modifications of wetlands to prevent sediment deposition from blocking inflow. These modifications could include (1) actively reconfiguring levee breaches, connection channels, and wetland topography to minimize the blockage of connection channels; (2) filling or allowing the filling of upstream breaches; (3) creating control structures such as those that have been successfully deployed at Stewart Lake, Johnson Bottom, and Old Charley Wash; and (4) managing vegetation encroachment that exacerbates sediment deposition in breaches and channels.

\section{REFERENCES}

Bestgen, K.R., G.B. Haines, and A.A. Hill, 2011, Synthesis of Flood Plain Wetland Information: Timing of Razorback Sucker Reproduction in the Green River, Utah, Related to Stream Flow, Water Temperature, and Flood Plain Wetland Availability, final report to the Upper Colorado River Endangered Fish Recovery Program, Denver, Colorado, Larval Fish Laboratory Contribution 163. 
Burdick, B.D., 1997, Minimum Flow Recommendation for Passage of Colorado Squawfish and Razorback Sucker in the 2.3-mile Reach of the Lower Gunnison River: Redlands Diversion Dam to the Colorado River Confluence, final report to the Upper Colorado River Endangered Fish Recovery Program, Denver, Colorado.

Flo Engineering, 1997, Green River Floodplain Habitat Restoration Investigations, Bureau of Land Management Sites and Ouray National Wildlife Refuge Sites Near Vernal, Utah, Final Report. Prepared for the Recovery Program for the Endangered Fishes of the Upper Colorado River. Breckenridge, CO.

Heitmeyer, M.E. and L.H. Fredrickson, 2005, An Evaluation of Ecosystem Restoration and Management Options for the Ouray National Wildlife Refuge, Utah, report prepared for the U.S. Fish and Wildlife Service, Region 6, Denver, Colorado.

LaGory, K.E., J.W. Hayse, and D. Tomasko, 2003, Recommended Priorities for Geomorphology Research in Endangered Fish Habitats of the Upper Colorado River Basin, final report to the U.S. Fish and Wildlife Service Colorado River Endangered Fish Recovery Program, Denver, Colorado.

LaGory, K.E., L.J. Walston, and C.C. Weber, 2016, 2012 Reassessment of Floodplain Wetland Connections in the Middle Green River, Utah, Environmental Science Division, Argonne National Laboratory, ANL/EVS-15/1, draft report to the U.S. Fish and Wildlife Service Colorado River Endangered Fish Recovery Program, Denver, Colorado.

Larval Trigger Study Plan Ad Hoc Committee, 2012, Study Plan to Examine the Effects of Using Larval Razorback Sucker Occurrence in the Green River as a Trigger for Flaming Gorge Dam Peak Releases, final report prepared for the Upper Colorado River Endangered Fish Recovery Program, Denver, March.

Muth, R.T., L.W. Crist, K.E. LaGory, J.W. Hayse, K.R. Bestgen, T.P. Ryan, J.K. Lyons, and R.A. Valdez, 2000, Flow and Temperature Recommendations for Endangered Fishes in the Green River Downstream of Flaming Gorge Dam, final report to the Upper Colorado River Endangered Fish Recovery Program, Denver, Project No. FG-53.

Tetra Tech, 2005, Floodplain Habitat Restoration, 2005 Monitoring Final Report, Green River, Utah, prepared for the Upper Colorado River Endangered Fish Recovery Program, Denver, Colorado, GSA Contract Tetra Tech Inc., Project No. 0929-004-00.

Valdez, R.A., and P. Nelson, 2004, Green River Subbasin Floodplain Management Plan, Upper Colorado River Endangered Fish Recovery Program, Project Number C-6, Denver, Colorado. 


\section{APPENDIX A:}

\section{USGS STAGE-FLOW TABLES FOR THE JENSEN AND OURAY GAGES}


This page intentionally left blank. 


\section{APPENDIX A:}

\section{USGS STAGE-FLOW TABLE FOR THE JENSEN AND OURAY GAGES}

This appendix presents the stage-flow tables for the Jensen gage (USGS 09261000) and Ouray gage (USGS 9272400) developed by the U.S. Geological Survey (USGS) (Tables A-1 and A-2, respectively). These tables were used as the basis for determining the flows that would connect wetlands and allow passage of fish at surveyed levee breaches and connection channels. 
This page intentionally left blank. 
TABLE A-1 USGS Stage-Flow Table for the Jensen Gage (USGS 09261000) in 2005, 2012, and 2014

\begin{tabular}{rrrr}
\hline & & & \\
\cline { 2 - 4 } Stage (ft) & 2005 & 2012 & 2014 \\
\hline 1.87 & 795 & 1,080 & 1,150 \\
1.88 & 803 & 1,090 & 1,160 \\
1.89 & 811 & 1,100 & 1,160 \\
1.90 & 818 & 1,110 & 1,170 \\
1.91 & 826 & 1,120 & 1,180 \\
1.92 & 834 & 1,130 & 1,190 \\
1.93 & 842 & 1,140 & 1,200 \\
1.94 & 850 & 1,150 & 1,210 \\
1.95 & 858 & 1,160 & 1,220 \\
1.96 & 865 & 1,170 & 1,230 \\
1.97 & 873 & 1,180 & 1,240 \\
1.98 & 881 & 1,190 & 1,250 \\
1.99 & 889 & 1,200 & 1,260 \\
2.00 & 898 & 1,210 & 1,270 \\
2.01 & 906 & 1,220 & 1,270 \\
2.02 & 914 & 1,230 & 1,280 \\
2.03 & 922 & 1,240 & 1,290 \\
2.04 & 930 & 1,260 & 1,300 \\
2.05 & 939 & 1,270 & 1,310 \\
2.06 & 947 & 1,280 & 1,320 \\
2.07 & 955 & 1,290 & 1,330 \\
2.08 & 964 & 1,300 & 1,340 \\
2.09 & 972 & 1,310 & 1,350 \\
2.10 & 981 & 1,320 & 1,360 \\
2.11 & 989 & 1,330 & 1,370 \\
2.12 & 998 & 1,340 & 1,380 \\
2.13 & 1,010 & 1,360 & 1,390 \\
2.14 & 1,020 & 1,370 & 1,400 \\
2.15 & 1,020 & 1,380 & 1,410 \\
2.16 & 1,030 & 1,390 & 1,420 \\
2.17 & 1,040 & 1,400 & 1,430 \\
2.18 & 1,050 & 1,410 & 1,440 \\
2.19 & 1,060 & 1,420 & 1,450 \\
2.20 & 1,070 & 1,440 & 1,460 \\
2.21 & 1,080 & 1,450 & 1,470 \\
2.22 & 1,090 & 1,460 & 1,480 \\
2.23 & 1,100 & 1,470 & 1,490 \\
2.24 & 1,100 & 1,480 & 1,500
\end{tabular}

\begin{tabular}{rrrr}
\hline & & & \\
& & & \\
\cline { 2 - 4 } Stage (ft) & 2005 & 2012 & 2014 \\
\hline 2.25 & 1,110 & 1,500 & 1,510 \\
2.26 & 1,120 & 1,510 & 1,520 \\
2.27 & 1,130 & 1,520 & 1,530 \\
2.28 & 1,140 & 1,530 & 1,540 \\
2.29 & 1,150 & 1,540 & 1,560 \\
2.30 & 1,160 & 1,560 & 1,570 \\
2.31 & 1,170 & 1,570 & 1,580 \\
2.32 & 1,180 & 1,580 & 1,590 \\
2.33 & 1,190 & 1,590 & 1,600 \\
2.34 & 1,200 & 1,600 & 1,610 \\
2.35 & 1,210 & 1,620 & 1,620 \\
2.36 & 1,220 & 1,630 & 1,630 \\
2.37 & 1,230 & 1,640 & 1,640 \\
2.38 & 1,240 & 1,650 & 1,650 \\
2.39 & 1,250 & 1,670 & 1,660 \\
2.40 & 1,260 & 1,680 & 1,670 \\
2.41 & 1,270 & 1,690 & 1,690 \\
2.42 & 1,280 & 1,700 & 1,700 \\
2.43 & 1,290 & 1,720 & 1,710 \\
2.44 & 1,290 & 1,730 & 1,720 \\
2.45 & 1,300 & 1,740 & 1,730 \\
2.46 & 1,310 & 1,750 & 1,740 \\
2.47 & 1,330 & 1,770 & 1,750 \\
2.48 & 1,340 & 1,780 & 1,760 \\
2.49 & 1,350 & 1,790 & 1,780 \\
2.62 & 1,480 & 1,970 & 1,930 \\
2.63 & 1,490 & 1,980 & 1,940
\end{tabular}




\begin{tabular}{rrrr}
\hline & & & \\
\cline { 2 - 4 } Stage (ft) & 2005 & 2012 & 2014 \\
\hline 2.64 & 1,500 & 1,990 & 1,950 \\
2.65 & 1,510 & 2,010 & 1,960 \\
2.66 & 1,520 & 2,020 & 1,980 \\
2.67 & 1,540 & 2,030 & 1,990 \\
2.68 & 1,550 & 2,050 & 2,000 \\
2.69 & 1,560 & 2,060 & 2,010 \\
2.70 & 1,570 & 2,080 & 2,030 \\
2.71 & 1,580 & 2,090 & 2,040 \\
2.72 & 1,590 & 2,100 & 2,050 \\
2.73 & 1,600 & 2,120 & 2,060 \\
2.74 & 1,610 & 2,130 & 2,080 \\
2.75 & 1,620 & 2,150 & 2,090 \\
2.76 & 1,640 & 2,160 & 2,100 \\
2.77 & 1,650 & 2,170 & 2,110 \\
2.78 & 1,660 & 2,190 & 2,130 \\
2.79 & 1,670 & 2,200 & 2,140 \\
2.80 & 1,680 & 2,220 & 2,150 \\
2.81 & 1,690 & 2,230 & 2,170 \\
2.82 & 1,700 & 2,240 & 2,180 \\
2.83 & 1,720 & 2,260 & 2,190 \\
2.84 & 1,730 & 2,270 & 2,200 \\
2.85 & 1,740 & 2,290 & 2,220 \\
2.86 & 1,750 & 2,300 & 2,230 \\
2.87 & 1,760 & 2,320 & 2,240 \\
2.88 & 1,780 & 2,330 & 2,260 \\
2.89 & 1,790 & 2,350 & 2,270 \\
2.90 & 1,800 & 2,360 & 2,280 \\
2.91 & 1,810 & 2,380 & 2,300 \\
2.92 & 1,820 & 2,390 & 2,310 \\
2.93 & 1,840 & 2,410 & 2,320 \\
2.94 & 1,850 & 2,420 & 2,340 \\
2.95 & 1,860 & 2,440 & 2,350 \\
2.96 & 1,870 & 2,450 & 2,360 \\
2.97 & 1,880 & 2,470 & 2,380 \\
2.98 & 1,900 & 2,480 & 2,390 \\
2.99 & 1,910 & 2,500 & 2,400 \\
3.00 & 1,920 & 2,510 & 2,420 \\
& 1,930 & 2,530 & 2,430 \\
3.960 & 2,540 & 2,450 \\
& & 2,560 & 2,460 \\
& & 2,570 & 2,470
\end{tabular}

\begin{tabular}{|c|c|c|c|}
\hline \multirow[b]{2}{*}{ Stage $(\mathrm{ft})$} & \multicolumn{3}{|c|}{ Flow (cfs) } \\
\hline & 2005 & 2012 & 2014 \\
\hline 3.05 & 1,980 & 2,590 & 2,490 \\
\hline 3.06 & 2,000 & 2,600 & 2,500 \\
\hline 3.07 & 2,010 & 2,620 & 2,520 \\
\hline 3.08 & 2,020 & 2,630 & 2,530 \\
\hline 3.09 & 2,030 & 2,650 & 2,540 \\
\hline 3.10 & 2,050 & 2,670 & 2,560 \\
\hline 3.11 & 2,060 & 2,680 & 2,570 \\
\hline 3.12 & 2,070 & 2,700 & 2,590 \\
\hline 3.13 & 2,090 & 2,710 & 2,600 \\
\hline 3.14 & 2,100 & 2,730 & 2,620 \\
\hline 3.15 & 2,110 & 2,740 & 2,630 \\
\hline 3.16 & 2,130 & 2,760 & 2,640 \\
\hline 3.17 & 2,140 & 2,780 & 2,660 \\
\hline 3.18 & 2,150 & 2,790 & 2,670 \\
\hline 3.19 & 2,160 & 2,810 & 2,690 \\
\hline 3.20 & 2,180 & 2,820 & 2,700 \\
\hline 3.21 & 2,190 & 2,840 & 2,720 \\
\hline 3.22 & 2,200 & 2,860 & 2,730 \\
\hline 3.23 & 2,220 & 2,870 & 2,750 \\
\hline 3.24 & 2,230 & 2,890 & 2,760 \\
\hline 3.25 & 2,250 & 2,900 & 2,780 \\
\hline 3.26 & 2,260 & 2,920 & 2,790 \\
\hline 3.27 & 2,270 & 2,940 & 2,810 \\
\hline 3.28 & 2,290 & 2,950 & 2,820 \\
\hline 3.29 & 2,300 & 2,970 & 2,840 \\
\hline 3.30 & 2,310 & 2,990 & 2,850 \\
\hline 3.31 & 2,330 & 3,000 & 2,870 \\
\hline 3.32 & 2,340 & 3,020 & 2,880 \\
\hline 3.33 & 2,350 & 3,040 & 2,900 \\
\hline 3.34 & 2,370 & 3,050 & 2,910 \\
\hline 3.35 & 2,380 & 3,070 & 2,930 \\
\hline 3.36 & 2,400 & 3,090 & 2,940 \\
\hline 3.37 & 2,410 & 3,100 & 2,960 \\
\hline 3.38 & 2,420 & 3,120 & 2,970 \\
\hline 3.39 & 2,440 & 3,140 & 2,990 \\
\hline 3.40 & 2,450 & 3,150 & 3,010 \\
\hline 3.41 & 2,470 & 3,170 & 3,020 \\
\hline 3.42 & 2,480 & 3,190 & 3,040 \\
\hline 3.43 & 2,500 & 3,200 & 3,050 \\
\hline 3.44 & 2,510 & 3,220 & 3,070 \\
\hline 3.45 & 2,520 & 3,240 & 3,080 \\
\hline
\end{tabular}




\begin{tabular}{cccc}
\hline & & & \\
\cline { 2 - 4 } Stage (ft) & 2005 & 2012 & 2014 \\
\hline 3.46 & 2,540 & 3,260 & 3,100 \\
3.47 & 2,550 & 3,270 & 3,120 \\
3.48 & 2,570 & 3,290 & 3,130 \\
3.49 & 2,580 & 3,310 & 3,150 \\
3.50 & 2,600 & 3,320 & 3,160 \\
3.51 & 2,610 & 3,340 & 3,180 \\
3.52 & 2,630 & 3,360 & 3,200 \\
3.53 & 2,640 & 3,380 & 3,210 \\
3.54 & 2,660 & 3,390 & 3,230 \\
3.55 & 2,670 & 3,410 & 3,250 \\
3.56 & 2,690 & 3,430 & 3,260 \\
3.57 & 2,700 & 3,450 & 3,280 \\
3.58 & 2,720 & 3,460 & 3,300 \\
3.59 & 2,730 & 3,480 & 3,310 \\
3.60 & 2,750 & 3,500 & 3,330 \\
3.61 & 2,760 & 3,520 & 3,340 \\
3.62 & 2,780 & 3,520 & 3,360 \\
3.63 & 2,790 & 3,540 & 3,380 \\
3.64 & 2,810 & 3,550 & 3,400 \\
3.65 & 2,820 & 3,570 & 3,410 \\
3.66 & 2,840 & 3,590 & 3,430 \\
3.67 & 2,850 & 3,610 & 3,450 \\
3.68 & 2,870 & 3,630 & 3,460 \\
3.69 & 2,890 & 3,640 & 3,480 \\
3.70 & 2,900 & 3,660 & 3,500 \\
3.71 & 2,920 & 3,680 & 3,510 \\
3.72 & 2,930 & 3,700 & 3,530 \\
3.73 & 2,950 & 3,720 & 3,550 \\
3.74 & 2,960 & 3,730 & 3,570 \\
3.75 & 2,980 & 3,750 & 3,580 \\
3.76 & 3,000 & 3,770 & 3,600 \\
3.77 & 3,010 & 3,790 & 3,620 \\
3.78 & 3,030 & 3,810 & 3,630 \\
3.79 & 3,040 & 3,830 & 3,650 \\
3.80 & 3,060 & 3,850 & 3,670 \\
3.81 & 3,080 & 3,860 & 3,690 \\
3,83 & 3,090 & 3,880 & 3,710 \\
3,110 & 3,900 & 3,730 \\
3,120 & 3,920 & 3,760 \\
3,160 & 3,940 & 3,800
\end{tabular}

\begin{tabular}{|c|c|c|c|}
\hline \multirow[b]{2}{*}{ Stage $(\mathrm{ft})$} & \multicolumn{3}{|c|}{ Flow (cfs) } \\
\hline & 2005 & 2012 & 2014 \\
\hline 3.87 & 3,170 & 3,960 & 3,820 \\
\hline 3.88 & 3,190 & 3,980 & 3,840 \\
\hline 3.89 & 3,210 & 4,000 & 3,860 \\
\hline 3.90 & 3,220 & 4,010 & 3,890 \\
\hline 3.91 & 3,240 & 4,030 & 3,910 \\
\hline 3.92 & 3,260 & 4,050 & 3,930 \\
\hline 3.93 & 3,270 & 4,070 & 3,950 \\
\hline 3.94 & 3,290 & 4,090 & 3,970 \\
\hline 3.95 & 3,310 & 4,110 & 4,000 \\
\hline 3.96 & 3,320 & 4,130 & 4,020 \\
\hline 3.97 & 3,340 & 4,150 & 4,040 \\
\hline 3.98 & 3,360 & 4,170 & 4,060 \\
\hline 3.99 & 3,370 & 4,190 & 4,080 \\
\hline 4.00 & 3,390 & 4,210 & 4,110 \\
\hline 4.01 & 3,410 & 4,230 & 4,130 \\
\hline 4.02 & 3,420 & 4,240 & 4,150 \\
\hline 4.03 & 3,440 & 4,260 & 4,170 \\
\hline 4.04 & 3,460 & 4,280 & 4,200 \\
\hline 4.05 & 3,480 & 4,300 & 4,220 \\
\hline 4.06 & 3,490 & 4,320 & 4,240 \\
\hline 4.07 & 3,510 & 4,340 & 4,260 \\
\hline 4.08 & 3,530 & 4,340 & 4,280 \\
\hline 4.09 & 3,550 & 4,360 & 4,310 \\
\hline 4.10 & 3,560 & 4,380 & 4,330 \\
\hline 4.11 & 3,580 & 4,400 & 4,350 \\
\hline 4.12 & 3,600 & 4,420 & 4,370 \\
\hline 4.13 & 3,620 & 4,440 & 4,400 \\
\hline 4.14 & 3,630 & 4,460 & 4,420 \\
\hline 4.15 & 3,650 & 4,480 & 4,440 \\
\hline 4.16 & 3,670 & 4,500 & 4,460 \\
\hline 4.17 & 3,690 & 4,520 & 4,490 \\
\hline 4.18 & 3,700 & 4,540 & 4,510 \\
\hline 4.19 & 3,720 & 4,560 & 4,530 \\
\hline 4.20 & 3,740 & 4,580 & 4,550 \\
\hline 4.21 & 3,760 & 4,600 & 4,580 \\
\hline 4.22 & 3,780 & 4,620 & 4,600 \\
\hline 4.23 & 3,790 & 4,640 & 4,620 \\
\hline 4.24 & 3,810 & 4,660 & 4,650 \\
\hline 4.25 & 3,830 & 4,680 & 4,670 \\
\hline 4.26 & 3,850 & 4,700 & 4,690 \\
\hline 4.27 & 3,870 & 4,720 & 4,710 \\
\hline
\end{tabular}




\begin{tabular}{|c|c|c|c|}
\hline \multirow[b]{2}{*}{ Stage (ft) } & \multicolumn{3}{|c|}{ Flow (cfs) } \\
\hline & 2005 & 2012 & 2014 \\
\hline 4.28 & 3,890 & 4,740 & 4,740 \\
\hline 4.29 & 3,900 & 4,760 & 4,760 \\
\hline 4.30 & 3,920 & 4,790 & 4,780 \\
\hline 4.31 & 3,940 & 4,790 & 4,810 \\
\hline 4.32 & 3,960 & 4,810 & 4,830 \\
\hline 4.33 & 3,980 & 4,830 & 4,850 \\
\hline 4.34 & 4,000 & 4,850 & 4,880 \\
\hline 4.35 & 4,020 & 4,870 & 4,900 \\
\hline 4.36 & 4,030 & 4,890 & 4,920 \\
\hline 4.37 & 4,050 & 4,910 & 4,950 \\
\hline 4.38 & 4,070 & 4,930 & 4,970 \\
\hline 4.39 & 4,090 & 4,950 & 4,990 \\
\hline 4.40 & 4,110 & 4,970 & 5,020 \\
\hline 4.41 & 4,130 & 4,990 & 5,040 \\
\hline 4.42 & 4,150 & 5,010 & 5,060 \\
\hline 4.43 & 4,170 & 5,040 & 5,090 \\
\hline 4.44 & 4,190 & 5,060 & 5,110 \\
\hline 4.45 & 4,210 & 5,080 & 5,130 \\
\hline 4.46 & 4,230 & 5,100 & 5,160 \\
\hline 4.47 & 4,240 & 5,120 & 5,180 \\
\hline 4.48 & 4,260 & 5,140 & 5,200 \\
\hline 4.49 & 4,280 & 5,160 & 5,230 \\
\hline 4.50 & 4,300 & 5,180 & 5,250 \\
\hline 4.51 & 4,320 & 5,210 & 5,270 \\
\hline 4.52 & 4,340 & 5,230 & 5,300 \\
\hline 4.53 & 4,360 & 5,250 & 5,320 \\
\hline 4.54 & 4,380 & 5,250 & 5,340 \\
\hline 4.55 & 4,400 & 5,270 & 5,370 \\
\hline 4.56 & 4,420 & 5,290 & 5,390 \\
\hline 4.57 & 4,440 & 5,310 & 5,420 \\
\hline 4.58 & 4,460 & 5,330 & 5,440 \\
\hline 4.59 & 4,480 & 5,360 & 5,460 \\
\hline 4.60 & 4,500 & 5,380 & 5,490 \\
\hline 4.61 & 4,520 & 5,400 & 5,510 \\
\hline 4.62 & 4,540 & 5,420 & 5,530 \\
\hline 4.63 & 4,560 & 5,440 & 5,560 \\
\hline 4.64 & 4,580 & 5,470 & 5,580 \\
\hline 4.65 & 4,600 & 5,490 & 5,610 \\
\hline 4.66 & 4,620 & 5,510 & 5,630 \\
\hline 4.67 & 4,640 & 5,530 & 5,650 \\
\hline 4.68 & 4,660 & 5,550 & 5,680 \\
\hline
\end{tabular}

\begin{tabular}{|c|c|c|c|}
\hline \multirow[b]{2}{*}{ Stage $(\mathrm{ft})$} & \multicolumn{3}{|c|}{ Flow (cfs) } \\
\hline & 2005 & 2012 & 2014 \\
\hline 4.69 & 4,680 & 5,580 & 5,700 \\
\hline 4.70 & 4,700 & 5,600 & 5,730 \\
\hline 4.71 & 4,720 & 5,620 & 5,750 \\
\hline 4.72 & 4,740 & 5,640 & 5,770 \\
\hline 4.73 & 4,760 & 5,660 & 5,800 \\
\hline 4.74 & 4,780 & 5,690 & 5,820 \\
\hline 4.75 & 4,810 & 5,710 & 5,850 \\
\hline 4.76 & 4,830 & 5,730 & 5,870 \\
\hline 4.77 & 4,850 & 5,730 & 5,900 \\
\hline 4.78 & 4,870 & 5,750 & 5,920 \\
\hline 4.79 & 4,890 & 5,780 & 5,940 \\
\hline 4.80 & 4,920 & 5,800 & 5,970 \\
\hline 4.81 & 4,940 & 5,820 & 5,990 \\
\hline 4.82 & 4,960 & 5,840 & 6,020 \\
\hline 4.83 & 4,980 & 5,870 & 6,040 \\
\hline 4.84 & 5,000 & 5,890 & 6,070 \\
\hline 4.85 & 5,030 & 5,910 & 6,090 \\
\hline 4.86 & 5,050 & 5,940 & 6,120 \\
\hline 4.87 & 5,070 & 5,960 & 6,140 \\
\hline 4.88 & 5,090 & 5,980 & 6,160 \\
\hline 4.89 & 5,120 & 6,000 & 6,190 \\
\hline 4.90 & 5,140 & 6,030 & 6,210 \\
\hline 4.91 & 5,160 & 6,050 & 6,240 \\
\hline 4.92 & 5,180 & 6,070 & 6,260 \\
\hline 4.93 & 5,210 & 6,100 & 6,290 \\
\hline 4.94 & 5,230 & 6,120 & 6,310 \\
\hline 4.95 & 5,250 & 6,140 & 6,340 \\
\hline 4.96 & 5,280 & 6,170 & 6,360 \\
\hline 4.97 & 5,300 & 6,190 & 6,390 \\
\hline 4.98 & 5,320 & 6,210 & 6,410 \\
\hline 4.99 & 5,340 & 6,230 & 6,440 \\
\hline 5.00 & 5,370 & 6,230 & 6,460 \\
\hline 5.01 & 5,390 & 6,260 & 6,490 \\
\hline 5.02 & 5,410 & 6,280 & 6,510 \\
\hline 5.03 & 5,440 & 6,300 & 6,540 \\
\hline 5.04 & 5,460 & 6,330 & 6,560 \\
\hline 5.05 & 5,480 & 6,350 & 6,590 \\
\hline 5.06 & 5,510 & 6,380 & 6,610 \\
\hline 5.07 & 5,530 & 6,400 & 6,640 \\
\hline 5.08 & 5,550 & 6,420 & 6,660 \\
\hline 5.09 & 5,580 & 6,450 & 6,690 \\
\hline
\end{tabular}




\begin{tabular}{rrrr} 
& & & \\
& & Flow (cfs) & \\
\cline { 2 - 4 } Stage (ft) & 2005 & 2012 & 2014 \\
\hline 5.10 & 5,600 & 6,470 & 6,710 \\
5.11 & 5,620 & 6,490 & 6,740 \\
5.12 & 5,650 & 6,520 & 6,760 \\
5.13 & 5,670 & 6,540 & 6,790 \\
5.14 & 5,700 & 6,570 & 6,810 \\
5.15 & 5,720 & 6,590 & 6,840 \\
5.16 & 5,740 & 6,610 & 6,860 \\
5.17 & 5,770 & 6,640 & 6,890 \\
5.18 & 5,790 & 6,660 & 6,910 \\
5.19 & 5,820 & 6,690 & 6,940 \\
5.20 & 5,840 & 6,710 & 6,960 \\
5.21 & 5,860 & 6,730 & 6,990 \\
5.22 & 5,890 & 6,760 & 7,010 \\
5.23 & 5,910 & 6,780 & 7,040 \\
5.24 & 5,940 & 6,780 & 7,060 \\
5.25 & 5,960 & 6,810 & 7,090 \\
5.26 & 5,990 & 6,830 & 7,120 \\
5.27 & 6,010 & 6,860 & 7,140 \\
5.28 & 6,030 & 6,880 & 7,170 \\
5.29 & 6,060 & 6,900 & 7,190 \\
5.30 & 6,080 & 6,930 & 7,220 \\
5.31 & 6,110 & 6,950 & 7,240 \\
5.32 & 6,130 & 6,980 & 7,270 \\
5.33 & 6,160 & 7,000 & 7,290 \\
5.34 & 6,180 & 7,030 & 7,320 \\
5.35 & 6,210 & 7,050 & 7,350 \\
5.36 & 6,230 & 7,080 & 7,370 \\
5.37 & 6,260 & 7,100 & 7,400 \\
5.38 & 6,280 & 7,130 & 7,420 \\
5.39 & 6,310 & 7,150 & 7,450 \\
5.40 & 6,330 & 7,180 & 7,470 \\
5.41 & 6,360 & 7,200 & 7,500 \\
5.42 & 6,380 & 7,230 & 7,530 \\
5.43 & 6,410 & 7,250 & 7,550 \\
5.44 & 6,430 & 7,280 & 7,580 \\
5.45 & 6,460 & 7,300 & 7,600 \\
5.46 & 6,490 & 7,330 & 7,630 \\
5.47 & 6,510 & 7,330 & 7,660 \\
& 6,540 & 7,350 & 7,680 \\
5.40 & 6,590 & 7,400 & 7,730
\end{tabular}

\begin{tabular}{rrrr}
\hline & & & \\
& & Flow (cfs) & \\
\cline { 2 - 4 } Stage (ft) & 2005 & 2012 & 2014 \\
\hline 5.51 & 6,610 & 7,430 & 7,760 \\
5.52 & 6,640 & 7,450 & 7,790 \\
5.53 & 6,670 & 7,480 & 7,810 \\
5.54 & 6,690 & 7,500 & 7,840 \\
5.55 & 6,720 & 7,530 & 7,860 \\
5.56 & 6,740 & 7,550 & 7,890 \\
5.57 & 6,770 & 7,580 & 7,920 \\
5.58 & 6,800 & 7,610 & 7,940 \\
5.59 & 6,820 & 7,630 & 7,970 \\
5.60 & 6,850 & 7,660 & 8,000 \\
5.61 & 6,870 & 7,680 & 8,020 \\
5.62 & 6,900 & 7,710 & 8,050 \\
5.63 & 6,930 & 7,730 & 8,070 \\
5.64 & 6,950 & 7,760 & 8,100 \\
5.65 & 6,980 & 7,790 & 8,130 \\
5.66 & 7,010 & 7,810 & 8,150 \\
5.67 & 7,030 & 7,840 & 8,180 \\
5.68 & 7,060 & 7,860 & 8,210 \\
5.69 & 7,090 & 7,890 & 8,230 \\
5.70 & 7,110 & 7,890 & 8,260 \\
5.71 & 7,140 & 7,920 & 8,290 \\
5.72 & 7,170 & 7,940 & 8,310 \\
5.73 & 7,190 & 7,970 & 8,340 \\
5.74 & 7,220 & 7,990 & 8,370 \\
5.75 & 7,250 & 8,020 & 8,390 \\
5.76 & 7,280 & 8,050 & 8,420 \\
5.77 & 7,300 & 8,070 & 8,450 \\
5.78 & 7,330 & 8,100 & 8,470 \\
5.79 & 7,360 & 8,130 & 8,500 \\
5.80 & 7,380 & 8,150 & 8,530 \\
5.81 & 7,410 & 8,180 & 8,550 \\
5.82 & 7,440 & 8,210 & 8,580 \\
5.83 & 7,470 & 8,230 & 8,610 \\
5.84 & 7,490 & 8,260 & 8,630 \\
5.85 & 7,520 & 8,290 & 8,660 \\
& 7,550 & 8,310 & 8,690 \\
5.86 & 7,580 & 8,340 & 8,710 \\
5,610 & 8,370 & 8,740 \\
$5,6,630$ & 8,390 & 8,770 \\
5,660 & 8,420 & 8,790 \\
5,490 & 8,450 & 8,820
\end{tabular}




\begin{tabular}{rrrr}
\hline & & & \\
& & Flow (cfs) & \\
\cline { 2 - 4 } Stage (ft) & 2005 & 2012 & 2014 \\
\hline 5.92 & 7,720 & 8,470 & 8,850 \\
5.93 & 7,750 & 8,470 & 8,870 \\
5.94 & 7,770 & 8,500 & 8,900 \\
5.95 & 7,800 & 8,530 & 8,930 \\
5.96 & 7,830 & 8,550 & 8,960 \\
5.97 & 7,860 & 8,580 & 8,980 \\
5.98 & 7,890 & 8,610 & 9,010 \\
5.99 & 7,920 & 8,640 & 9,040 \\
6.00 & 7,940 & 8,660 & 9,060 \\
6.01 & 7,970 & 8,690 & 9,090 \\
6.02 & 8,000 & 8,720 & 9,120 \\
6.03 & 8,030 & 8,740 & 9,150 \\
6.04 & 8,060 & 8,770 & 9,170 \\
6.05 & 8,090 & 8,800 & 9,200 \\
6.06 & 8,120 & 8,830 & 9,230 \\
6.07 & 8,140 & 8,850 & 9,250 \\
6.08 & 8,170 & 8,880 & 9,280 \\
6.09 & 8,200 & 8,910 & 9,310 \\
6.10 & 8,230 & 8,940 & 9,340 \\
6.11 & 8,260 & 8,970 & 9,360 \\
6.12 & 8,290 & 8,990 & 9,390 \\
6.13 & 8,320 & 9,020 & 9,420 \\
6.14 & 8,350 & 9,050 & 9,450 \\
6.15 & 8,380 & 9,080 & 9,470 \\
6.16 & 8,410 & 9,080 & 9,500 \\
6.17 & 8,440 & 9,100 & 9,530 \\
6.18 & 8,460 & 9,130 & 9,560 \\
6.19 & 8,490 & 9,160 & 9,580 \\
6.20 & 8,520 & 9,190 & 9,610 \\
6.21 & 8,550 & 9,220 & 9,640 \\
6.22 & 8,580 & 9,240 & 9,670 \\
6.23 & 8,610 & 9,270 & 9,690 \\
6.24 & 8,640 & 9,300 & 9,720 \\
6.25 & 8,670 & 9,330 & 9,750 \\
6.26 & 8,700 & 9,360 & 9,780 \\
6.27 & 8,730 & 9,380 & 9,800 \\
6.28 & 8,760 & 9,410 & 9,830 \\
6.29 & 8,790 & 9,440 & 9,860 \\
6.30 & 8,820 & 9,470 & 9,890 \\
& 8,850 & 9,500 & 9,920 \\
& 8,880 & 9,530 & 9,940
\end{tabular}

\begin{tabular}{|c|c|c|c|}
\hline \multirow[b]{2}{*}{ Stage $(\mathrm{ft})$} & \multicolumn{3}{|c|}{ Flow (cfs) } \\
\hline & 2005 & 2012 & 2014 \\
\hline 6.33 & 8,910 & 9,560 & 9,970 \\
\hline 6.34 & 8,940 & 9,580 & 10,000 \\
\hline 6.35 & 8,970 & 9,610 & 10,000 \\
\hline 6.36 & 9,000 & 9,640 & 10,100 \\
\hline 6.37 & 9,030 & 9,670 & 10,100 \\
\hline 6.38 & 9,060 & 9,700 & 10,100 \\
\hline 6.39 & 9,090 & 9,700 & 10,100 \\
\hline 6.40 & 9,120 & 9,730 & 10,200 \\
\hline 6.41 & 9,140 & 9,760 & 10,200 \\
\hline 6.42 & 9,170 & 9,780 & 10,200 \\
\hline 6.43 & 9,200 & 9,810 & 10,200 \\
\hline 6.44 & 9,220 & 9,840 & 10,300 \\
\hline 6.45 & 9,250 & 9,870 & 10,300 \\
\hline 6.46 & 9,280 & 9,900 & 10,300 \\
\hline 6.47 & 9,300 & 9,930 & 10,400 \\
\hline 6.48 & 9,330 & 9,960 & 10,400 \\
\hline 6.49 & 9,360 & 9,990 & 10,400 \\
\hline 6.50 & 9,380 & 10,000 & 10,400 \\
\hline 6.51 & 9,410 & 10,000 & 10,500 \\
\hline 6.52 & 9,440 & 10,100 & 10,500 \\
\hline 6.53 & 9,460 & 10,100 & 10,500 \\
\hline 6.54 & 9,490 & 10,100 & 10,600 \\
\hline 6.55 & 9,520 & 10,200 & 10,600 \\
\hline 6.56 & 9,540 & 10,200 & 10,600 \\
\hline 6.57 & 9,570 & 10,200 & 10,600 \\
\hline 6.58 & 9,600 & 10,300 & 10,700 \\
\hline 6.59 & 9,620 & 10,300 & 10,700 \\
\hline 6.60 & 9,650 & 10,300 & 10,700 \\
\hline 6.61 & 9,680 & 10,300 & 10,800 \\
\hline 6.62 & 9,710 & 10,400 & 10,800 \\
\hline 6.63 & 9,730 & 10,400 & 10,800 \\
\hline 6.64 & 9,760 & 10,400 & 10,800 \\
\hline 6.65 & 9,790 & 10,500 & 10,900 \\
\hline 6.66 & 9,810 & 10,500 & 10,900 \\
\hline 6.67 & 9,840 & 10,500 & 10,900 \\
\hline 6.68 & 9,870 & 10,500 & 11,000 \\
\hline 6.69 & 9,900 & 10,600 & 11,000 \\
\hline 6.70 & 9,920 & 10,600 & 11,000 \\
\hline 6.71 & 9,950 & 10,600 & 11,000 \\
\hline 6.72 & 9,980 & 10,700 & 11,100 \\
\hline 6.73 & 10,000 & 10,700 & 11,100 \\
\hline
\end{tabular}




\begin{tabular}{rrrr}
\hline & & & \\
& & & \\
Stage (ft) & 2005 & 2012 & \\
\hline 6.74 & 10,000 & 10,700 & 11,100 \\
6.75 & 10,100 & 10,800 & 11,200 \\
6.76 & 10,100 & 10,800 & 11,200 \\
6.77 & 10,100 & 10,800 & 11,200 \\
6.78 & 10,100 & 10,800 & 11,200 \\
6.79 & 10,200 & 10,900 & 11,300 \\
6.80 & 10,200 & 10,900 & 11,300 \\
6.81 & 10,200 & 10,900 & 11,300 \\
6.82 & 10,300 & 11,000 & 11,400 \\
6.83 & 10,300 & 11,000 & 11,400 \\
6.84 & 10,300 & 11,000 & 11,400 \\
6.85 & 10,300 & 11,100 & 11,400 \\
6.86 & 10,400 & 11,100 & 11,500 \\
6.87 & 10,400 & 11,100 & 11,500 \\
6.88 & 10,400 & 11,100 & 11,500 \\
6.89 & 10,500 & 11,200 & 11,600 \\
6.90 & 10,500 & 11,200 & 11,600 \\
6.91 & 10,500 & 11,200 & 11,600 \\
6.92 & 10,500 & 11,300 & 11,600 \\
6.93 & 10,600 & 11,300 & 11,700 \\
6.94 & 10,600 & 11,300 & 11,700 \\
6.95 & 10,600 & 11,400 & 11,700 \\
7.96 & 10,600 & 11,400 & 11,800 \\
7.12 & 11,100 & 11,900 & 12,200 \\
6.97 & 10,700 & 11,400 & 11,800 \\
6.98 & 10,700 & 11,400 & 11,800 \\
6.99 & 10,700 & 11,500 & 11,800 \\
7.00 & 10,800 & 11,500 & 11,900 \\
7.01 & 10,800 & 11,500 & 11,900 \\
7.02 & 10,800 & 11,600 & 11,900 \\
7.03 & 10,800 & 11,600 & 12,000 \\
7.04 & 10,900 & 11,600 & 12,000 \\
7.05 & 10,900 & 11,700 & 12,000 \\
7.06 & 10,900 & 11,700 & 12,100 \\
7.07 & 11,000 & 11,700 & 12,100 \\
7.08 & 11,000 & 11,700 & 12,100 \\
& 11,000 & 11,800 & 12,100 \\
7.09 & 11,000 & 11,800 & 12,200 \\
7.100 & 11,900 & 12,300
\end{tabular}

\begin{tabular}{|c|c|c|c|}
\hline \multirow[b]{2}{*}{ Stage $(\mathrm{ft})$} & \multicolumn{3}{|c|}{ Flow (cfs) } \\
\hline & 2005 & 2012 & 2014 \\
\hline 7.15 & 11,200 & 12,000 & 12,300 \\
\hline 7.16 & 11,200 & 12,000 & 12,300 \\
\hline 7.17 & 11,200 & 12,000 & 12,400 \\
\hline 7.18 & 11,300 & 12,000 & 12,400 \\
\hline 7.19 & 11,300 & 12,100 & 12,400 \\
\hline 7.20 & 11,300 & 12,100 & 12,500 \\
\hline 7.21 & 11,400 & 12,100 & 12,500 \\
\hline 7.22 & 11,400 & 12,200 & 12,500 \\
\hline 7.23 & 11,400 & 12,200 & 12,600 \\
\hline 7.24 & 11,500 & 12,200 & 12,600 \\
\hline 7.25 & 11,500 & 12,300 & 12,600 \\
\hline 7.26 & 11,500 & 12,300 & 12,600 \\
\hline 7.27 & 11,500 & 12,300 & 12,700 \\
\hline 7.28 & 11,600 & 12,300 & 12,700 \\
\hline 7.29 & 11,600 & 12,400 & 12,700 \\
\hline 7.30 & 11,600 & 12,400 & 12,800 \\
\hline 7.31 & 11,700 & 12,400 & 12,800 \\
\hline 7.32 & 11,700 & 12,500 & 12,800 \\
\hline 7.33 & 11,700 & 12,500 & 12,800 \\
\hline 7.34 & 11,700 & 12,500 & 12,900 \\
\hline 7.35 & 11,800 & 12,600 & 12,900 \\
\hline 7.36 & 11,800 & 12,600 & 12,900 \\
\hline 7.37 & 11,800 & 12,600 & 13,000 \\
\hline 7.38 & 11,900 & 12,600 & 13,000 \\
\hline 7.39 & 11,900 & 12,700 & 13,000 \\
\hline 7.40 & 11,900 & 12,700 & 13,100 \\
\hline 7.41 & 12,000 & 12,700 & 13,100 \\
\hline 7.42 & 12,000 & 12,800 & 13,100 \\
\hline 7.43 & 12,000 & 12,800 & 13,100 \\
\hline 7.44 & 12,000 & 12,800 & 13,200 \\
\hline 7.45 & 12,100 & 12,900 & 13,200 \\
\hline 7.46 & 12,100 & 12,900 & 13,200 \\
\hline 7.47 & 12,100 & 12,900 & 13,300 \\
\hline 7.48 & 12,200 & 12,900 & 13,300 \\
\hline 7.49 & 12,200 & 13,000 & 13,300 \\
\hline 7.50 & 12,200 & 13,000 & 13,400 \\
\hline 7.51 & 12,300 & 13,000 & 13,400 \\
\hline 7.52 & 12,300 & 13,100 & 13,400 \\
\hline 7.53 & 12,300 & 13,100 & 13,400 \\
\hline 7.54 & 12,300 & 13,100 & 13,500 \\
\hline 7.55 & 12,400 & 13,100 & 13,500 \\
\hline
\end{tabular}




\begin{tabular}{|c|c|c|c|}
\hline \multirow[b]{2}{*}{ Stage $(\mathrm{ft})$} & \multicolumn{3}{|c|}{ Flow (cfs) } \\
\hline & 2005 & 2012 & 2014 \\
\hline 7.56 & 12,400 & 13,200 & 13,500 \\
\hline 7.57 & 12,400 & 13,200 & 13,600 \\
\hline 7.58 & 12,500 & 13,200 & 13,600 \\
\hline 7.59 & 12,500 & 13,300 & 13,600 \\
\hline 7.60 & 12,500 & 13,300 & 13,700 \\
\hline 7.61 & 12,600 & 13,300 & 13,700 \\
\hline 7.62 & 12,600 & 13,300 & 13,700 \\
\hline 7.63 & 12,600 & 13,400 & 13,700 \\
\hline 7.64 & 12,700 & 13,400 & 13,800 \\
\hline 7.65 & 12,700 & 13,400 & 13,800 \\
\hline 7.66 & 12,700 & 13,500 & 13,800 \\
\hline 7.67 & 12,700 & 13,500 & 13,900 \\
\hline 7.68 & 12,800 & 13,500 & 13,900 \\
\hline 7.69 & 12,800 & 13,500 & 13,900 \\
\hline 7.70 & 12,800 & 13,600 & 14,000 \\
\hline 7.71 & 12,900 & 13,600 & 14,000 \\
\hline 7.72 & 12,900 & 13,600 & 14,000 \\
\hline 7.73 & 12,900 & 13,700 & 14,000 \\
\hline 7.74 & 13,000 & 13,700 & 14,100 \\
\hline 7.75 & 13,000 & 13,700 & 14,100 \\
\hline 7.76 & 13,000 & 13,800 & 14,100 \\
\hline 7.77 & 13,100 & 13,800 & 14,200 \\
\hline 7.78 & 13,100 & 13,800 & 14,200 \\
\hline 7.79 & 13,100 & 13,800 & 14,200 \\
\hline 7.80 & 13,100 & 13,900 & 14,300 \\
\hline 7.81 & 13,200 & 13,900 & 14,300 \\
\hline 7.82 & 13,200 & 13,900 & 14,300 \\
\hline 7.83 & 13,200 & 14,000 & 14,400 \\
\hline 7.84 & 13,300 & 14,000 & 14,400 \\
\hline 7.85 & 13,300 & 14,000 & 14,400 \\
\hline 7.86 & 13,300 & 14,000 & 14,400 \\
\hline 7.87 & 13,400 & 14,100 & 14,500 \\
\hline 7.88 & 13,400 & 14,100 & 14,500 \\
\hline 7.89 & 13,400 & 14,100 & 14,500 \\
\hline 7.90 & 13,500 & 14,200 & 14,600 \\
\hline 7.91 & 13,500 & 14,200 & 14,600 \\
\hline 7.92 & 13,500 & 14,200 & 14,600 \\
\hline 7.93 & 13,600 & 14,300 & 14,700 \\
\hline 7.94 & 13,600 & 14,300 & 14,700 \\
\hline 7.95 & 13,600 & 14,300 & 14,700 \\
\hline 7.96 & 13,600 & 14,300 & 14,800 \\
\hline
\end{tabular}

\begin{tabular}{|c|c|c|c|}
\hline \multirow[b]{2}{*}{ Stage $(\mathrm{ft})$} & \multicolumn{3}{|c|}{ Flow (cfs) } \\
\hline & 2005 & 2012 & 2014 \\
\hline 7.97 & 13,700 & 14,400 & 14,800 \\
\hline 7.98 & 13,700 & 14,400 & 14,800 \\
\hline 7.99 & 13,700 & 14,400 & 14,800 \\
\hline 8.00 & 13,800 & 14,500 & 14,900 \\
\hline 8.01 & 13,800 & 14,500 & 14,900 \\
\hline 8.02 & 13,800 & 14,500 & 14,900 \\
\hline 8.03 & 13,900 & 14,600 & 15,000 \\
\hline 8.04 & 13,900 & 14,600 & 15,000 \\
\hline 8.05 & 13,900 & 14,600 & 15,000 \\
\hline 8.06 & 14,000 & 14,600 & 15,100 \\
\hline 8.07 & 14,000 & 14,700 & 15,100 \\
\hline 8.08 & 14,000 & 14,700 & 15,100 \\
\hline 8.09 & 14,100 & 14,700 & 15,200 \\
\hline 8.10 & 14,100 & 14,800 & 15,200 \\
\hline 8.11 & 14,100 & 14,800 & 15,200 \\
\hline 8.12 & 14,200 & 14,800 & 15,200 \\
\hline 8.13 & 14,200 & 14,900 & 15,300 \\
\hline 8.14 & 14,200 & 14,900 & 15,300 \\
\hline 8.15 & 14,300 & 14,900 & 15,300 \\
\hline 8.16 & 14,300 & 15,000 & 15,400 \\
\hline 8.17 & 14,300 & 15,000 & 15,400 \\
\hline 8.18 & 14,400 & 15,000 & 15,400 \\
\hline 8.19 & 14,400 & 15,000 & 15,500 \\
\hline 8.20 & 14,400 & 15,100 & 15,500 \\
\hline 8.21 & 14,500 & 15,100 & 15,500 \\
\hline 8.22 & 14,500 & 15,100 & 15,600 \\
\hline 8.23 & 14,500 & 15,200 & 15,600 \\
\hline 8.24 & 14,600 & 15,200 & 15,600 \\
\hline 8.25 & 14,600 & 15,200 & 15,700 \\
\hline 8.26 & 14,600 & 15,300 & 15,700 \\
\hline 8.27 & 14,600 & 15,300 & 15,700 \\
\hline 8.28 & 14,700 & 15,300 & 15,700 \\
\hline 8.29 & 14,700 & 15,400 & 15,800 \\
\hline 8.30 & 14,700 & 15,400 & 15,800 \\
\hline 8.31 & 14,800 & 15,400 & 15,800 \\
\hline 8.32 & 14,800 & 15,400 & 15,900 \\
\hline 8.33 & 14,800 & 15,500 & 15,900 \\
\hline 8.34 & 14,900 & 15,500 & 15,900 \\
\hline 8.35 & 14,900 & 15,500 & 16,000 \\
\hline 8.36 & 14,900 & 15,600 & 16,000 \\
\hline 8.37 & 15,000 & 15,600 & 16,000 \\
\hline
\end{tabular}




\begin{tabular}{|c|c|c|c|}
\hline \multirow[b]{2}{*}{ Stage $(\mathrm{ft})$} & \multicolumn{3}{|c|}{ Flow (cfs) } \\
\hline & 2005 & 2012 & 2014 \\
\hline 8.38 & 15,000 & 15,600 & 16,100 \\
\hline 8.39 & 15,000 & 15,700 & 16,100 \\
\hline 8.40 & 15,100 & 15,700 & 16,100 \\
\hline 8.41 & 15,100 & 15,700 & 16,200 \\
\hline 8.42 & 15,100 & 15,800 & 16,200 \\
\hline 8.43 & 15,200 & 15,800 & 16,200 \\
\hline 8.44 & 15,200 & 15,800 & 16,200 \\
\hline 8.45 & 15,200 & 15,800 & 16,300 \\
\hline 8.46 & 15,300 & 15,900 & 16,300 \\
\hline 8.47 & 15,300 & 15,900 & 16,300 \\
\hline 8.48 & 15,300 & 15,900 & 16,400 \\
\hline 8.49 & 15,400 & 16,000 & 16,400 \\
\hline 8.50 & 15,400 & 16,000 & 16,400 \\
\hline 8.51 & 15,400 & 16,000 & 16,500 \\
\hline 8.52 & 15,500 & 16,100 & 16,500 \\
\hline 8.53 & 15,500 & 16,100 & 16,500 \\
\hline 8.54 & 15,500 & 16,100 & 16,600 \\
\hline 8.55 & 15,600 & 16,200 & 16,600 \\
\hline 8.56 & 15,600 & 16,200 & 16,600 \\
\hline 8.57 & 15,600 & 16,200 & 16,700 \\
\hline 8.58 & 15,700 & 16,300 & 16,700 \\
\hline 8.59 & 15,700 & 16,300 & 16,700 \\
\hline 8.60 & 15,700 & 16,300 & 16,800 \\
\hline 8.61 & 15,800 & 16,300 & 16,800 \\
\hline 8.62 & 15,800 & 16,400 & 16,800 \\
\hline 8.63 & 15,800 & 16,400 & 16,800 \\
\hline 8.64 & 15,900 & 16,400 & 16,900 \\
\hline 8.65 & 15,900 & 16,500 & 16,900 \\
\hline 8.66 & 16,000 & 16,500 & 16,900 \\
\hline 8.67 & 16,000 & 16,500 & 17,000 \\
\hline 8.68 & 16,000 & 16,600 & 17,000 \\
\hline 8.69 & 16,100 & 16,600 & 17,000 \\
\hline 8.70 & 16,100 & 16,600 & 17,100 \\
\hline 8.71 & 16,100 & 16,700 & 17,100 \\
\hline 8.72 & 16,200 & 16,700 & 17,100 \\
\hline 8.73 & 16,200 & 16,700 & 17,200 \\
\hline 8.74 & 16,200 & 16,800 & 17,200 \\
\hline 8.75 & 16,300 & 16,800 & 17,200 \\
\hline 8.76 & 16,300 & 16,800 & 17,300 \\
\hline 8.77 & 16,300 & 16,900 & 17,300 \\
\hline 8.78 & 16,400 & 16,900 & 17,300 \\
\hline
\end{tabular}

\begin{tabular}{|c|c|c|c|}
\hline \multirow[b]{2}{*}{ Stage $(\mathrm{ft})$} & \multicolumn{3}{|c|}{ Flow (cfs) } \\
\hline & 2005 & 2012 & 2014 \\
\hline 8.79 & 16,400 & 16,900 & 17,400 \\
\hline 8.80 & 16,400 & 17,000 & 17,400 \\
\hline 8.81 & 16,500 & 17,000 & 17,400 \\
\hline 8.82 & 16,500 & 17,000 & 17,500 \\
\hline 8.83 & 16,500 & 17,100 & 17,500 \\
\hline 8.84 & 16,600 & 17,100 & 17,500 \\
\hline 8.85 & 16,600 & 17,100 & 17,600 \\
\hline 8.86 & 16,600 & 17,100 & 17,600 \\
\hline 8.87 & 16,700 & 17,200 & 17,600 \\
\hline 8.88 & 16,700 & 17,200 & 17,700 \\
\hline 8.89 & 16,700 & 17,200 & 17,700 \\
\hline 8.90 & 16,800 & 17,300 & 17,700 \\
\hline 8.91 & 16,800 & 17,300 & 17,700 \\
\hline 8.92 & 16,800 & 17,300 & 17,800 \\
\hline 8.93 & 16,900 & 17,400 & 17,800 \\
\hline 8.94 & 16,900 & 17,400 & 17,800 \\
\hline 8.95 & 17,000 & 17,400 & 17,900 \\
\hline 8.96 & 17,000 & 17,500 & 17,900 \\
\hline 8.97 & 17,000 & 17,500 & 17,900 \\
\hline 8.98 & 17,100 & 17,500 & 18,000 \\
\hline 8.99 & 17,100 & 17,600 & 18,000 \\
\hline 9.00 & 17,100 & 17,600 & 18,000 \\
\hline 9.01 & 17,200 & 17,600 & 18,100 \\
\hline 9.02 & 17,200 & 17,700 & 18,100 \\
\hline 9.03 & 17,200 & 17,700 & 18,100 \\
\hline 9.04 & 17,300 & 17,700 & 18,200 \\
\hline 9.05 & 17,300 & 17,800 & 18,200 \\
\hline 9.06 & 17,300 & 17,800 & 18,200 \\
\hline 9.07 & 17,400 & 17,800 & 18,300 \\
\hline 9.08 & 17,400 & 17,900 & 18,300 \\
\hline 9.09 & 17,400 & 17,900 & 18,300 \\
\hline 9.10 & 17,500 & 17,900 & 18,400 \\
\hline 9.11 & 17,500 & 18,000 & 18,400 \\
\hline 9.12 & 17,600 & 18,000 & 18,400 \\
\hline 9.13 & 17,600 & 18,000 & 18,500 \\
\hline 9.14 & 17,600 & 18,100 & 18,500 \\
\hline 9.15 & 17,700 & 18,100 & 18,500 \\
\hline 9.16 & 17,700 & 18,100 & 18,600 \\
\hline 9.17 & 17,700 & 18,200 & 18,600 \\
\hline 9.18 & 17,800 & 18,200 & 18,600 \\
\hline 9.19 & 17,800 & 18,200 & 18,700 \\
\hline
\end{tabular}




\begin{tabular}{|c|c|c|c|}
\hline \multirow[b]{2}{*}{ Stage $(\mathrm{ft})$} & \multicolumn{3}{|c|}{ Flow (cfs) } \\
\hline & 2005 & 2012 & 2014 \\
\hline 9.20 & 17,800 & 18,300 & 18,700 \\
\hline 9.21 & 17,900 & 18,300 & 18,700 \\
\hline 9.22 & 17,900 & 18,300 & 18,800 \\
\hline 9.23 & 17,900 & 18,400 & 18,800 \\
\hline 9.24 & 18,000 & 18,400 & 18,800 \\
\hline 9.25 & 18,000 & 18,400 & 18,900 \\
\hline 9.26 & 18,100 & 18,500 & 18,900 \\
\hline 9.27 & 18,100 & 18,500 & 18,900 \\
\hline 9.28 & 18,100 & 18,500 & 19,000 \\
\hline 9.29 & 18,200 & 18,600 & 19,000 \\
\hline 9.30 & 18,200 & 18,600 & 19,000 \\
\hline 9.31 & 18,200 & 18,600 & 19,000 \\
\hline 9.32 & 18,300 & 18,700 & 19,100 \\
\hline 9.33 & 18,300 & 18,700 & 19,100 \\
\hline 9.34 & 18,300 & 18,700 & 19,100 \\
\hline 9.35 & 18,400 & 18,800 & 19,200 \\
\hline 9.36 & 18,400 & 18,800 & 19,200 \\
\hline 9.37 & 18,500 & 18,800 & 19,200 \\
\hline 9.38 & 18,500 & 18,900 & 19,300 \\
\hline 9.39 & 18,500 & 18,900 & 19,300 \\
\hline 9.40 & 18,600 & 18,900 & 19,300 \\
\hline 9.41 & 18,600 & 19,000 & 19,400 \\
\hline 9.42 & 18,600 & 19,000 & 19,400 \\
\hline 9.43 & 18,700 & 19,000 & 19,400 \\
\hline 9.44 & 18,700 & 19,100 & 19,500 \\
\hline 9.45 & 18,700 & 19,100 & 19,500 \\
\hline 9.46 & 18,800 & 19,100 & 19,500 \\
\hline 9.47 & 18,800 & 19,200 & 19,600 \\
\hline 9.48 & 18,900 & 19,200 & 19,600 \\
\hline 9.49 & 18,900 & 19,200 & 19,600 \\
\hline 9.50 & 18,900 & 19,300 & 19,700 \\
\hline 9.51 & 19,000 & 19,300 & 19,700 \\
\hline 9.52 & 19,000 & 19,300 & 19,700 \\
\hline 9.53 & 19,000 & 19,400 & 19,800 \\
\hline 9.54 & 19,100 & 19,400 & 19,800 \\
\hline 9.55 & 19,100 & 19,400 & 19,800 \\
\hline 9.56 & 19,200 & 19,500 & 19,900 \\
\hline 9.57 & 19,200 & 19,500 & 19,900 \\
\hline 9.58 & 19,200 & 19,500 & 19,900 \\
\hline 9.59 & 19,300 & 19,600 & 20,000 \\
\hline 9.60 & 19,300 & 19,600 & 20,000 \\
\hline
\end{tabular}

\begin{tabular}{|c|c|c|c|}
\hline \multirow[b]{2}{*}{ Stage (ft) } & \multicolumn{3}{|c|}{ Flow (cfs) } \\
\hline & 2005 & 2012 & 2014 \\
\hline 9.61 & 19,300 & 19,600 & 20,000 \\
\hline 9.62 & 19,400 & 19,700 & 20,100 \\
\hline 9.63 & 19,400 & 19,700 & 20,100 \\
\hline 9.64 & 19,500 & 19,700 & 20,100 \\
\hline 9.65 & 19,500 & 19,800 & 20,200 \\
\hline 9.66 & 19,500 & 19,800 & 20,200 \\
\hline 9.67 & 19,600 & 19,800 & 20,200 \\
\hline 9.68 & 19,600 & 19,900 & 20,300 \\
\hline 9.69 & 19,600 & 19,900 & 20,300 \\
\hline 9.70 & 19,700 & 19,900 & 20,300 \\
\hline 9.71 & 19,700 & 20,000 & 20,400 \\
\hline 9.72 & 19,800 & 20,000 & 20,400 \\
\hline 9.73 & 19,800 & 20,000 & 20,400 \\
\hline 9.74 & 19,800 & 20,100 & 20,500 \\
\hline 9.75 & 19,900 & 20,100 & 20,500 \\
\hline 9.76 & 19,900 & 20,100 & 20,500 \\
\hline 9.77 & 19,900 & 20,200 & 20,600 \\
\hline 9.78 & 20,000 & 20,200 & 20,600 \\
\hline 9.79 & 20,000 & 20,200 & 20,600 \\
\hline 9.80 & 20,100 & 20,300 & 20,700 \\
\hline 9.81 & 20,100 & 20,300 & 20,700 \\
\hline 9.82 & 20,100 & 20,300 & 20,700 \\
\hline 9.83 & 20,200 & 20,400 & 20,800 \\
\hline 9.84 & 20,200 & 20,400 & 20,800 \\
\hline 9.85 & 20,200 & 20,500 & 20,800 \\
\hline 9.86 & 20,300 & 20,500 & 20,900 \\
\hline 9.87 & 20,300 & 20,500 & 20,900 \\
\hline 9.88 & 20,400 & 20,600 & 20,900 \\
\hline 9.89 & 20,400 & 20,600 & 21,000 \\
\hline 9.90 & 20,400 & 20,600 & 21,000 \\
\hline 9.91 & 20,500 & 20,700 & 21,000 \\
\hline 9.92 & 20,500 & 20,700 & 21,100 \\
\hline 9.93 & 20,500 & 20,700 & 21,100 \\
\hline 9.94 & 20,600 & 20,800 & 21,100 \\
\hline 9.95 & 20,600 & 20,800 & 21,200 \\
\hline 9.96 & 20,700 & 20,800 & 21,200 \\
\hline 9.97 & 20,700 & 20,900 & 21,200 \\
\hline 9.98 & 20,700 & 20,900 & 21,300 \\
\hline 9.99 & 20,800 & 20,900 & 21,300 \\
\hline 10.00 & 20,800 & 21,000 & 21,400 \\
\hline 10.01 & 20,900 & 21,000 & 21,400 \\
\hline
\end{tabular}




\begin{tabular}{|c|c|c|c|}
\hline \multirow[b]{2}{*}{ Stage $(\mathrm{ft})$} & \multicolumn{3}{|c|}{ Flow (cfs) } \\
\hline & 2005 & 2012 & 2014 \\
\hline 10.02 & 20,900 & 21,000 & 21,400 \\
\hline 10.03 & 20,900 & 21,100 & 21,500 \\
\hline 10.04 & 21,000 & 21,100 & 21,500 \\
\hline 10.05 & 21,000 & 21,100 & 21,500 \\
\hline 10.06 & 21,000 & 21,200 & 21,600 \\
\hline 10.07 & 21,100 & 21,200 & 21,600 \\
\hline 10.08 & 21,100 & 21,300 & 21,600 \\
\hline 10.09 & 21,200 & 21,300 & 21,700 \\
\hline 10.10 & 21,200 & 21,300 & 21,700 \\
\hline 10.11 & 21,200 & 21,400 & 21,700 \\
\hline 10.12 & 21,300 & 21,400 & 21,800 \\
\hline 10.13 & 21,300 & 21,400 & 21,800 \\
\hline 10.14 & 21,400 & 21,500 & 21,800 \\
\hline 10.15 & 21,400 & 21,500 & 21,900 \\
\hline 10.16 & 21,400 & 21,500 & 21,900 \\
\hline 10.17 & 21,500 & 21,600 & 21,900 \\
\hline 10.18 & 21,500 & 21,600 & 22,000 \\
\hline 10.19 & 21,600 & 21,600 & 22,000 \\
\hline 10.20 & 21,600 & 21,700 & 22,000 \\
\hline 10.21 & 21,600 & 21,700 & 22,100 \\
\hline 10.22 & 21,700 & 21,700 & 22,100 \\
\hline 10.23 & 21,700 & 21,800 & 22,100 \\
\hline 10.24 & 21,700 & 21,800 & 22,200 \\
\hline 10.25 & 21,800 & 21,900 & 22,200 \\
\hline 10.26 & 21,800 & 21,900 & 22,200 \\
\hline 10.27 & 21,900 & 21,900 & 22,300 \\
\hline 10.28 & 21,900 & 22,000 & 22,300 \\
\hline 10.29 & 21,900 & 22,000 & 22,300 \\
\hline 10.30 & 22,000 & 22,000 & 22,400 \\
\hline 10.31 & 22,000 & 22,100 & 22,400 \\
\hline 10.32 & 22,100 & 22,100 & 22,400 \\
\hline 10.33 & 22,100 & 22,100 & 22,500 \\
\hline 10.34 & 22,100 & 22,200 & 22,500 \\
\hline 10.35 & 22,200 & 22,200 & 22,500 \\
\hline 10.36 & 22,200 & 22,200 & 22,600 \\
\hline 10.37 & 22,300 & 22,300 & 22,600 \\
\hline 10.38 & 22,300 & 22,300 & 22,600 \\
\hline 10.39 & 22,300 & 22,300 & 22,700 \\
\hline 10.40 & 22,400 & 22,400 & 22,700 \\
\hline 10.41 & 22,400 & 22,400 & 22,700 \\
\hline 10.42 & 22,500 & 22,500 & 22,800 \\
\hline
\end{tabular}

\begin{tabular}{|c|c|c|c|}
\hline \multirow[b]{2}{*}{ Stage $(\mathrm{ft})$} & \multicolumn{3}{|c|}{ Flow (cfs) } \\
\hline & 2005 & 2012 & 2014 \\
\hline 10.43 & 22,500 & 22,500 & 22,800 \\
\hline 10.44 & 22,500 & 22,500 & 22,900 \\
\hline 10.45 & 22,600 & 22,600 & 22,900 \\
\hline 10.46 & 22,600 & 22,600 & 22,900 \\
\hline 10.47 & 22,700 & 22,600 & 23,000 \\
\hline 10.48 & 22,700 & 22,700 & 23,000 \\
\hline 10.49 & 22,700 & 22,700 & 23,000 \\
\hline 10.50 & 22,800 & 22,700 & 23,100 \\
\hline 10.51 & 22,800 & 22,800 & 23,100 \\
\hline 10.52 & 22,900 & 22,800 & 23,100 \\
\hline 10.53 & 22,900 & 22,900 & 23,200 \\
\hline 10.54 & 22,900 & 22,900 & 23,200 \\
\hline 10.55 & 23,000 & 22,900 & 23,200 \\
\hline 10.56 & 23,000 & 23,000 & 23,300 \\
\hline 10.57 & 23,100 & 23,000 & 23,300 \\
\hline 10.58 & 23,100 & 23,000 & 23,300 \\
\hline 10.59 & 23,100 & 23,100 & 23,400 \\
\hline 10.60 & 23,200 & 23,100 & 23,400 \\
\hline 10.61 & 23,200 & 23,100 & 23,400 \\
\hline 10.62 & 23,300 & 23,200 & 23,500 \\
\hline 10.63 & 23,300 & 23,200 & 23,500 \\
\hline 10.64 & 23,300 & 23,300 & 23,500 \\
\hline 10.65 & 23,400 & 23,300 & 23,600 \\
\hline 10.66 & 23,400 & 23,300 & 23,600 \\
\hline 10.67 & 23,500 & 23,400 & 23,600 \\
\hline 10.68 & 23,500 & 23,400 & 23,700 \\
\hline 10.69 & 23,500 & 23,400 & 23,700 \\
\hline 10.70 & 23,600 & 23,500 & 23,800 \\
\hline 10.71 & 23,600 & 23,500 & 23,800 \\
\hline 10.72 & 23,700 & 23,500 & 23,800 \\
\hline 10.73 & 23,700 & 23,600 & 23,900 \\
\hline 10.74 & 23,800 & 23,600 & 23,900 \\
\hline 10.75 & 23,800 & 23,700 & 23,900 \\
\hline 10.76 & 23,800 & 23,700 & 24,000 \\
\hline 10.77 & 23,900 & 23,700 & 24,000 \\
\hline 10.78 & 23,900 & 23,800 & 24,000 \\
\hline 10.79 & 24,000 & 23,800 & 24,100 \\
\hline 10.80 & 24,000 & 23,800 & 24,100 \\
\hline 10.81 & 24,000 & 23,900 & 24,100 \\
\hline 10.82 & 24,100 & 23,900 & 24,200 \\
\hline 10.83 & 24,100 & 23,900 & 24,200 \\
\hline
\end{tabular}




\begin{tabular}{|c|c|c|c|}
\hline \multirow[b]{2}{*}{ Stage (ft) } & \multicolumn{3}{|c|}{ Flow (cfs) } \\
\hline & 2005 & 2012 & 2014 \\
\hline 10.84 & 24,100 & 24,000 & 24,200 \\
\hline 10.85 & 24,200 & 24,000 & 24,300 \\
\hline 10.86 & 24,200 & 24,100 & 24,300 \\
\hline 10.87 & 24,300 & 24,100 & 24,300 \\
\hline 10.88 & 24,300 & 24,100 & 24,400 \\
\hline 10.89 & 24,300 & 24,200 & 24,400 \\
\hline 10.90 & 24,400 & 24,200 & 24,500 \\
\hline 10.91 & 24,400 & 24,200 & 24,500 \\
\hline 10.92 & 24,400 & 24,300 & 24,500 \\
\hline 10.93 & 24,500 & 24,300 & 24,600 \\
\hline 10.94 & 24,500 & 24,400 & 24,600 \\
\hline 10.95 & 24,600 & 24,400 & 24,600 \\
\hline 10.96 & 24,600 & 24,400 & 24,700 \\
\hline 10.97 & 24,600 & 24,500 & 24,700 \\
\hline 10.98 & 24,700 & 24,500 & 24,700 \\
\hline 10.99 & 24,700 & 24,500 & 24,800 \\
\hline 11.00 & 24,700 & 24,600 & 24,800 \\
\hline 11.01 & 24,800 & 24,600 & 24,800 \\
\hline 11.02 & 24,800 & 24,600 & 24,900 \\
\hline 11.03 & 24,900 & 24,700 & 24,900 \\
\hline 11.04 & 24,900 & 24,700 & 24,900 \\
\hline 11.05 & 24,900 & 24,800 & 25,000 \\
\hline 11.06 & 25,000 & 24,800 & 25,000 \\
\hline 11.07 & 25,000 & 24,800 & 25,000 \\
\hline 11.08 & 25,000 & 24,900 & 25,100 \\
\hline 11.09 & 25,100 & 24,900 & 25,100 \\
\hline 11.10 & 25,100 & 24,900 & 25,200 \\
\hline 11.11 & 25,200 & 25,000 & 25,200 \\
\hline 11.12 & 25,200 & 25,000 & 25,200 \\
\hline 11.13 & 25,200 & 25,100 & 25,300 \\
\hline 11.14 & 25,300 & 25,100 & 25,300 \\
\hline 11.15 & 25,300 & 25,100 & 25,300 \\
\hline 11.16 & 25,300 & 25,200 & 25,400 \\
\hline 11.17 & 25,400 & 25,200 & 25,400 \\
\hline 11.18 & 25,400 & 25,200 & 25,400 \\
\hline 11.19 & 25,500 & 25,300 & 25,500 \\
\hline 11.20 & 25,500 & 25,300 & 25,500 \\
\hline 11.21 & 25,500 & 25,400 & 25,500 \\
\hline 11.22 & 25,600 & 25,400 & 25,600 \\
\hline 11.23 & 25,600 & 25,400 & 25,600 \\
\hline 11.24 & 25,700 & 25,500 & 25,600 \\
\hline
\end{tabular}

\begin{tabular}{|c|c|c|c|}
\hline \multirow[b]{2}{*}{ Stage $(\mathrm{ft})$} & \multicolumn{3}{|c|}{ Flow (cfs) } \\
\hline & 2005 & 2012 & 2014 \\
\hline 11.25 & 25,700 & 25,500 & 25,700 \\
\hline 11.26 & 25,700 & 25,500 & 25,700 \\
\hline 11.27 & 25,800 & 25,600 & 25,800 \\
\hline 11.28 & 25,800 & 25,600 & 25,800 \\
\hline 11.29 & 25,800 & 25,700 & 25,800 \\
\hline 11.30 & 25,900 & 25,700 & 25,900 \\
\hline 11.31 & 25,900 & 25,700 & 25,900 \\
\hline 11.32 & 26,000 & 25,800 & 25,900 \\
\hline 11.33 & 26,000 & 25,800 & 26,000 \\
\hline 11.34 & 26,000 & 25,900 & 26,000 \\
\hline 11.35 & 26,100 & 25,900 & 26,000 \\
\hline 11.36 & 26,100 & 25,900 & 26,100 \\
\hline 11.37 & 26,100 & 26,000 & 26,100 \\
\hline 11.38 & 26,200 & 26,000 & 26,100 \\
\hline 11.39 & 26,200 & 26,000 & 26,200 \\
\hline 11.40 & 26,300 & 26,100 & 26,200 \\
\hline 11.41 & 26,300 & 26,100 & 26,300 \\
\hline 11.42 & 26,300 & 26,200 & 26,300 \\
\hline 11.43 & 26,400 & 26,200 & 26,300 \\
\hline 11.44 & 26,400 & 26,200 & 26,400 \\
\hline 11.45 & 26,500 & 26,300 & 26,400 \\
\hline 11.46 & 26,500 & 26,300 & 26,400 \\
\hline 11.47 & 26,500 & 26,300 & 26,500 \\
\hline 11.48 & 26,600 & 26,400 & 26,500 \\
\hline 11.49 & 26,600 & 26,400 & 26,500 \\
\hline 11.50 & 26,600 & 26,500 & 26,600 \\
\hline 11.51 & 26,700 & 26,500 & 26,600 \\
\hline 11.52 & 26,700 & 26,500 & 26,600 \\
\hline 11.53 & 26,800 & 26,600 & 26,700 \\
\hline 11.54 & 26,800 & 26,600 & 26,700 \\
\hline 11.55 & 26,800 & 26,700 & 26,800 \\
\hline 11.56 & 26,900 & 26,700 & 26,800 \\
\hline 11.57 & 26,900 & 26,700 & 26,800 \\
\hline 11.58 & 27,000 & 26,800 & 26,900 \\
\hline 11.59 & 27,000 & 26,800 & 26,900 \\
\hline 11.60 & 27,000 & 26,800 & 26,900 \\
\hline 11.61 & 27,100 & 26,900 & 27,000 \\
\hline 11.62 & 27,100 & 26,900 & 27,000 \\
\hline 11.63 & 27,200 & 27,000 & 27,000 \\
\hline 11.64 & 27,200 & 27,000 & 27,100 \\
\hline 11.65 & 27,200 & 27,000 & 27,100 \\
\hline
\end{tabular}




\begin{tabular}{|c|c|c|c|}
\hline \multirow[b]{2}{*}{ Stage $(\mathrm{ft})$} & \multicolumn{3}{|c|}{ Flow (cfs) } \\
\hline & 2005 & 2012 & 2014 \\
\hline 11.66 & 27,300 & 27,100 & 27,200 \\
\hline 11.67 & 27,300 & 27,100 & 27,200 \\
\hline 11.68 & 27,300 & 27,200 & 27,200 \\
\hline 11.69 & 27,400 & 27,200 & 27,300 \\
\hline 11.70 & 27,400 & 27,200 & 27,300 \\
\hline 11.71 & 27,500 & 27,300 & 27,300 \\
\hline 11.72 & 27,500 & 27,300 & 27,400 \\
\hline 11.73 & 27,500 & 27,300 & 27,400 \\
\hline 11.74 & 27,600 & 27,400 & 27,400 \\
\hline 11.75 & 27,600 & 27,400 & 27,500 \\
\hline 11.76 & 27,700 & 27,500 & 27,500 \\
\hline 11.77 & 27,700 & 27,500 & 27,500 \\
\hline 11.78 & 27,700 & 27,500 & 27,600 \\
\hline 11.79 & 27,800 & 27,600 & 27,600 \\
\hline 11.80 & 27,800 & 27,600 & 27,700 \\
\hline 11.81 & 27,900 & 27,700 & 27,700 \\
\hline 11.82 & 27,900 & 27,700 & 27,700 \\
\hline 11.83 & 27,900 & 27,700 & 27,800 \\
\hline 11.84 & 28,000 & 27,800 & 27,800 \\
\hline 11.85 & 28,000 & 27,800 & 27,800 \\
\hline 11.86 & 28,100 & 27,900 & 27,900 \\
\hline 11.87 & 28,100 & 27,900 & 27,900 \\
\hline 11.88 & 28,100 & 27,900 & 27,900 \\
\hline 11.89 & 28,200 & 28,000 & 28,000 \\
\hline 11.90 & 28,200 & 28,000 & 28,000 \\
\hline 11.91 & 28,200 & 28,000 & 28,100 \\
\hline 11.92 & 28,300 & 28,100 & 28,100 \\
\hline 11.93 & 28,300 & 28,100 & 28,100 \\
\hline
\end{tabular}

\begin{tabular}{rrrr}
\hline & \multicolumn{3}{c}{ Flow (cfs) } \\
\cline { 2 - 4 } Stage (ft) & 2005 & 2012 & 2014 \\
\hline 11.94 & 28,400 & 28,200 & 28,200 \\
11.95 & 28,400 & 28,200 & 28,200 \\
11.96 & 28,400 & 28,200 & 28,200 \\
11.97 & 28,500 & 28,300 & 28,300 \\
11.98 & 28,500 & 28,300 & 28,300 \\
11.99 & 28,600 & 28,400 & 28,300 \\
12.00 & 28,600 & 28,400 & 28,400 \\
12.01 & 28,600 & 28,400 & 28,400 \\
12.02 & 28,700 & 28,500 & 28,500 \\
12.03 & 28,700 & 28,500 & 28,500 \\
12.04 & 28,800 & 28,600 & 28,500 \\
12.05 & 28,800 & 28,600 & 28,600 \\
12.06 & 28,800 & 28,600 & 28,600 \\
12.07 & 28,900 & 28,700 & 28,600 \\
12.08 & 28,900 & 28,700 & 28,700 \\
12.09 & 29,000 & 28,800 & 28,700 \\
12.10 & 29,000 & 28,800 & 28,700 \\
12.11 & 29,000 & 28,800 & 28,800 \\
12.12 & 29,100 & 28,900 & 28,800 \\
12.13 & 29,100 & 28,900 & 28,900 \\
12.14 & 29,200 & 29,000 & 28,900 \\
12.15 & 29,200 & 29,000 & 28,900 \\
12.16 & 29,200 & 29,000 & 29,000 \\
12.17 & 29,300 & 29,100 & 29,000 \\
12.18 & 29,300 & 29,100 & 29,000 \\
12.19 & 29,400 & 29,200 & 29,100 \\
12.20 & 29,400 & 29,200 & 29,100 \\
12.21 & 29,400 & 29,200 & 29,100
\end{tabular}


TABLE A-2 USGS Stage-Flow Table for the Ouray Gage (USGS 9272400) in 2012 and 2014

\begin{tabular}{cr}
\hline Stage & Flow \\
(ft) & (cfs) \\
\hline 14.94 & 930 \\
14.95 & 940 \\
14.96 & 951 \\
14.97 & 961 \\
14.98 & 972 \\
14.99 & 982 \\
15.00 & 992 \\
15.01 & 1,000 \\
15.02 & 1,010 \\
15.03 & 1,020 \\
15.04 & 1,030 \\
15.05 & 1,050 \\
15.06 & 1,060 \\
15.07 & 1,070 \\
15.08 & 1,080 \\
15.09 & 1,090 \\
15.10 & 1,100 \\
15.11 & 1,110 \\
15.12 & 1,120 \\
15.13 & 1,130 \\
15.14 & 1,140 \\
15.15 & 1,150 \\
15.16 & 1,160 \\
15.17 & 1,180 \\
15.18 & 1,190 \\
15.19 & 1,200 \\
15.20 & 1,210 \\
15.21 & 1,220 \\
15.22 & 1,230 \\
15.23 & 1,240 \\
15.24 & 1,250 \\
15.25 & 1,270 \\
15.26 & 1,280 \\
15.27 & 1,290 \\
15.28 & 1,300 \\
15.29 & 1,310 \\
15.30 & 1,320 \\
15.31 & 1,330 \\
15.32 & 1,350 \\
15.33 & 1,360
\end{tabular}

\begin{tabular}{cr}
\hline Stage & Flow \\
(ft) & (cfs) \\
\hline 15.34 & 1,370 \\
15.35 & 1,380 \\
15.36 & 1,390 \\
15.37 & 1,400 \\
15.38 & 1,420 \\
15.39 & 1,430 \\
15.40 & 1,440 \\
15.41 & 1,450 \\
15.42 & 1,460 \\
15.43 & 1,470 \\
15.44 & 1,490 \\
15.45 & 1,500 \\
15.46 & 1,510 \\
15.47 & 1,520 \\
15.48 & 1,530 \\
15.49 & 1,550 \\
15.50 & 1,560 \\
15.51 & 1,570 \\
15.52 & 1,580 \\
15.53 & 1,590 \\
15.54 & 1,610 \\
15.55 & 1,620 \\
15.56 & 1,630 \\
15.57 & 1,640 \\
15.58 & 1,660 \\
15.59 & 1,670 \\
15.60 & 1,680 \\
15.61 & 1,690 \\
15.62 & 1,710 \\
15.63 & 1,720 \\
15.64 & 1,730 \\
15.65 & 1,740 \\
15.66 & 1,760 \\
15.67 & 1,770 \\
15.68 & 1,780 \\
15.69 & 1,790 \\
15.70 & 1,810 \\
15.71 & 1,820 \\
15.72 & 1,830 \\
15.73 & 1,840
\end{tabular}

\begin{tabular}{cr} 
Stage & Flow \\
(ft) & (cfs) \\
\hline 15.74 & 1,860 \\
15.75 & 1,870 \\
15.76 & 1,880 \\
15.77 & 1,900 \\
15.78 & 1,910 \\
15.79 & 1,920 \\
15.80 & 1,930 \\
15.81 & 1,950 \\
15.82 & 1,960 \\
15.83 & 1,970 \\
15.84 & 1,990 \\
15.85 & 2,000 \\
15.86 & 2,010 \\
15.87 & 2,030 \\
15.88 & 2,040 \\
15.89 & 2,050 \\
15.90 & 2,060 \\
15.91 & 2,080 \\
15.92 & 2,090 \\
15.93 & 2,100 \\
15.94 & 2,120 \\
15.95 & 2,130 \\
15.96 & 2,140 \\
15.97 & 2,160 \\
15.98 & 2,170 \\
15.99 & 2,180 \\
16.00 & 2,200 \\
16.01 & 2,210 \\
16.02 & 2,220 \\
16.03 & 2,240 \\
16.04 & 2,250 \\
16.05 & 2,270 \\
16.06 & 2,280 \\
16.07 & 2,290 \\
16.08 & 2,310 \\
16.09 & 2,320 \\
16.10 & 2,330 \\
16.11 & 2,350 \\
16.12 & 2,360 \\
& 2,370 \\
& \\
16.13 &
\end{tabular}




\begin{tabular}{|c|c|}
\hline $\begin{array}{l}\text { Stage } \\
\text { (ft) }\end{array}$ & $\begin{array}{l}\text { Flow } \\
\text { (cfs) }\end{array}$ \\
\hline 16.14 & 2,390 \\
\hline 16.15 & 2,400 \\
\hline 16.16 & 2,420 \\
\hline 16.17 & 2,430 \\
\hline 16.18 & 2,440 \\
\hline 16.19 & 2,460 \\
\hline 16.20 & 2,470 \\
\hline 16.21 & 2,490 \\
\hline 16.22 & 2,500 \\
\hline 16.23 & 2,510 \\
\hline 16.24 & 2,530 \\
\hline 16.25 & 2,540 \\
\hline 16.26 & 2,560 \\
\hline 16.27 & 2,570 \\
\hline 16.28 & 2,580 \\
\hline 16.29 & 2,600 \\
\hline 16.30 & 2,610 \\
\hline 16.31 & 2,630 \\
\hline 16.32 & 2,640 \\
\hline 16.33 & 2,660 \\
\hline 16.34 & 2,670 \\
\hline 16.35 & 2,680 \\
\hline 16.36 & 2,700 \\
\hline 16.37 & 2,710 \\
\hline 16.38 & 2,730 \\
\hline 16.39 & 2,740 \\
\hline 16.40 & 2,760 \\
\hline 16.41 & 2,770 \\
\hline 16.42 & 2,780 \\
\hline 16.43 & 2,800 \\
\hline 16.44 & 2,810 \\
\hline 16.45 & 2,830 \\
\hline 16.46 & 2,840 \\
\hline 16.47 & 2,860 \\
\hline 16.48 & 2,870 \\
\hline 16.49 & 2,890 \\
\hline 16.50 & 2,900 \\
\hline 16.51 & 2,920 \\
\hline 16.52 & 2,930 \\
\hline 16.53 & 2,950 \\
\hline 16.54 & 2,960 \\
\hline 16.55 & 2,970 \\
\hline
\end{tabular}

\begin{tabular}{cr}
\hline Stage & Flow \\
(ft) & (cfs) \\
\hline 16.56 & 2,990 \\
16.57 & 3,000 \\
16.58 & 3,020 \\
16.59 & 3,030 \\
16.60 & 3,050 \\
16.61 & 3,060 \\
16.62 & 3,080 \\
16.63 & 3,090 \\
16.64 & 3,110 \\
16.65 & 3,120 \\
16.66 & 3,140 \\
16.67 & 3,150 \\
16.68 & 3,170 \\
16.69 & 3,180 \\
16.70 & 3,200 \\
16.71 & 3,210 \\
16.72 & 3,230 \\
16.73 & 3,240 \\
16.74 & 3,260 \\
16.75 & 3,270 \\
16.76 & 3,290 \\
16.77 & 3,310 \\
16.78 & 3,320 \\
16.79 & 3,340 \\
16.80 & 3,350 \\
16.81 & 3,370 \\
16.82 & 3,380 \\
16.93 & 3,400 \\
16.95 & 3,980 \\
16.97 & 3,600 \\
16.84 & 3,410 \\
16.85 & 3,430 \\
16.86 & 3,440 \\
16.87 & 3,460 \\
16.88 & 3,470 \\
16.89 & 3,490 \\
& 3,510 \\
169 & 3,520 \\
1640 \\
169
\end{tabular}

\begin{tabular}{|c|c|}
\hline $\begin{array}{l}\text { Stage } \\
(\mathrm{ft})\end{array}$ & $\begin{array}{r}\text { Flow } \\
(\mathrm{cfs})\end{array}$ \\
\hline 16.98 & 3,630 \\
\hline 16.99 & 3,650 \\
\hline 17.00 & 3,660 \\
\hline 17.01 & 3,680 \\
\hline 17.02 & 3,690 \\
\hline 17.03 & 3,710 \\
\hline 17.04 & 3,730 \\
\hline 17.05 & 3,740 \\
\hline 17.06 & 3,760 \\
\hline 17.07 & 3,770 \\
\hline 17.08 & 3,790 \\
\hline 17.09 & 3,810 \\
\hline 17.10 & 3,820 \\
\hline 17.11 & 3,840 \\
\hline 17.12 & 3,850 \\
\hline 17.13 & 3,870 \\
\hline 17.14 & 3,890 \\
\hline 17.15 & 3,900 \\
\hline 17.16 & 3,920 \\
\hline 17.17 & 3,930 \\
\hline 17.18 & 3,950 \\
\hline 17.19 & 3,970 \\
\hline 17.20 & 3,980 \\
\hline 17.21 & 4,000 \\
\hline 17.22 & 4,010 \\
\hline 17.23 & 4,030 \\
\hline 17.24 & 4,050 \\
\hline 17.25 & 4,060 \\
\hline 17.26 & 4,080 \\
\hline 17.27 & 4,100 \\
\hline 17.28 & 4,110 \\
\hline 17.29 & 4,130 \\
\hline 17.30 & 4,140 \\
\hline 17.31 & 4,160 \\
\hline 17.32 & 4,180 \\
\hline 17.33 & 4,190 \\
\hline 17.34 & 4,210 \\
\hline 17.35 & 4,230 \\
\hline 17.36 & 4,240 \\
\hline 17.37 & 4,260 \\
\hline 17.38 & 4,280 \\
\hline 17.39 & 4,290 \\
\hline
\end{tabular}




\begin{tabular}{|c|c|}
\hline $\begin{array}{l}\text { Stage } \\
(\mathrm{ft})\end{array}$ & $\begin{array}{r}\text { Flow } \\
(\mathrm{cfs})\end{array}$ \\
\hline 17.40 & 4,310 \\
\hline 17.41 & 4,330 \\
\hline 17.42 & 4,340 \\
\hline 17.43 & 4,360 \\
\hline 17.44 & 4,380 \\
\hline 17.45 & 4,390 \\
\hline 17.46 & 4,410 \\
\hline 17.47 & 4,430 \\
\hline 17.48 & 4,440 \\
\hline 17.49 & 4,460 \\
\hline 17.50 & 4,480 \\
\hline 17.51 & 4,490 \\
\hline 17.52 & 4,510 \\
\hline 17.53 & 4,530 \\
\hline 17.54 & 4,540 \\
\hline 17.55 & 4,560 \\
\hline 17.56 & 4,580 \\
\hline 17.57 & 4,590 \\
\hline 17.58 & 4,610 \\
\hline 17.59 & 4,630 \\
\hline 17.60 & 4,640 \\
\hline 17.61 & 4,660 \\
\hline 17.62 & 4,680 \\
\hline 17.63 & 4,700 \\
\hline 17.64 & 4,710 \\
\hline 17.65 & 4,730 \\
\hline 17.66 & 4,750 \\
\hline 17.67 & 4,760 \\
\hline 17.68 & 4,780 \\
\hline 17.69 & 4,800 \\
\hline 17.70 & 4,820 \\
\hline 17.71 & 4,830 \\
\hline 17.72 & 4,850 \\
\hline 17.73 & 4,870 \\
\hline 17.74 & 4,880 \\
\hline 17.75 & 4,900 \\
\hline 17.76 & 4,920 \\
\hline 17.77 & 4,940 \\
\hline 17.78 & 4,950 \\
\hline 17.79 & 4,970 \\
\hline 17.80 & 4,990 \\
\hline 17.81 & 5,010 \\
\hline
\end{tabular}

\begin{tabular}{|c|c|c|c|}
\hline $\begin{array}{l}\text { Stage } \\
(\mathrm{ft})\end{array}$ & $\begin{array}{r}\text { Flow } \\
(\mathrm{cfs})\end{array}$ & $\begin{array}{l}\text { Stage } \\
(\mathrm{ft})\end{array}$ & $\begin{array}{r}\text { Flow } \\
\text { (cfs) }\end{array}$ \\
\hline 17.82 & 5,020 & 18.24 & 5,770 \\
\hline 17.83 & 5,040 & 18.25 & 5,790 \\
\hline 17.84 & 5,060 & 18.26 & 5,810 \\
\hline 17.85 & 5,080 & 18.27 & 5,820 \\
\hline 17.86 & 5,090 & 18.28 & 5,840 \\
\hline 17.87 & 5,110 & 18.29 & 5,860 \\
\hline 17.88 & 5,130 & 18.30 & 5,880 \\
\hline 17.89 & 5,150 & 18.31 & 5,900 \\
\hline 17.90 & 5,160 & 18.32 & 5,920 \\
\hline 17.91 & 5,180 & 18.33 & 5,930 \\
\hline 17.92 & 5,200 & 18.34 & 5,950 \\
\hline 17.93 & 5,220 & 18.35 & 5,970 \\
\hline 17.94 & 5,230 & 18.36 & 5,990 \\
\hline 17.95 & 5,250 & 18.37 & 6,010 \\
\hline 17.96 & 5,270 & 18.38 & 6,030 \\
\hline 17.97 & 5,290 & 18.39 & 6,040 \\
\hline 17.98 & 5,300 & 18.40 & 6,060 \\
\hline 17.99 & 5,320 & 18.41 & 6,080 \\
\hline 18.00 & 5,340 & 18.42 & 6,100 \\
\hline 18.01 & 5,360 & 18.43 & 6,120 \\
\hline 18.02 & 5,370 & 18.44 & 6,140 \\
\hline 18.03 & 5,390 & 18.45 & 6,150 \\
\hline 18.04 & 5,410 & 18.46 & 6,170 \\
\hline 18.05 & 5,430 & 18.47 & 6,190 \\
\hline 18.06 & 5,450 & 18.48 & 6,210 \\
\hline 18.07 & 5,460 & 18.49 & 6,230 \\
\hline 18.08 & 5,480 & 18.50 & 6,250 \\
\hline 18.09 & 5,500 & 18.51 & 6,270 \\
\hline 18.10 & 5,520 & 18.52 & 6,280 \\
\hline 18.11 & 5,540 & 18.53 & 6,300 \\
\hline 18.12 & 5,550 & 18.54 & 6,320 \\
\hline 18.13 & 5,570 & 18.55 & 6,340 \\
\hline 18.14 & 5,590 & 18.56 & 6,360 \\
\hline 18.15 & 5,610 & 18.57 & 6,380 \\
\hline 18.16 & 5,620 & 18.58 & 6,400 \\
\hline 18.17 & 5,640 & 18.59 & 6,420 \\
\hline 18.18 & 5,660 & 18.60 & 6,430 \\
\hline 18.19 & 5,680 & 18.61 & 6,450 \\
\hline 18.20 & 5,700 & 18.62 & 6,470 \\
\hline 18.21 & 5,720 & 18.63 & 6,490 \\
\hline 18.22 & 5,730 & 18.64 & 6,510 \\
\hline 18.23 & 5,750 & 18.65 & 6,530 \\
\hline
\end{tabular}




\begin{tabular}{|c|c|}
\hline $\begin{array}{l}\text { Stage } \\
\text { (ft) }\end{array}$ & $\begin{array}{l}\text { Flow } \\
\text { (cfs) }\end{array}$ \\
\hline 18.66 & 6,550 \\
\hline 18.67 & 6,570 \\
\hline 18.68 & 6,590 \\
\hline 18.69 & 6,600 \\
\hline 18.70 & 6,620 \\
\hline 18.71 & 6,640 \\
\hline 18.72 & 6,660 \\
\hline 18.73 & 6,680 \\
\hline 18.74 & 6,700 \\
\hline 18.75 & 6,720 \\
\hline 18.76 & 6,740 \\
\hline 18.77 & 6,760 \\
\hline 18.78 & 6,780 \\
\hline 18.79 & 6,790 \\
\hline 18.80 & 6,810 \\
\hline 18.81 & 6,830 \\
\hline 18.82 & 6,850 \\
\hline 18.83 & 6,870 \\
\hline 18.84 & 6,890 \\
\hline 18.85 & 6,910 \\
\hline 18.86 & 6,930 \\
\hline 18.87 & 6,950 \\
\hline 18.88 & 6,970 \\
\hline 18.89 & 6,990 \\
\hline 18.90 & 7,010 \\
\hline 18.91 & 7,020 \\
\hline 18.92 & 7,040 \\
\hline 18.93 & 7,060 \\
\hline 18.94 & 7,080 \\
\hline 18.95 & 7,100 \\
\hline 18.96 & 7,120 \\
\hline 18.97 & 7,140 \\
\hline 18.98 & 7,160 \\
\hline 18.99 & 7,180 \\
\hline 19.00 & 7,200 \\
\hline 19.01 & 7,220 \\
\hline 19.02 & 7,240 \\
\hline 19.03 & 7,260 \\
\hline 19.04 & 7,280 \\
\hline 19.05 & 7,300 \\
\hline 19.06 & 7,320 \\
\hline 19.07 & 7,340 \\
\hline
\end{tabular}

\begin{tabular}{|c|c|c|c|}
\hline $\begin{array}{l}\text { Stage } \\
(\mathrm{ft})\end{array}$ & $\begin{array}{l}\text { Flow } \\
\text { (cfs) }\end{array}$ & $\begin{array}{l}\text { Stage } \\
(\mathrm{ft})\end{array}$ & $\begin{array}{r}\text { Flow } \\
\text { (cfs) }\end{array}$ \\
\hline 19.08 & 7,360 & 19.50 & 8,190 \\
\hline 19.09 & 7,370 & 19.51 & 8,210 \\
\hline 19.10 & 7,390 & 19.52 & 8,230 \\
\hline 19.11 & 7,410 & 19.53 & 8,250 \\
\hline 19.12 & 7,430 & 19.54 & 8,270 \\
\hline 19.13 & 7,450 & 19.55 & 8,290 \\
\hline 19.14 & 7,470 & 19.56 & 8,310 \\
\hline 19.15 & 7,490 & 19.57 & 8,330 \\
\hline 19.16 & 7,510 & 19.58 & 8,350 \\
\hline 19.17 & 7,530 & 19.59 & 8,370 \\
\hline 19.18 & 7,550 & 19.60 & 8,390 \\
\hline 19.19 & 7,570 & 19.61 & 8,410 \\
\hline 19.20 & 7,590 & 19.62 & 8,440 \\
\hline 19.21 & 7,610 & 19.63 & 8,460 \\
\hline 19.22 & 7,630 & 19.64 & 8,480 \\
\hline 19.23 & 7,650 & 19.65 & 8,500 \\
\hline 19.24 & 7,670 & 19.66 & 8,520 \\
\hline 19.25 & 7,690 & 19.67 & 8,540 \\
\hline 19.26 & 7,710 & 19.68 & 8,560 \\
\hline 19.27 & 7,730 & 19.69 & 8,580 \\
\hline 19.28 & 7,750 & 19.70 & 8,600 \\
\hline 19.29 & 7,770 & 19.71 & 8,620 \\
\hline 19.30 & 7,790 & 19.72 & 8,640 \\
\hline 19.31 & 7,810 & 19.73 & 8,660 \\
\hline 19.32 & 7,830 & 19.74 & 8,680 \\
\hline 19.33 & 7,850 & 19.75 & 8,700 \\
\hline 19.34 & 7,870 & 19.76 & 8,720 \\
\hline 19.35 & 7,890 & 19.77 & 8,740 \\
\hline 19.36 & 7,910 & 19.78 & 8,760 \\
\hline 19.37 & 7,930 & 19.79 & 8,780 \\
\hline 19.38 & 7,950 & 19.80 & 8,810 \\
\hline 19.39 & 7,970 & 19.81 & 8,830 \\
\hline 19.40 & 7,990 & 19.82 & 8,850 \\
\hline 19.41 & 8,010 & 19.83 & 8,870 \\
\hline 19.42 & 8,030 & 19.84 & 8,890 \\
\hline 19.43 & 8,050 & 19.85 & 8,910 \\
\hline 19.44 & 8,070 & 19.86 & 8,930 \\
\hline 19.45 & 8,090 & 19.87 & 8,950 \\
\hline 19.46 & 8,110 & 19.88 & 8,970 \\
\hline 19.47 & 8,130 & 19.89 & 8,990 \\
\hline 19.48 & 8,150 & 19.90 & 9,010 \\
\hline 19.49 & 8,170 & 19.91 & 9,030 \\
\hline
\end{tabular}




\begin{tabular}{|c|c|}
\hline $\begin{array}{l}\text { Stage } \\
\text { (ft) }\end{array}$ & $\begin{array}{r}\text { Flow } \\
\text { (cfs) }\end{array}$ \\
\hline 19.92 & 9,060 \\
\hline 19.93 & 9,080 \\
\hline 19.94 & 9,100 \\
\hline 19.95 & 9,120 \\
\hline 19.96 & 9,140 \\
\hline 19.97 & 9,160 \\
\hline 19.98 & 9,180 \\
\hline 19.99 & 9,200 \\
\hline 20.00 & 9,220 \\
\hline 20.01 & 9,240 \\
\hline 20.02 & 9,260 \\
\hline 20.03 & 9,290 \\
\hline 20.04 & 9,310 \\
\hline 20.05 & 9,330 \\
\hline 20.06 & 9,350 \\
\hline 20.07 & 9,370 \\
\hline 20.08 & 9,390 \\
\hline 20.09 & 9,410 \\
\hline 20.10 & 9,430 \\
\hline 20.11 & 9,450 \\
\hline 20.12 & 9,480 \\
\hline 20.13 & 9,500 \\
\hline 20.14 & 9,520 \\
\hline 20.15 & 9,540 \\
\hline 20.16 & 9,560 \\
\hline 20.17 & 9,580 \\
\hline 20.18 & 9,600 \\
\hline 20.19 & 9,620 \\
\hline 20.20 & 9,650 \\
\hline 20.21 & 9,670 \\
\hline 20.22 & 9,690 \\
\hline 20.23 & 9,710 \\
\hline 20.24 & 9,730 \\
\hline 20.25 & 9,750 \\
\hline 20.26 & 9,770 \\
\hline 20.27 & 9,800 \\
\hline 20.28 & 9,820 \\
\hline 20.29 & 9,840 \\
\hline 20.30 & 9,860 \\
\hline 20.31 & 9,880 \\
\hline 20.32 & 9,900 \\
\hline 20.33 & 9,920 \\
\hline
\end{tabular}

\begin{tabular}{cr}
\hline Stage & Flow \\
(ft) & (cfs) \\
\hline 20.34 & 9,950 \\
20.35 & 9,970 \\
20.36 & 9,990 \\
20.37 & 10,000 \\
20.38 & 10,000 \\
20.39 & 10,100 \\
20.40 & 10,100 \\
20.41 & 10,100 \\
20.42 & 10,100 \\
20.43 & 10,100 \\
20.44 & 10,200 \\
20.45 & 10,200 \\
20.46 & 10,200 \\
20.47 & 10,200 \\
20.48 & 10,200 \\
20.49 & 10,300 \\
20.50 & 10,300 \\
20.51 & 10,300 \\
20.52 & 10,300 \\
20.53 & 10,400 \\
20.54 & 10,400 \\
20.55 & 10,400 \\
20.56 & 10,400 \\
20.57 & 10,400 \\
20.58 & 10,500 \\
20.59 & 10,500 \\
20.73 & 10,800 \\
20.74 & 10,800 \\
20.75 & 10,800 \\
20.61 & 10,500 \\
20.62 & 10,600 \\
20.63 & 10,600 \\
20.64 & 10,600 \\
20.65 & 10,600 \\
20.66 & 10,600 \\
20.67 & 10,700 \\
& 10,700 \\
20.68 & 10,700 \\
20,700 \\
2000 \\
20
\end{tabular}

\begin{tabular}{|c|c|}
\hline $\begin{array}{l}\text { Stage } \\
\text { (ft) }\end{array}$ & $\begin{array}{l}\text { Flow } \\
\text { (cfs) }\end{array}$ \\
\hline 20.76 & 10,900 \\
\hline 20.77 & 10,900 \\
\hline 20.78 & 10,900 \\
\hline 20.79 & 10,900 \\
\hline 20.80 & 10,900 \\
\hline 20.81 & 11,000 \\
\hline 20.82 & 11,000 \\
\hline 20.83 & 11,000 \\
\hline 20.84 & 11,000 \\
\hline 20.85 & 11,100 \\
\hline 20.86 & 11,100 \\
\hline 20.87 & 11,100 \\
\hline 20.88 & 11,100 \\
\hline 20.89 & 11,100 \\
\hline 20.90 & 11,200 \\
\hline 20.91 & 11,200 \\
\hline 20.92 & 11,200 \\
\hline 20.93 & 11,200 \\
\hline 20.94 & 11,300 \\
\hline 20.95 & 11,300 \\
\hline 20.96 & 11,300 \\
\hline 20.97 & 11,300 \\
\hline 20.98 & 11,400 \\
\hline 20.99 & 11,400 \\
\hline 21.00 & 11,400 \\
\hline 21.01 & 11,400 \\
\hline 21.02 & 11,400 \\
\hline 21.03 & 11,500 \\
\hline 21.04 & 11,500 \\
\hline 21.05 & 11,500 \\
\hline 21.06 & 11,500 \\
\hline 21.07 & 11,600 \\
\hline 21.08 & 11,600 \\
\hline 21.09 & 11,600 \\
\hline 21.10 & 11,600 \\
\hline 21.11 & 11,600 \\
\hline 21.12 & 11,700 \\
\hline 21.13 & 11,700 \\
\hline 21.14 & 11,700 \\
\hline 21.15 & 11,700 \\
\hline 21.16 & 11,800 \\
\hline 21.17 & 11,800 \\
\hline
\end{tabular}




\begin{tabular}{|c|c|}
\hline $\begin{array}{l}\text { Stage } \\
\text { (ft) }\end{array}$ & $\begin{array}{l}\text { Flow } \\
\text { (cfs) }\end{array}$ \\
\hline 21.18 & 11,800 \\
\hline 21.19 & 11,800 \\
\hline 21.20 & 11,800 \\
\hline 21.21 & 11,900 \\
\hline 21.22 & 11,900 \\
\hline 21.23 & 11,900 \\
\hline 21.24 & 11,900 \\
\hline 21.25 & 12,000 \\
\hline 21.26 & 12,000 \\
\hline 21.27 & 12,000 \\
\hline 21.28 & 12,000 \\
\hline 21.29 & 12,100 \\
\hline 21.30 & 12,100 \\
\hline 21.31 & 12,100 \\
\hline 21.32 & 12,100 \\
\hline 21.33 & 12,100 \\
\hline 21.34 & 12,200 \\
\hline 21.35 & 12,200 \\
\hline 21.36 & 12,200 \\
\hline 21.37 & 12,200 \\
\hline 21.38 & 12,300 \\
\hline 21.39 & 12,300 \\
\hline 21.40 & 12,300 \\
\hline 21.41 & 12,300 \\
\hline 21.42 & 12,300 \\
\hline 21.43 & 12,400 \\
\hline 21.44 & 12,400 \\
\hline 21.45 & 12,400 \\
\hline 21.46 & 12,400 \\
\hline 21.47 & 12,500 \\
\hline 21.48 & 12,500 \\
\hline 21.49 & 12,500 \\
\hline 21.50 & 12,500 \\
\hline 21.51 & 12,600 \\
\hline 21.52 & 12,600 \\
\hline 21.53 & 12,600 \\
\hline 21.54 & 12,600 \\
\hline 21.55 & 12,600 \\
\hline 21.56 & 12,700 \\
\hline 21.57 & 12,700 \\
\hline 21.58 & 12,700 \\
\hline 21.59 & 12,700 \\
\hline
\end{tabular}

\begin{tabular}{|c|c|}
\hline $\begin{array}{l}\text { Stage } \\
(\mathrm{ft})\end{array}$ & $\begin{array}{r}\text { Flow } \\
\text { (cfs) }\end{array}$ \\
\hline 21.60 & 12,800 \\
\hline 21.61 & 12,800 \\
\hline 21.62 & 12,800 \\
\hline 21.63 & 12,800 \\
\hline 21.64 & 12,900 \\
\hline 21.65 & 12,900 \\
\hline 21.66 & 12,900 \\
\hline 21.67 & 12,900 \\
\hline 21.68 & 13,000 \\
\hline 21.69 & 13,000 \\
\hline 21.70 & 13,000 \\
\hline 21.71 & 13,000 \\
\hline 21.72 & 13,000 \\
\hline 21.73 & 13,100 \\
\hline 21.74 & 13,100 \\
\hline 21.75 & 13,100 \\
\hline 21.76 & 13,100 \\
\hline 21.77 & 13,200 \\
\hline 21.78 & 13,200 \\
\hline 21.79 & 13,200 \\
\hline 21.80 & 13,200 \\
\hline 21.81 & 13,300 \\
\hline 21.82 & 13,300 \\
\hline 21.83 & 13,300 \\
\hline 21.84 & 13,300 \\
\hline 21.85 & 13,300 \\
\hline 21.86 & 13,400 \\
\hline 21.87 & 13,400 \\
\hline 21.88 & 13,400 \\
\hline 21.89 & 13,400 \\
\hline 21.90 & 13,500 \\
\hline 21.91 & 13,500 \\
\hline 21.92 & 13,500 \\
\hline 21.93 & 13,500 \\
\hline 21.94 & 13,600 \\
\hline 21.95 & 13,600 \\
\hline 21.96 & 13,600 \\
\hline 21.97 & 13,600 \\
\hline 21.98 & 13,700 \\
\hline 21.99 & 13,700 \\
\hline 22.00 & 13,700 \\
\hline 22.01 & 13,700 \\
\hline
\end{tabular}

\begin{tabular}{|c|c|}
\hline $\begin{array}{l}\text { Stage } \\
(\mathrm{ft})\end{array}$ & $\begin{array}{r}\text { Flow } \\
(\mathrm{cfs})\end{array}$ \\
\hline 22.02 & 13,800 \\
\hline 22.03 & 13,800 \\
\hline 22.04 & 13,800 \\
\hline 22.05 & 13,800 \\
\hline 22.06 & 13,800 \\
\hline 22.07 & 13,900 \\
\hline 22.08 & 13,900 \\
\hline 22.09 & 13,900 \\
\hline 22.10 & 13,900 \\
\hline 22.11 & 14,000 \\
\hline 22.12 & 14,000 \\
\hline 22.13 & 14,000 \\
\hline 22.14 & 14,000 \\
\hline 22.15 & 14,100 \\
\hline 22.16 & 14,100 \\
\hline 22.17 & 14,100 \\
\hline 22.18 & 14,100 \\
\hline 22.19 & 14,200 \\
\hline 22.20 & 14,200 \\
\hline 22.21 & 14,200 \\
\hline 22.22 & 14,200 \\
\hline 22.23 & 14,300 \\
\hline 22.24 & 14,300 \\
\hline 22.25 & 14,300 \\
\hline 22.26 & 14,300 \\
\hline 22.27 & 14,400 \\
\hline 22.28 & 14,400 \\
\hline 22.29 & 14,400 \\
\hline 22.30 & 14,400 \\
\hline 22.31 & 14,400 \\
\hline 22.32 & 14,500 \\
\hline 22.33 & 14,500 \\
\hline 22.34 & 14,500 \\
\hline 22.35 & 14,500 \\
\hline 22.36 & 14,600 \\
\hline 22.37 & 14,600 \\
\hline 22.38 & 14,600 \\
\hline 22.39 & 14,600 \\
\hline 22.40 & 14,700 \\
\hline 22.41 & 14,700 \\
\hline 22.42 & 14,700 \\
\hline 22.43 & 14,700 \\
\hline
\end{tabular}




\begin{tabular}{|c|c|}
\hline $\begin{array}{l}\text { Stage } \\
\text { (ft) }\end{array}$ & $\begin{array}{l}\text { Flow } \\
\text { (cfs) }\end{array}$ \\
\hline 22.44 & 14,800 \\
\hline 22.45 & 14,800 \\
\hline 22.46 & 14,800 \\
\hline 22.47 & 14,800 \\
\hline 22.48 & 14,900 \\
\hline 22.49 & 14,900 \\
\hline 22.50 & 14,900 \\
\hline 22.51 & 14,900 \\
\hline 22.52 & 15,000 \\
\hline 22.53 & 15,000 \\
\hline 22.54 & 15,000 \\
\hline 22.55 & 15,000 \\
\hline 22.56 & 15,100 \\
\hline 22.57 & 15,100 \\
\hline 22.58 & 15,100 \\
\hline 22.59 & 15,100 \\
\hline 22.60 & 15,200 \\
\hline 22.61 & 15,200 \\
\hline 22.62 & 15,200 \\
\hline 22.63 & 15,200 \\
\hline 22.64 & 15,300 \\
\hline 22.65 & 15,300 \\
\hline 22.66 & 15,300 \\
\hline 22.67 & 15,300 \\
\hline 22.68 & 15,300 \\
\hline 22.69 & 15,400 \\
\hline 22.70 & 15,400 \\
\hline 22.71 & 15,400 \\
\hline 22.72 & 15,400 \\
\hline 22.73 & 15,500 \\
\hline 22.74 & 15,500 \\
\hline 22.75 & 15,500 \\
\hline 22.76 & 15,500 \\
\hline 22.77 & 15,600 \\
\hline 22.78 & 15,600 \\
\hline 22.79 & 15,600 \\
\hline 22.80 & 15,600 \\
\hline 22.81 & 15,700 \\
\hline 22.82 & 15,700 \\
\hline 22.83 & 15,700 \\
\hline 22.84 & 15,700 \\
\hline 22.85 & 15,800 \\
\hline
\end{tabular}

\begin{tabular}{|c|c|}
\hline $\begin{array}{l}\text { Stage } \\
(\mathrm{ft})\end{array}$ & $\begin{array}{r}\text { Flow } \\
\text { (cfs) }\end{array}$ \\
\hline 22.86 & 15,800 \\
\hline 22.87 & 15,800 \\
\hline 22.88 & 15,800 \\
\hline 22.89 & 15,900 \\
\hline 22.90 & 15,900 \\
\hline 22.91 & 15,900 \\
\hline 22.92 & 15,900 \\
\hline 22.93 & 16,000 \\
\hline 22.94 & 16,000 \\
\hline 22.95 & 16,000 \\
\hline 22.96 & 16,000 \\
\hline 22.97 & 16,100 \\
\hline 22.98 & 16,100 \\
\hline 22.99 & 16,100 \\
\hline 23.00 & 16,100 \\
\hline 23.01 & 16,200 \\
\hline 23.02 & 16,200 \\
\hline 23.03 & 16,200 \\
\hline 23.04 & 16,200 \\
\hline 23.05 & 16,300 \\
\hline 23.06 & 16,300 \\
\hline 23.07 & 16,300 \\
\hline 23.08 & 16,300 \\
\hline 23.09 & 16,400 \\
\hline 23.10 & 16,400 \\
\hline 23.11 & 16,400 \\
\hline 23.12 & 16,400 \\
\hline 23.13 & 16,500 \\
\hline 23.14 & 16,500 \\
\hline 23.15 & 16,500 \\
\hline 23.16 & 16,500 \\
\hline 23.17 & 16,600 \\
\hline 23.18 & 16,600 \\
\hline 23.19 & 16,600 \\
\hline 23.20 & 16,600 \\
\hline 23.21 & 16,700 \\
\hline 23.22 & 16,700 \\
\hline 23.23 & 16,700 \\
\hline 23.24 & 16,700 \\
\hline 23.25 & 16,800 \\
\hline 23.26 & 16,800 \\
\hline 23.27 & 16,800 \\
\hline
\end{tabular}

\begin{tabular}{|c|c|}
\hline $\begin{array}{l}\text { Stage } \\
(\mathrm{ft})\end{array}$ & $\begin{array}{r}\text { Flow } \\
(\mathrm{cfs})\end{array}$ \\
\hline 23.28 & 16,800 \\
\hline 23.29 & 16,900 \\
\hline 23.30 & 16,900 \\
\hline 23.31 & 16,900 \\
\hline 23.32 & 16,900 \\
\hline 23.33 & 17,000 \\
\hline 23.34 & 17,000 \\
\hline 23.35 & 17,000 \\
\hline 23.36 & 17,000 \\
\hline 23.37 & 17,100 \\
\hline 23.38 & 17,100 \\
\hline 23.39 & 17,100 \\
\hline 23.40 & 17,200 \\
\hline 23.41 & 17,200 \\
\hline 23.42 & 17,200 \\
\hline 23.43 & 17,200 \\
\hline 23.44 & 17,300 \\
\hline 23.45 & 17,300 \\
\hline 23.46 & 17,300 \\
\hline 23.47 & 17,300 \\
\hline 23.48 & 17,400 \\
\hline 23.49 & 17,400 \\
\hline 23.50 & 17,400 \\
\hline 23.51 & 17,400 \\
\hline 23.52 & 17,500 \\
\hline 23.53 & 17,500 \\
\hline 23.54 & 17,500 \\
\hline 23.55 & 17,500 \\
\hline 23.56 & 17,600 \\
\hline 23.57 & 17,600 \\
\hline 23.58 & 17,600 \\
\hline 23.59 & 17,600 \\
\hline 23.60 & 17,700 \\
\hline 23.61 & 17,700 \\
\hline 23.62 & 17,700 \\
\hline 23.63 & 17,700 \\
\hline 23.64 & 17,800 \\
\hline 23.65 & 17,800 \\
\hline 23.66 & 17,800 \\
\hline 23.67 & 17,800 \\
\hline 23.68 & 17,900 \\
\hline 23.69 & 17,900 \\
\hline
\end{tabular}




\begin{tabular}{|c|c|}
\hline $\begin{array}{l}\text { Stage } \\
\text { (ft) }\end{array}$ & $\begin{array}{l}\text { Flow } \\
\text { (cfs) }\end{array}$ \\
\hline 23.70 & 17,900 \\
\hline 23.71 & 17,900 \\
\hline 23.72 & 18,000 \\
\hline 23.73 & 18,000 \\
\hline 23.74 & 18,000 \\
\hline 23.75 & 18,000 \\
\hline 23.76 & 18,100 \\
\hline 23.77 & 18,100 \\
\hline 23.78 & 18,100 \\
\hline 23.79 & 18,200 \\
\hline 23.80 & 18,200 \\
\hline 23.81 & 18,200 \\
\hline 23.82 & 18,200 \\
\hline 23.83 & 18,300 \\
\hline 23.84 & 18,300 \\
\hline 23.85 & 18,300 \\
\hline 23.86 & 18,300 \\
\hline 23.87 & 18,400 \\
\hline 23.88 & 18,400 \\
\hline 23.89 & 18,400 \\
\hline 23.90 & 18,400 \\
\hline 23.91 & 18,500 \\
\hline 23.92 & 18,500 \\
\hline 23.93 & 18,500 \\
\hline 23.94 & 18,500 \\
\hline 23.95 & 18,600 \\
\hline 23.96 & 18,600 \\
\hline 23.97 & 18,600 \\
\hline 23.98 & 18,600 \\
\hline 23.99 & 18,700 \\
\hline 24.00 & 18,700 \\
\hline 24.01 & 18,700 \\
\hline 24.02 & 18,800 \\
\hline 24.03 & 18,800 \\
\hline 24.04 & 18,800 \\
\hline 24.05 & 18,800 \\
\hline 24.06 & 18,900 \\
\hline 24.07 & 18,900 \\
\hline 24.08 & 18,900 \\
\hline 24.09 & 18,900 \\
\hline 24.10 & 19,000 \\
\hline 24.11 & 19,000 \\
\hline
\end{tabular}

\begin{tabular}{|c|c|}
\hline $\begin{array}{l}\text { Stage } \\
(\mathrm{ft})\end{array}$ & $\begin{array}{r}\text { Flow } \\
\text { (cfs) }\end{array}$ \\
\hline 24.12 & 19,000 \\
\hline 24.13 & 19,000 \\
\hline 24.14 & 19,100 \\
\hline 24.15 & 19,100 \\
\hline 24.16 & 19,100 \\
\hline 24.17 & 19,100 \\
\hline 24.18 & 19,200 \\
\hline 24.19 & 19,200 \\
\hline 24.20 & 19,200 \\
\hline 24.21 & 19,300 \\
\hline 24.22 & 19,300 \\
\hline 24.23 & 19,300 \\
\hline 24.24 & 19,300 \\
\hline 24.25 & 19,400 \\
\hline 24.26 & 19,400 \\
\hline 24.27 & 19,400 \\
\hline 24.28 & 19,400 \\
\hline 24.29 & 19,500 \\
\hline 24.30 & 19,500 \\
\hline 24.31 & 19,500 \\
\hline 24.32 & 19,500 \\
\hline 24.33 & 19,600 \\
\hline 24.34 & 19,600 \\
\hline 24.35 & 19,600 \\
\hline 24.36 & 19,600 \\
\hline 24.37 & 19,700 \\
\hline 24.38 & 19,700 \\
\hline 24.39 & 19,700 \\
\hline 24.40 & 19,800 \\
\hline 24.41 & 19,800 \\
\hline 24.42 & 19,800 \\
\hline 24.43 & 19,800 \\
\hline 24.44 & 19,900 \\
\hline 24.45 & 19,900 \\
\hline 24.46 & 19,900 \\
\hline 24.47 & 19,900 \\
\hline 24.48 & 20,000 \\
\hline 24.49 & 20,000 \\
\hline 24.50 & 20,000 \\
\hline 24.51 & 20,000 \\
\hline 24.52 & 20,100 \\
\hline 24.53 & 20,100 \\
\hline
\end{tabular}

\begin{tabular}{|c|c|}
\hline $\begin{array}{l}\text { Stage } \\
\text { (ft) }\end{array}$ & $\begin{array}{r}\text { Flow } \\
\text { (cfs) }\end{array}$ \\
\hline 24.54 & 20,100 \\
\hline 24.55 & 20,200 \\
\hline 24.56 & 20,200 \\
\hline 24.57 & 20,200 \\
\hline 24.58 & 20,200 \\
\hline 24.59 & 20,300 \\
\hline 24.60 & 20,300 \\
\hline 24.61 & 20,300 \\
\hline 24.62 & 20,300 \\
\hline 24.63 & 20,400 \\
\hline 24.64 & 20,400 \\
\hline 24.65 & 20,400 \\
\hline 24.66 & 20,500 \\
\hline 24.67 & 20,500 \\
\hline 24.68 & 20,500 \\
\hline 24.69 & 20,500 \\
\hline 24.70 & 20,600 \\
\hline 24.71 & 20,600 \\
\hline 24.72 & 20,600 \\
\hline 24.73 & 20,600 \\
\hline 24.74 & 20,700 \\
\hline 24.75 & 20,700 \\
\hline 24.76 & 20,700 \\
\hline 24.77 & 20,700 \\
\hline 24.78 & 20,800 \\
\hline 24.79 & 20,800 \\
\hline 24.80 & 20,800 \\
\hline 24.81 & 20,900 \\
\hline 24.82 & 20,900 \\
\hline 24.83 & 20,900 \\
\hline 24.84 & 20,900 \\
\hline 24.85 & 21,000 \\
\hline 24.86 & 21,000 \\
\hline 24.87 & 21,000 \\
\hline 24.88 & 21,000 \\
\hline 24.89 & 21,100 \\
\hline 24.90 & 21,100 \\
\hline 24.91 & 21,100 \\
\hline 24.92 & 21,200 \\
\hline 24.93 & 21,200 \\
\hline 24.94 & 21,200 \\
\hline 24.95 & 21,200 \\
\hline
\end{tabular}




\begin{tabular}{cr}
\hline Stage & Flow \\
(ft) & (cfs) \\
\hline 24.96 & 21,300 \\
24.97 & 21,300 \\
24.98 & 21,300 \\
24.99 & 21,300 \\
25.00 & 21,400 \\
25.01 & 21,400 \\
25.02 & 21,400 \\
25.03 & 21,500 \\
25.04 & 21,500 \\
25.05 & 21,500 \\
25.06 & 21,500 \\
25.07 & 21,600 \\
25.08 & 21,600 \\
25.09 & 21,600 \\
25.10 & 21,600 \\
25.11 & 21,700 \\
25.12 & 21,700 \\
25.13 & 21,700 \\
25.14 & 21,800 \\
25.15 & 21,800 \\
25.16 & 21,800 \\
25.17 & 21,800 \\
25.18 & 21,900 \\
25.19 & 21,900 \\
25.20 & 21,900 \\
25.35 & 22,300 \\
25.21 & 21,900 \\
25.22 & 22,000 \\
25.23 & 22,000 \\
25.24 & 22,000 \\
25.33 & 225 \\
25.26 & 22,100 \\
25.27 & 22,100 \\
25.28 & 22,100 \\
25.29 & 22,200 \\
25.30 & 22,200 \\
& \\
25.300 \\
253
\end{tabular}

\begin{tabular}{|c|c|}
\hline $\begin{array}{l}\text { Stage } \\
(\mathrm{ft})\end{array}$ & $\begin{array}{r}\text { Flow } \\
\text { (cfs) }\end{array}$ \\
\hline 25.38 & 22,400 \\
\hline 25.39 & 22,400 \\
\hline 25.40 & 22,500 \\
\hline 25.41 & 22,500 \\
\hline 25.42 & 22,500 \\
\hline 25.43 & 22,600 \\
\hline 25.44 & 22,600 \\
\hline 25.45 & 22,600 \\
\hline 25.46 & 22,600 \\
\hline 25.47 & 22,700 \\
\hline 25.48 & 22,700 \\
\hline 25.49 & 22,700 \\
\hline 25.50 & 22,700 \\
\hline 25.51 & 22,800 \\
\hline 25.52 & 22,800 \\
\hline 25.53 & 22,800 \\
\hline 25.54 & 22,900 \\
\hline 25.55 & 22,900 \\
\hline 25.56 & 22,900 \\
\hline 25.57 & 22,900 \\
\hline 25.58 & 23,000 \\
\hline 25.59 & 23,000 \\
\hline 25.60 & 23,000 \\
\hline 25.61 & 23,100 \\
\hline 25.62 & 23,100 \\
\hline 25.63 & 23,100 \\
\hline 25.64 & 23,100 \\
\hline 25.65 & 23,200 \\
\hline 25.66 & 23,200 \\
\hline 25.67 & 23,200 \\
\hline 25.68 & 23,300 \\
\hline 25.69 & 23,300 \\
\hline 25.70 & 23,300 \\
\hline 25.71 & 23,400 \\
\hline 25.72 & 23,400 \\
\hline 25.73 & 23,400 \\
\hline 25.74 & 23,400 \\
\hline 25.75 & 23,500 \\
\hline 25.76 & 23,500 \\
\hline 25.77 & 23,500 \\
\hline 25.78 & 23,600 \\
\hline 25.79 & 23,600 \\
\hline
\end{tabular}

\begin{tabular}{|c|c|}
\hline $\begin{array}{l}\text { Stage } \\
\text { (ft) }\end{array}$ & $\begin{array}{r}\text { Flow } \\
\text { (cfs) }\end{array}$ \\
\hline 25.80 & 23,600 \\
\hline 25.81 & 23,700 \\
\hline 25.82 & 23,700 \\
\hline 25.83 & 23,700 \\
\hline 25.84 & 23,800 \\
\hline 25.85 & 23,800 \\
\hline 25.86 & 23,800 \\
\hline 25.87 & 23,900 \\
\hline 25.88 & 23,900 \\
\hline 25.89 & 23,900 \\
\hline 25.90 & 24,000 \\
\hline 25.91 & 24,000 \\
\hline 25.92 & 24,000 \\
\hline 25.93 & 24,100 \\
\hline 25.94 & 24,100 \\
\hline 25.95 & 24,100 \\
\hline 25.96 & 24,200 \\
\hline 25.97 & 24,200 \\
\hline 25.98 & 24,200 \\
\hline 25.99 & 24,200 \\
\hline 26.00 & 24,300 \\
\hline 26.01 & 24,300 \\
\hline 26.02 & 24,300 \\
\hline 26.03 & 24,400 \\
\hline 26.04 & 24,400 \\
\hline 26.05 & 24,400 \\
\hline 26.06 & 24,500 \\
\hline 26.07 & 24,500 \\
\hline 26.08 & 24,500 \\
\hline 26.09 & 24,600 \\
\hline 26.10 & 24,600 \\
\hline 26.11 & 24,600 \\
\hline 26.12 & 24,700 \\
\hline 26.13 & 24,700 \\
\hline 26.14 & 24,700 \\
\hline 26.15 & 24,800 \\
\hline 26.16 & 24,800 \\
\hline 26.17 & 24,800 \\
\hline 26.18 & 24,900 \\
\hline 26.19 & 24,900 \\
\hline 26.20 & 24,900 \\
\hline 26.21 & 25,000 \\
\hline
\end{tabular}




\begin{tabular}{cr}
\hline $\begin{array}{l}\text { Stage } \\
\text { (ft) }\end{array}$ & $\begin{array}{r}\text { Flow } \\
\text { (cfs) }\end{array}$ \\
\hline 26.22 & 25,000 \\
26.23 & 25,000 \\
26.24 & 25,100 \\
26.25 & 25,100 \\
26.26 & 25,100 \\
26.27 & 25,200 \\
26.28 & 25,200 \\
26.29 & 25,200 \\
26.30 & 25,300 \\
26.31 & 25,300 \\
26.32 & 25,300 \\
26.33 & 25,300 \\
26.34 & 25,400 \\
26.35 & 25,400 \\
26.36 & 25,400 \\
26.37 & 25,500 \\
26.38 & 25,500 \\
26.39 & 25,500 \\
26.40 & 25,600 \\
26.41 & 25,600 \\
26.42 & 25,600 \\
26.43 & 25,700 \\
26.44 & 25,700 \\
26.45 & 25,700 \\
26.46 & 25,800 \\
26.47 & 25,800 \\
26.48 & 25,800 \\
26.49 & 25,800 \\
26.50 & 25,900 \\
26.51 & 25,900 \\
26.52 & 25,900 \\
26.53 & 26,000 \\
26.54 & 26,000 \\
26.55 & 26,000 \\
26.56 & 26,000 \\
26.57 & 26,100 \\
26.58 & 26,100 \\
& \\
\hline
\end{tabular}

\begin{tabular}{rr}
\hline Stage & Flow \\
(ft) & (cfs) \\
\hline 26.59 & 26,200 \\
26.60 & 26,200 \\
26.61 & 26,200 \\
26.62 & 26,300 \\
26.63 & 26,300 \\
26.64 & 26,400 \\
26.65 & 26,400 \\
26.66 & 26,500 \\
26.67 & 26,500 \\
26.68 & 26,600 \\
26.69 & 26,600 \\
26.70 & 26,600 \\
26.71 & 26,700 \\
26.72 & 26,700 \\
26.73 & 26,800 \\
26.74 & 26,800 \\
26.75 & 26,900 \\
26.76 & 26,900 \\
26.77 & 26,900 \\
26.78 & 27,000 \\
26.79 & 27,000 \\
26.80 & 27,100 \\
26.81 & 27,100 \\
26.82 & 27,200 \\
26.83 & 27,200 \\
26.84 & 27,300 \\
26.85 & 27,300 \\
26.86 & 27,300 \\
26.87 & 27,400 \\
26.88 & 27,400 \\
26.89 & 27,500 \\
26.90 & 27,500 \\
26.91 & 27,600 \\
26.92 & 27,600 \\
26.93 & 27,700 \\
26.94 & 27,700 \\
26.95 & 27,700
\end{tabular}

\begin{tabular}{cr}
\hline $\begin{array}{lr}\text { Stage } \\
\text { (ft) }\end{array}$ & $\begin{array}{r}\text { Flow } \\
\text { (cfs) }\end{array}$ \\
\hline 26.96 & 27,800 \\
26.97 & 27,800 \\
26.98 & 27,900 \\
26.99 & 27,900 \\
27.00 & 28,000 \\
27.01 & 28,000 \\
27.02 & 28,100 \\
27.03 & 28,100 \\
27.04 & 28,200 \\
27.05 & 28,200 \\
27.06 & 28,200 \\
27.07 & 28,300 \\
27.08 & 28,300 \\
27.09 & 28,400 \\
27.10 & 28,400 \\
27.11 & 28,500 \\
27.12 & 28,500 \\
27.13 & 28,600 \\
27.14 & 28,600 \\
27.15 & 28,700 \\
27.16 & 28,700 \\
27.17 & 28,700 \\
27.18 & 28,800 \\
27.19 & 28,800 \\
27.20 & 28,900 \\
27.21 & 28,900 \\
27.22 & 29,000 \\
27.23 & 29,000 \\
27.24 & 29,100 \\
27.25 & 29,100 \\
27.26 & 29,200 \\
27.27 & 29,200 \\
27.28 & 29,200 \\
27.29 & 29,300 \\
27.30 & 29,300 \\
27.31 & 29,400 \\
27.32 & 29,400
\end{tabular}


This page intentionally left blank. 


\section{APPENDIX B:}

MIDDLE GREEN RIVER FLOODPLAIN WETLAND CONNECTION MAPS FOR 2014 
This page intentionally left blank. 


\section{APPENDIX B:}

\section{MIDDLE GREEN RIVER FLOODPLAIN WETLAND CONNECTION MAPS FOR 2014}

This appendix presents overlays of modeled flow connections on aerial imagery of levee breaches and connection channels for floodplain wetlands surveyed in October 2014. The flow and cross section at which connection is estimated to occur is presented on each figure. For all images shown in the following figures, the date of the aerial imagery differs from the date of the survey, and aerial imagery does not depict exact conditions at the time of the survey. 
This page intentionally left blank. 

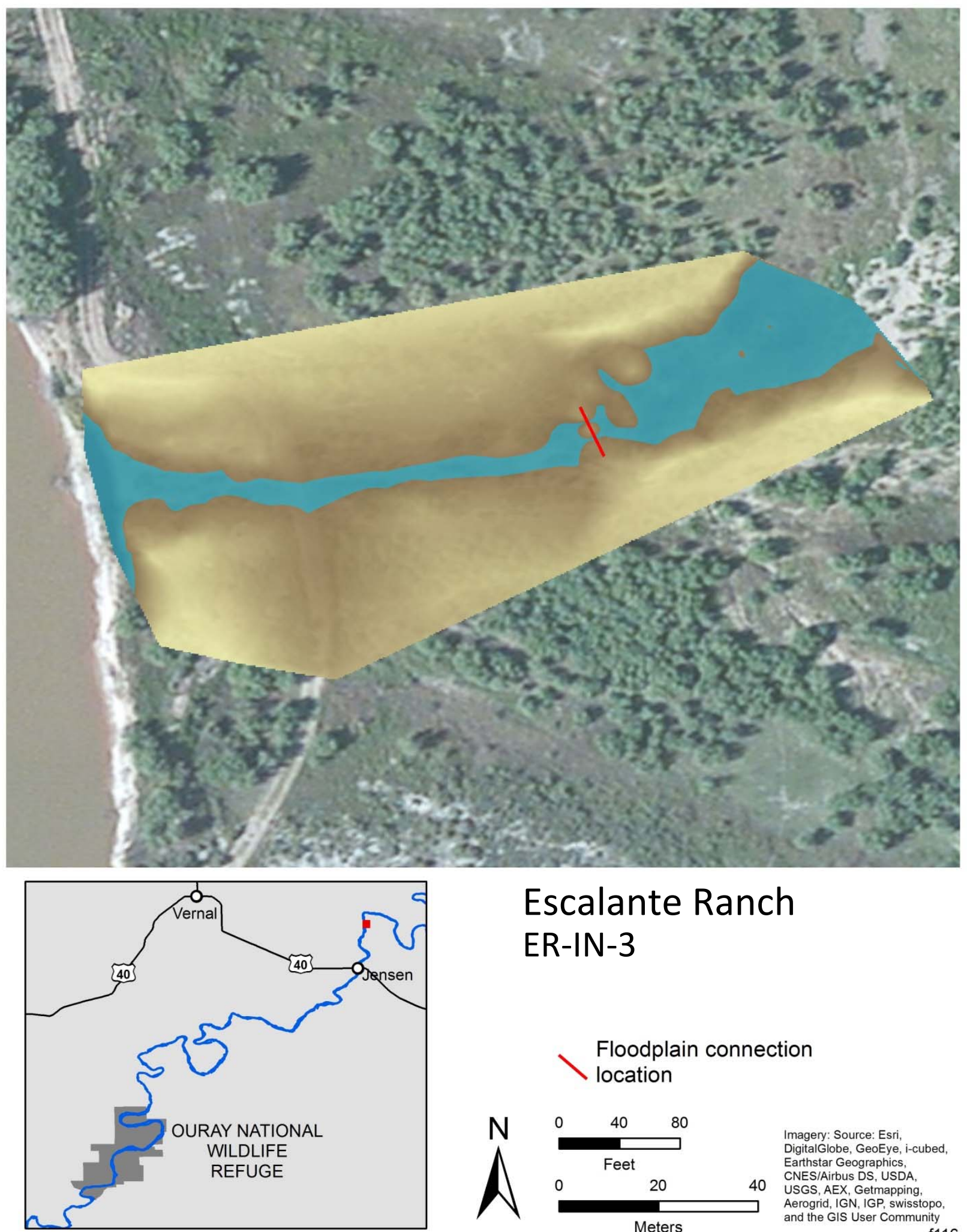

Escalante Ranch ER-IN-3

Floodplain connection
location
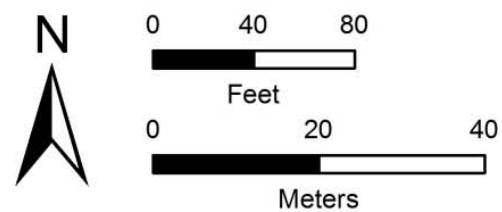

Imagery: Source: Esri,

DigitalGlobe, GeoEye, i-cubed,

Earthstar Geographics,

CNES/Airbus DS, USDA,

Aerogrid, IGN, IGP, swisstopo,

and the GIS User Community

FIGURE B-1 Floodplain Wetland Connection Channel and Minimum Connection Flow for ER-IN-3 at 18,100 cfs in 2014 

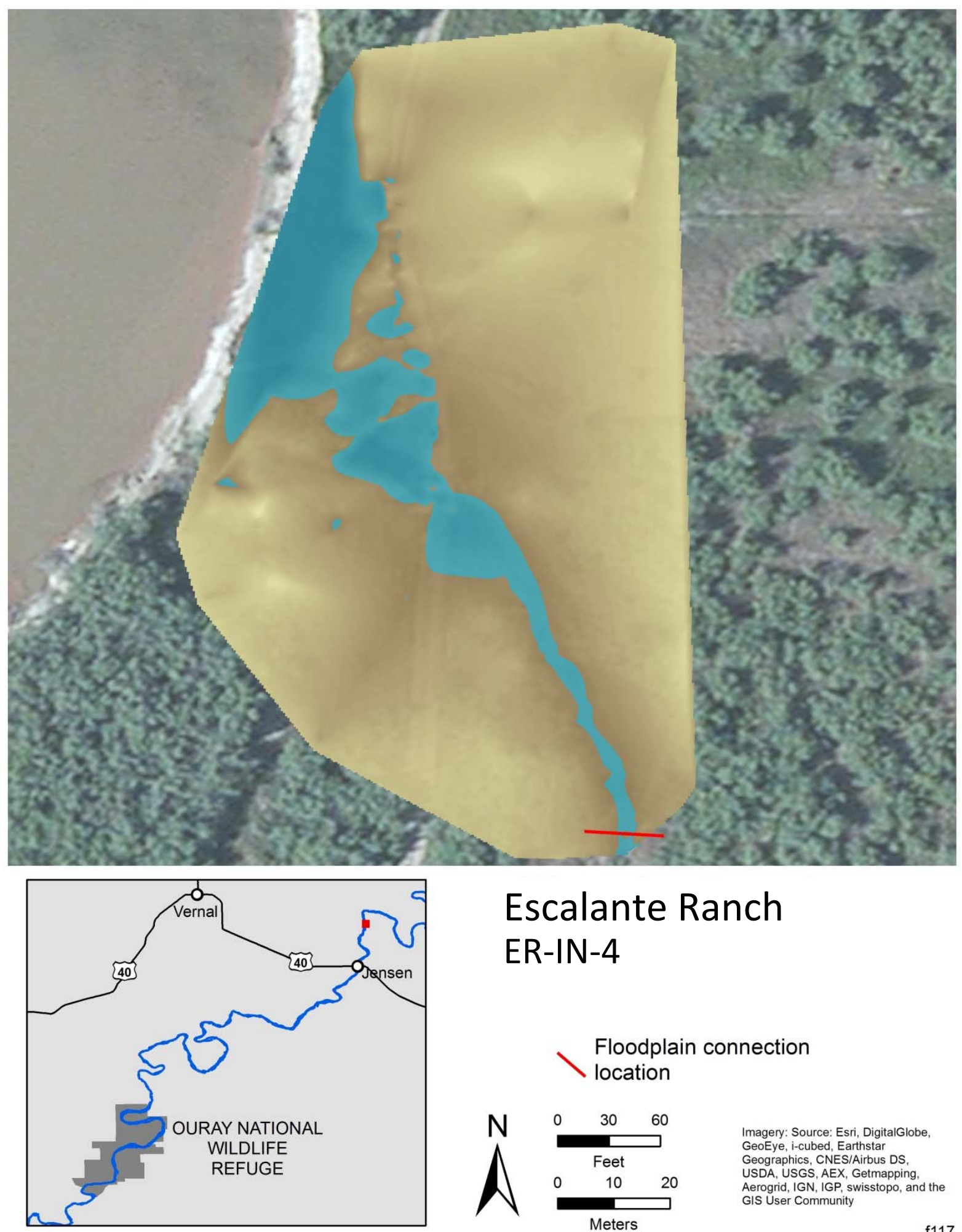

\section{Escalante Ranch ER-IN-4}

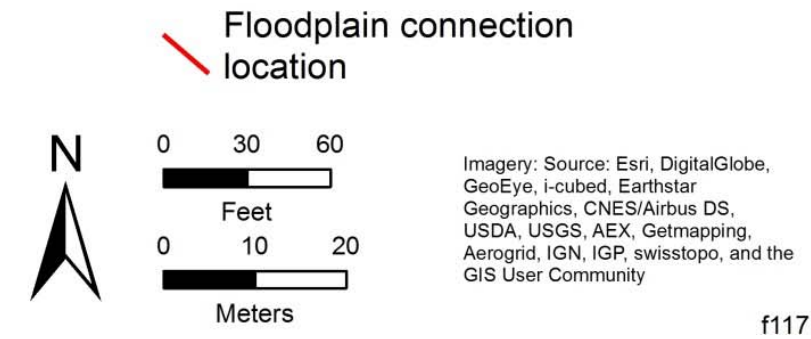

FIGURE B-2 Floodplain Wetland Connection Channel and Minimum Connection Flow for ER-IN-4 at 20,000 cfs in 2014 

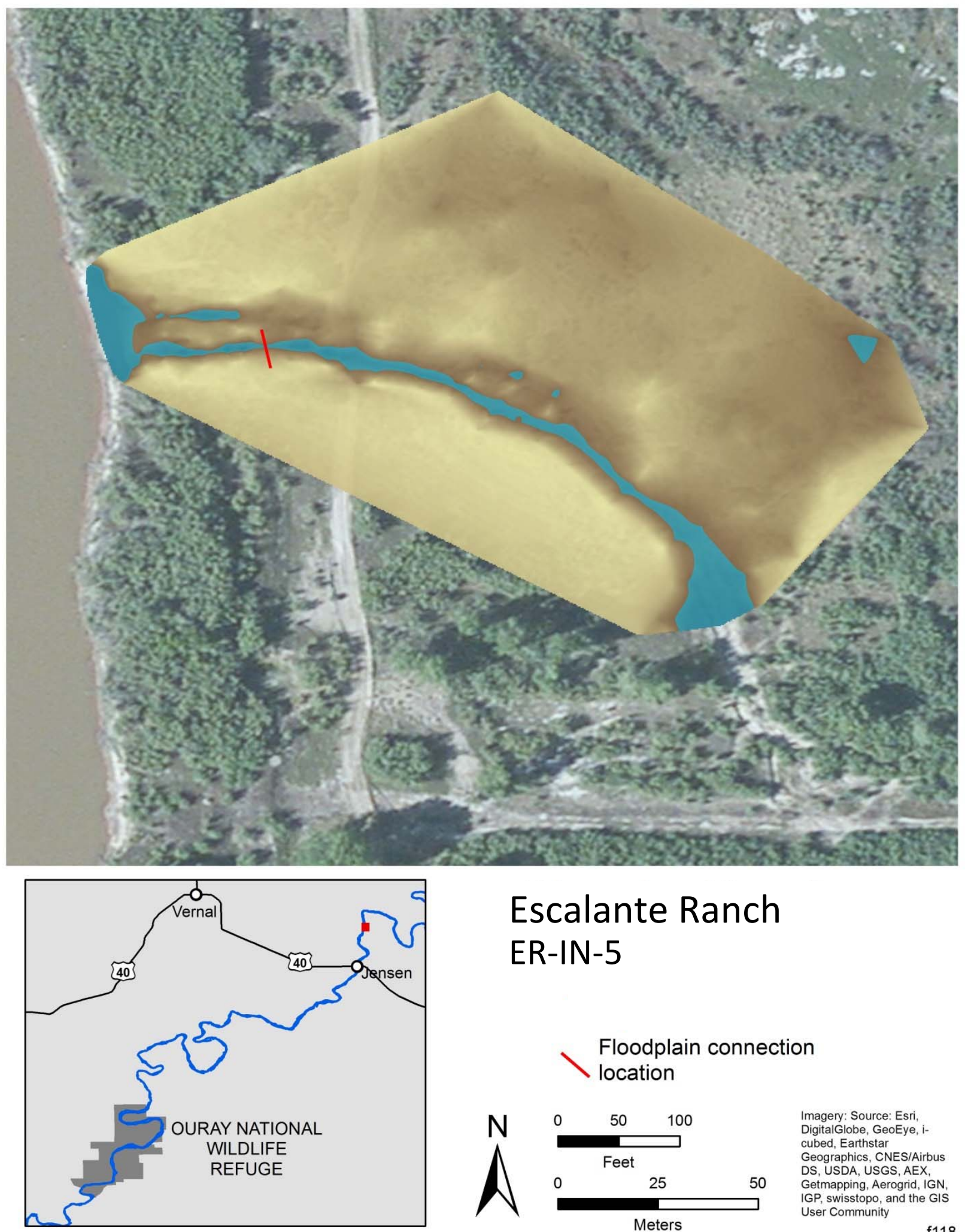

\section{Escalante Ranch ER-IN-5}

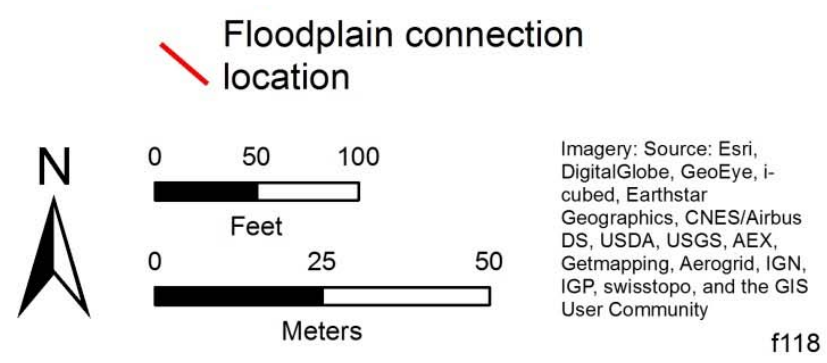

FIGURE B-3 Floodplain Wetland Connection Channel and Minimum Connection Flow for ER-IN-5 at 19,400 cfs in 2014 

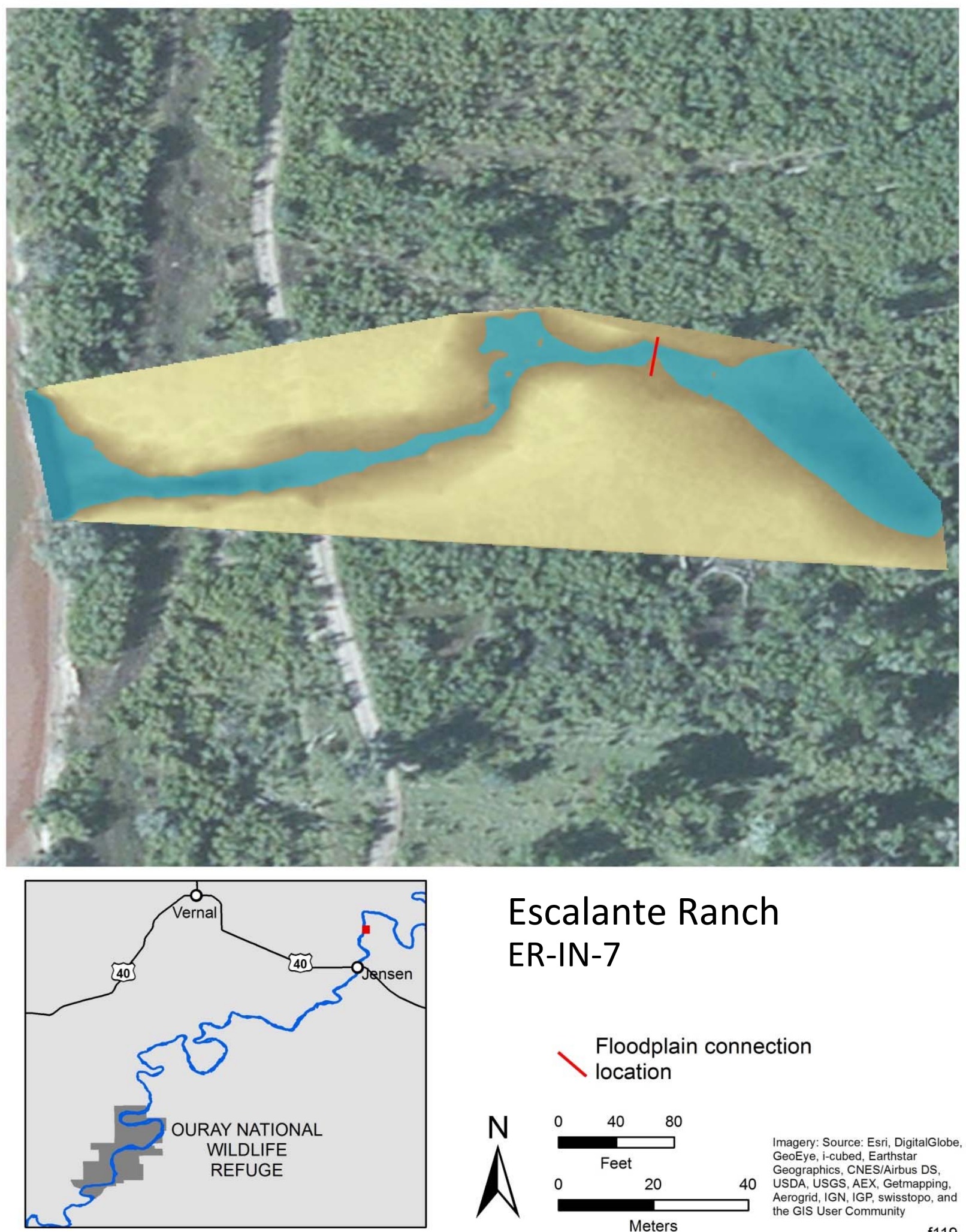

\section{Escalante Ranch}

\section{ER-IN-7}
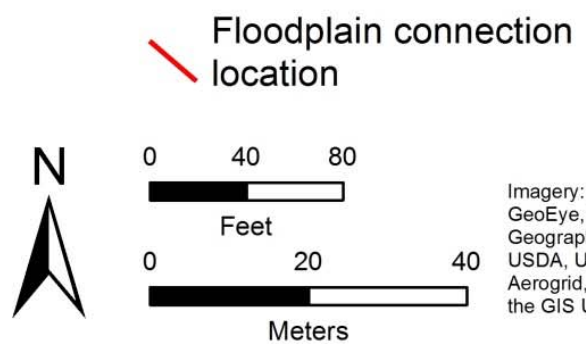

Imagery: Source: Esri, DigitalGlobe, GeoEye, i-cubed, Earthstar Geographics, CNES/Airbus DS USDA, USGS, AEX, Getmapping Aerogrid, IGN, IGP, swisstopo, and the GIS User Community

FIGURE B-4 Floodplain Wetland Connection Channel and Minimum Connection Flow for ER-IN-6 at 18,900 cfs in 2014 

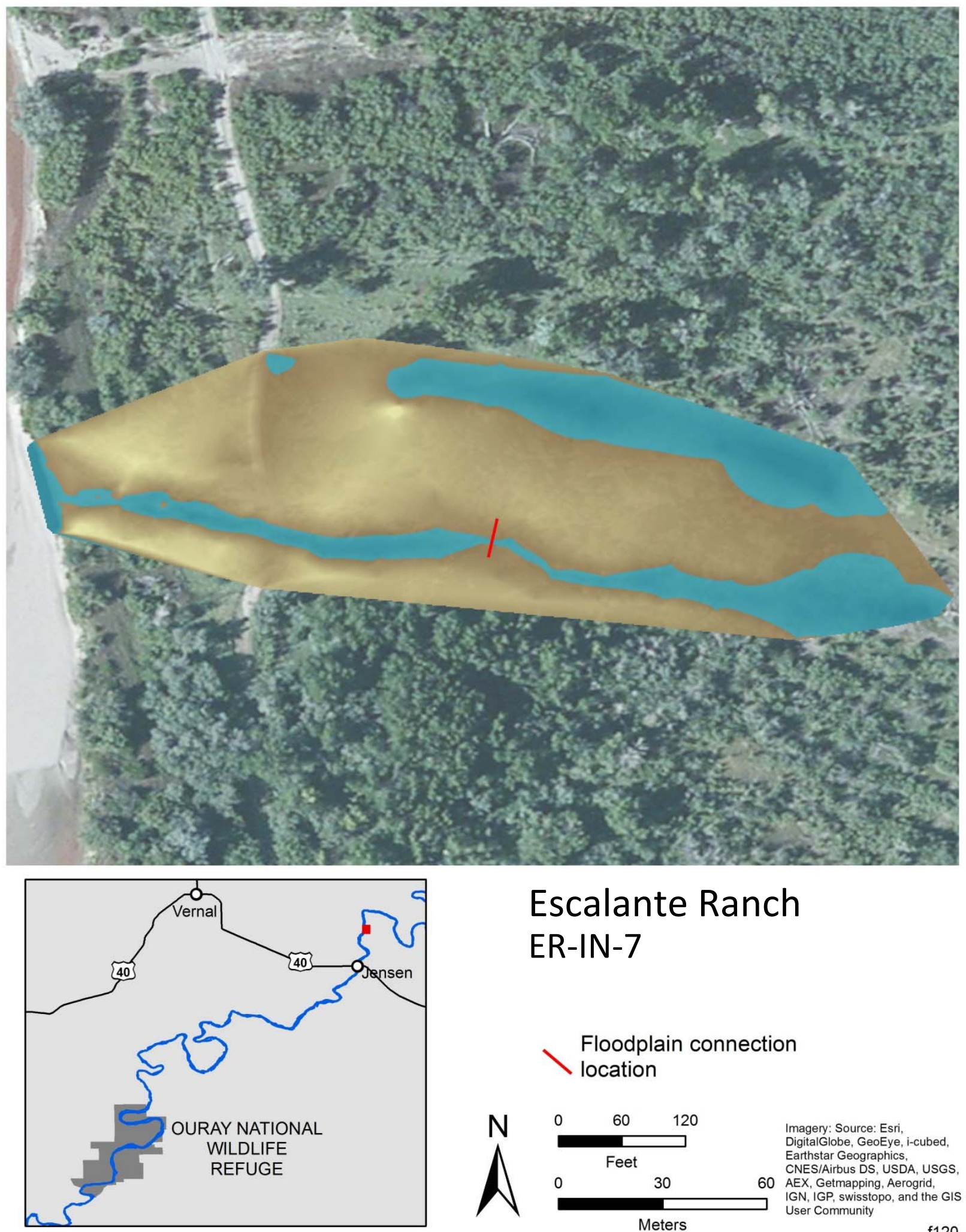

\section{Escalante Ranch ER-IN-7}

Floodplain connection
location
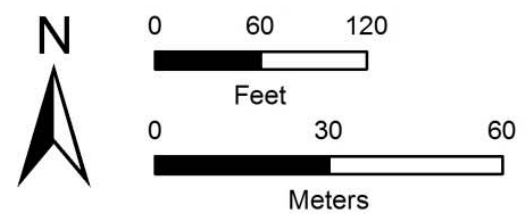

Imagery: Source: Esri,

DigitalGlobe, GeoEye, i-cubed, Earthstar Geographics,

CNES/Airbus DS, USDA, USGS,

AEX, Getmapping, Aerogrid,

IGN, IGP, swisstopo, and the GIS User Community

f120

FIGURE B-5 Floodplain Wetland Connection Channel and Minimum Connection Flow for ER-IN-7 at 17,600 cfs in 2014 

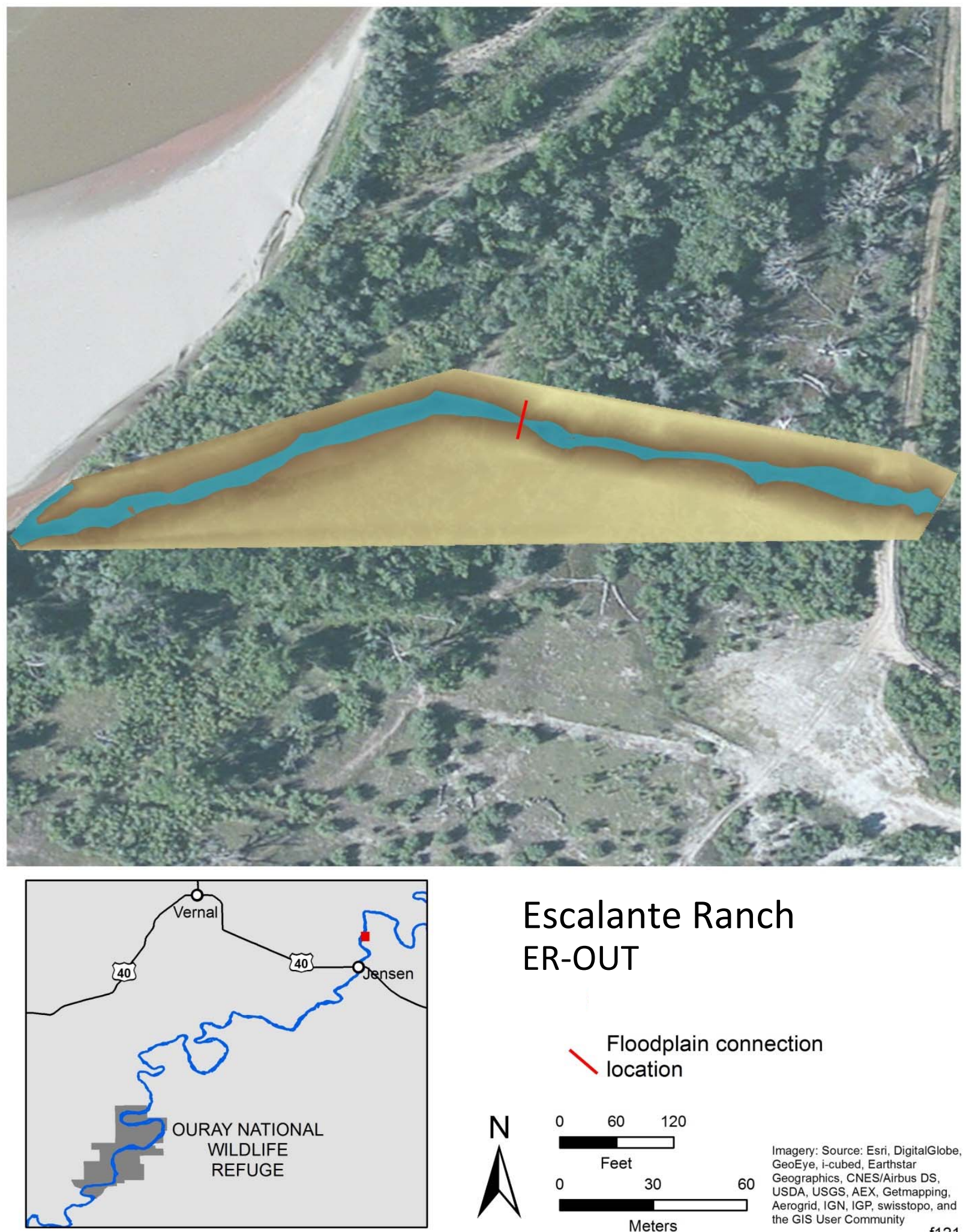

\section{Escalante Ranch ER-OUT}

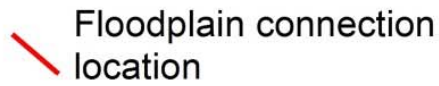

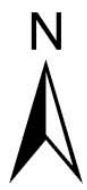

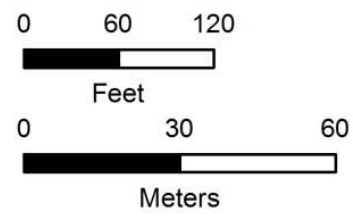

Meters
Imagery: Source: Esri, DigitalGlobe, GeoEye, i-cubed, Earthstar Geographics, CNES/Airbus DS, USDA, USGS, AEX, Getmapping, Aerogrid, IGN, IGP, swisstopo, and
the GIS User Community

FIGURE B-6 Floodplain Wetland Connection Channel and Minimum Connection Flow for ER-OUT at 8,740 cfs in 2014 

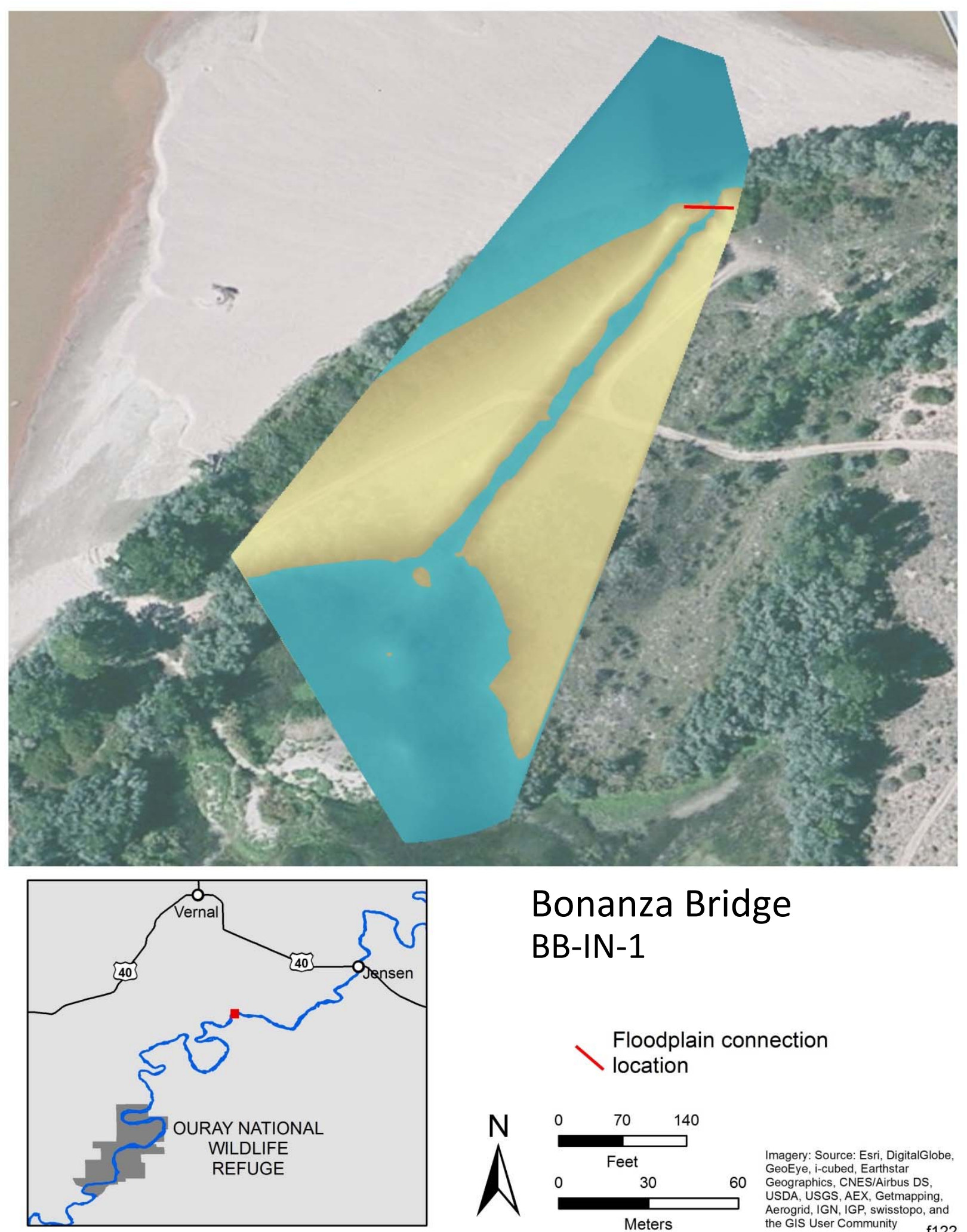

\title{
Bonanza Bridge BB-IN-1
}

\author{
Floodplain connection \\ location
}
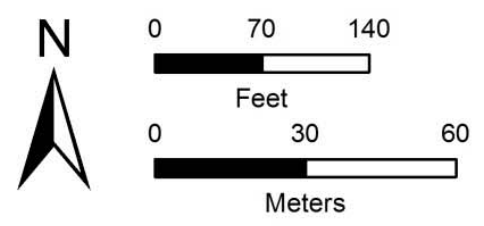

Imagery: Source: Esri, DigitalGlobe GeoEye, i-cubed, Earthstar

Geographics, CNES/Airbus DS,

USDA, USGS, AEX, Getmapping,
Aerogrid, IGN, IGP, swisstopo, and the GIS User Community f122

FIGURE B-7 Floodplain Wetland Connection Channel and Minimum Connection Flow for BB-IN-1 at 19,800 cfs in 2014 

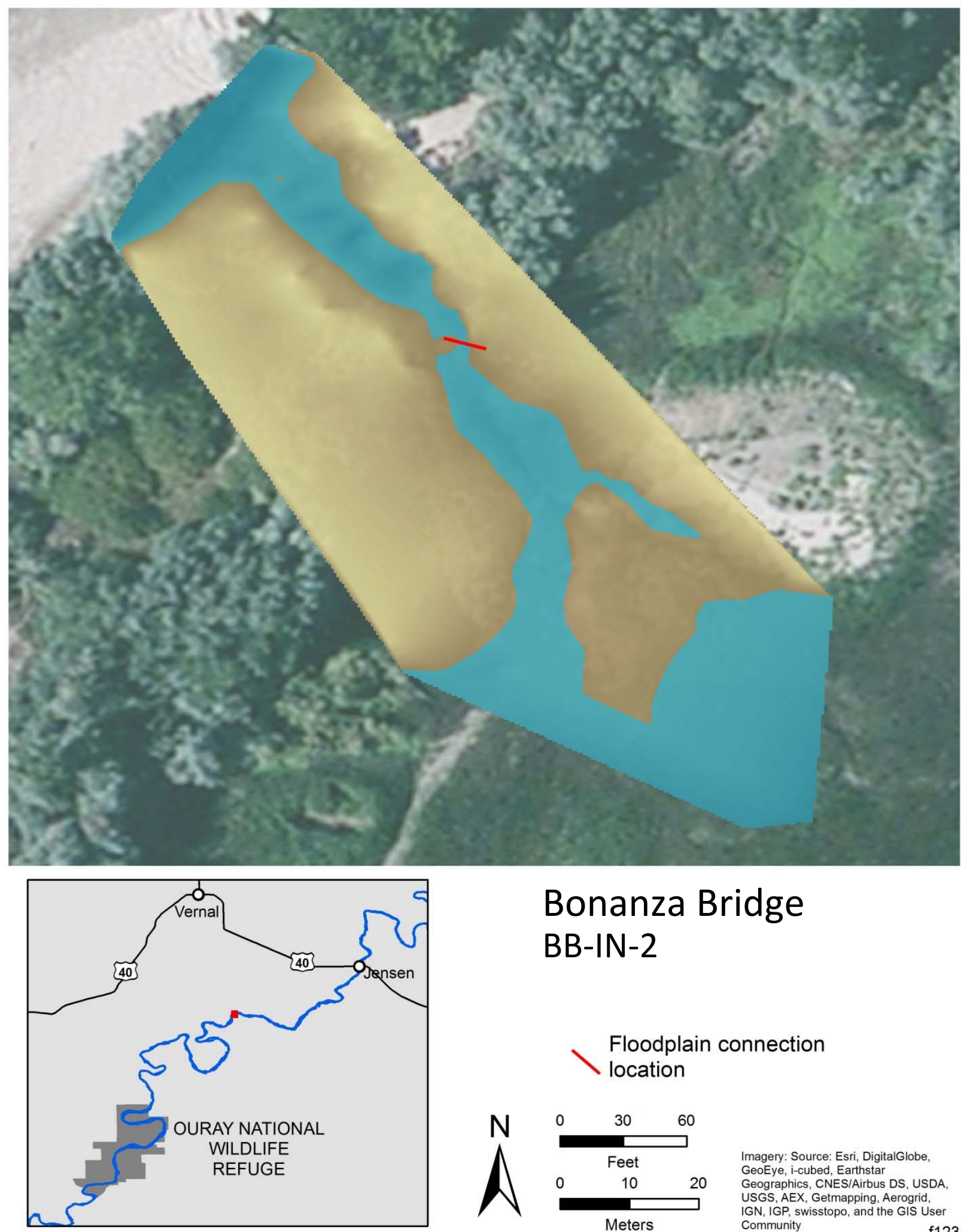

\section{Bonanza Bridge BB-IN-2}
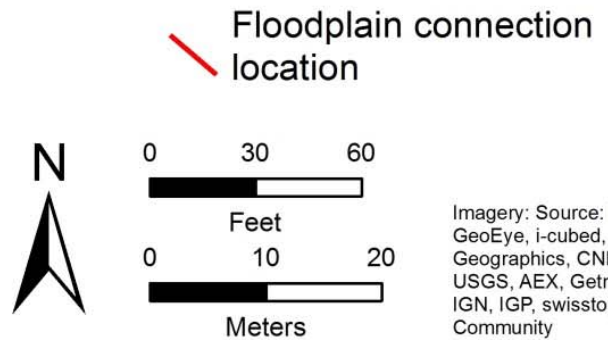

Imagery: Source: Esri, DigitalGlobe, GeoEye, i-cubed, Earthstar Geographics, CNES/Airbus DS, USDA, USGS, AEX, Getmapping, Aerogrid,
IGN, IGP, swisstopo, and the GIS Use Community

FIGURE B-8 Floodplain Wetland Connection Channel and Minimum Connection Flow for BB-IN-2 at 20,500 cfs in 2014 

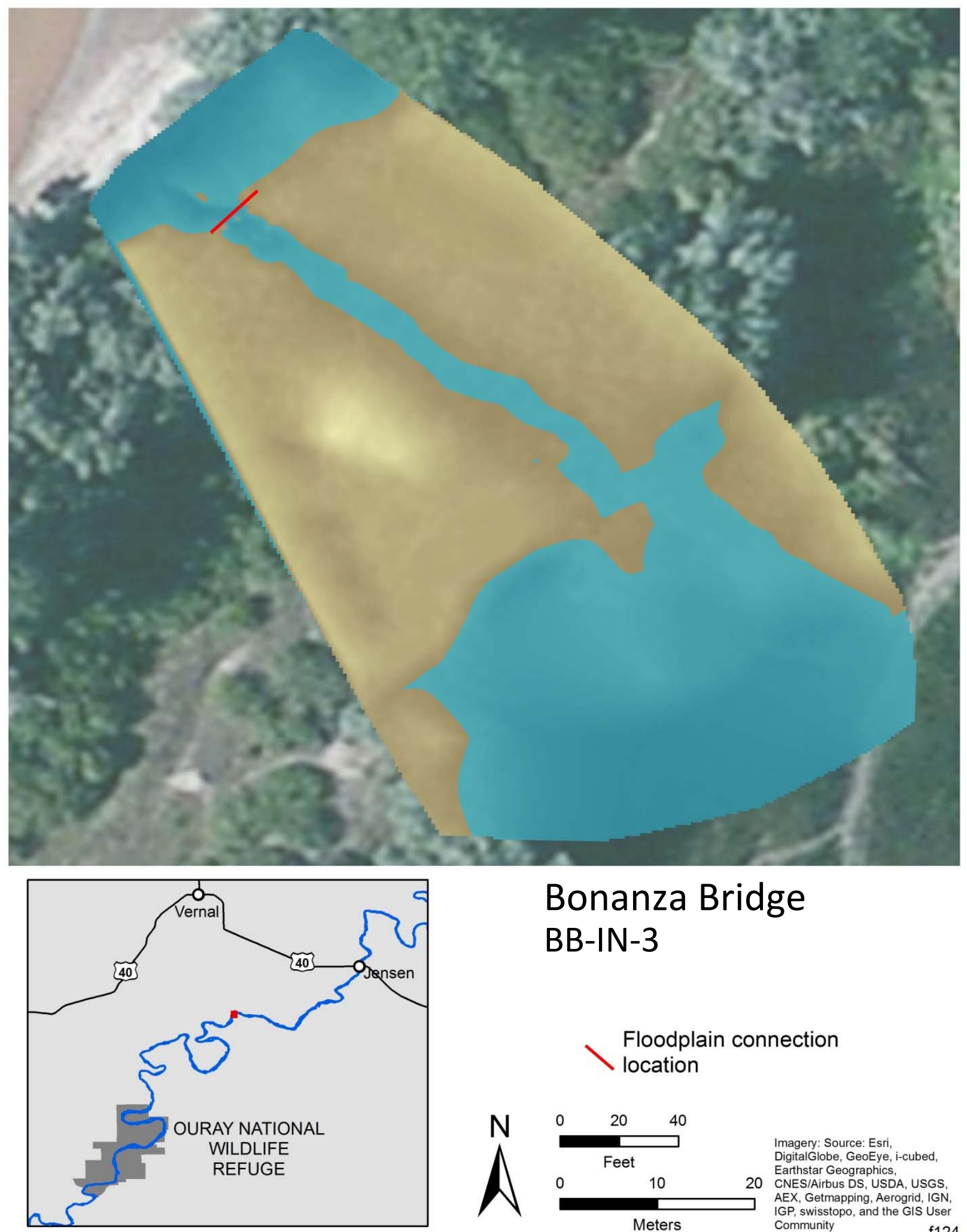

Bonanza Bridge BB-IN-3

Floodplain connection location
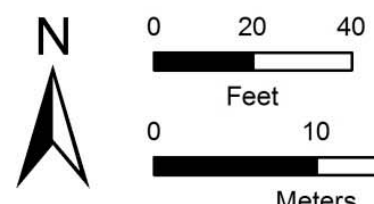

Imagery: Source: Esri, DigitalGlobe, GeoEye, i-cubed, Earthstar Geographics,

01020 CNES/Airbus DS, USDA, USGS AEX, Getmapping, Aerogrid, IGN IGP, swisstopo, and the GIS User Meters Community

FIGURE B-9 Floodplain Wetland Connection Channel and Minimum Connection Flow for BB-IN-3 at 22,200 cfs in 2014 

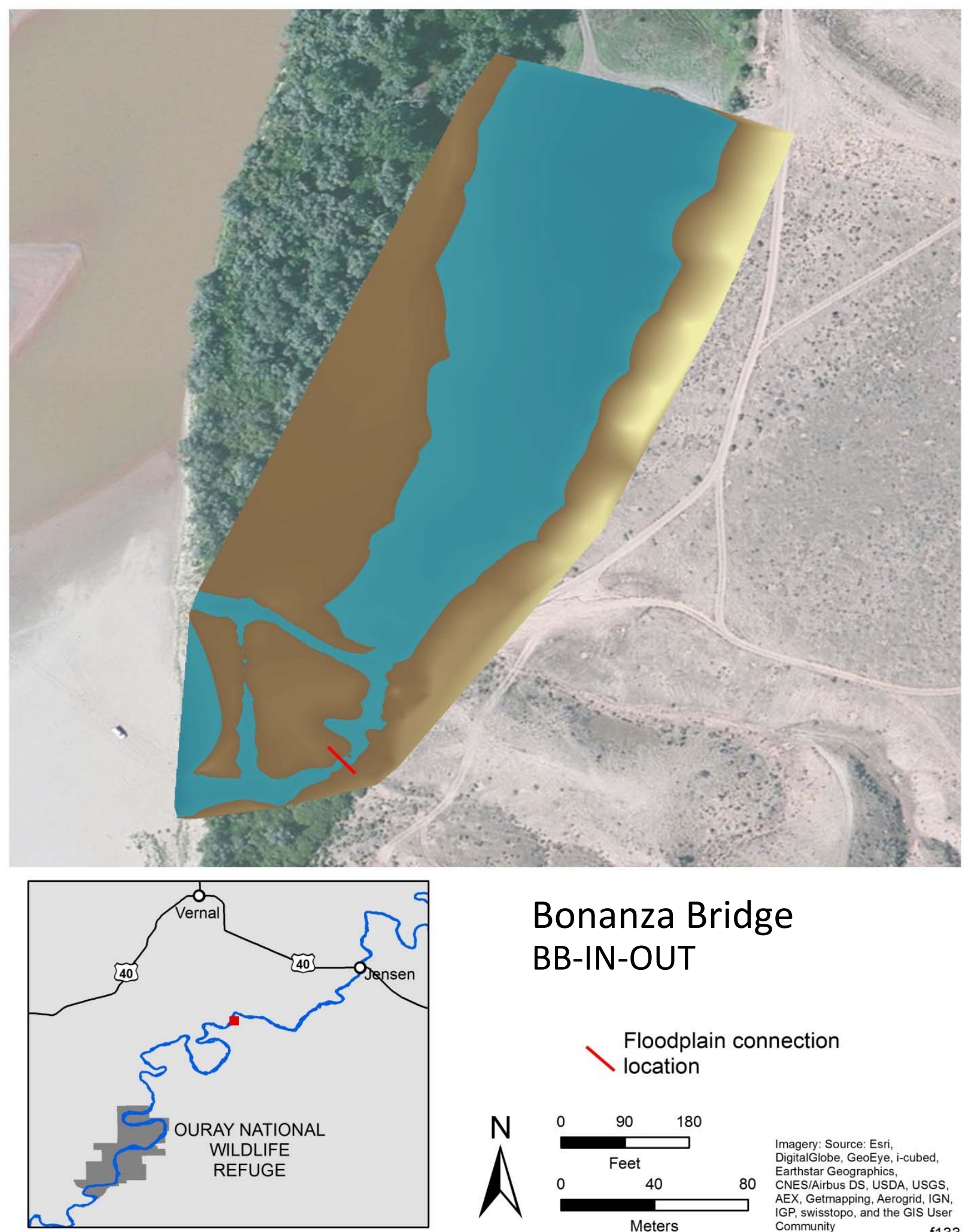

\section{Bonanza Bridge BB-IN-OUT}

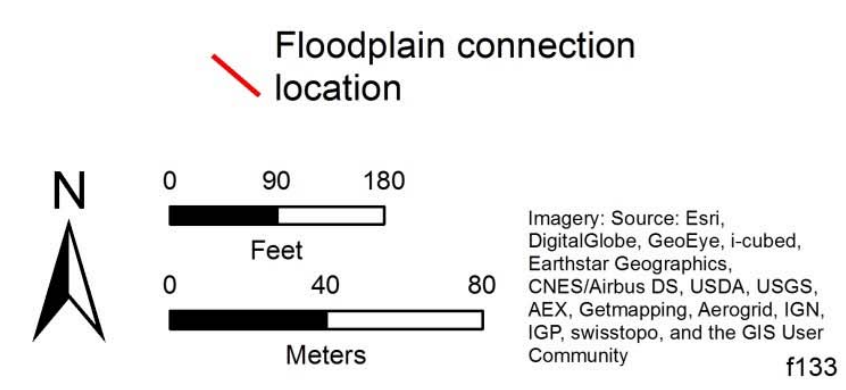

FIGURE B-10 Floodplain Wetland Connection Channel and Minimum Connection Flow for BB-OUT at 14,900 cfs in 2014 


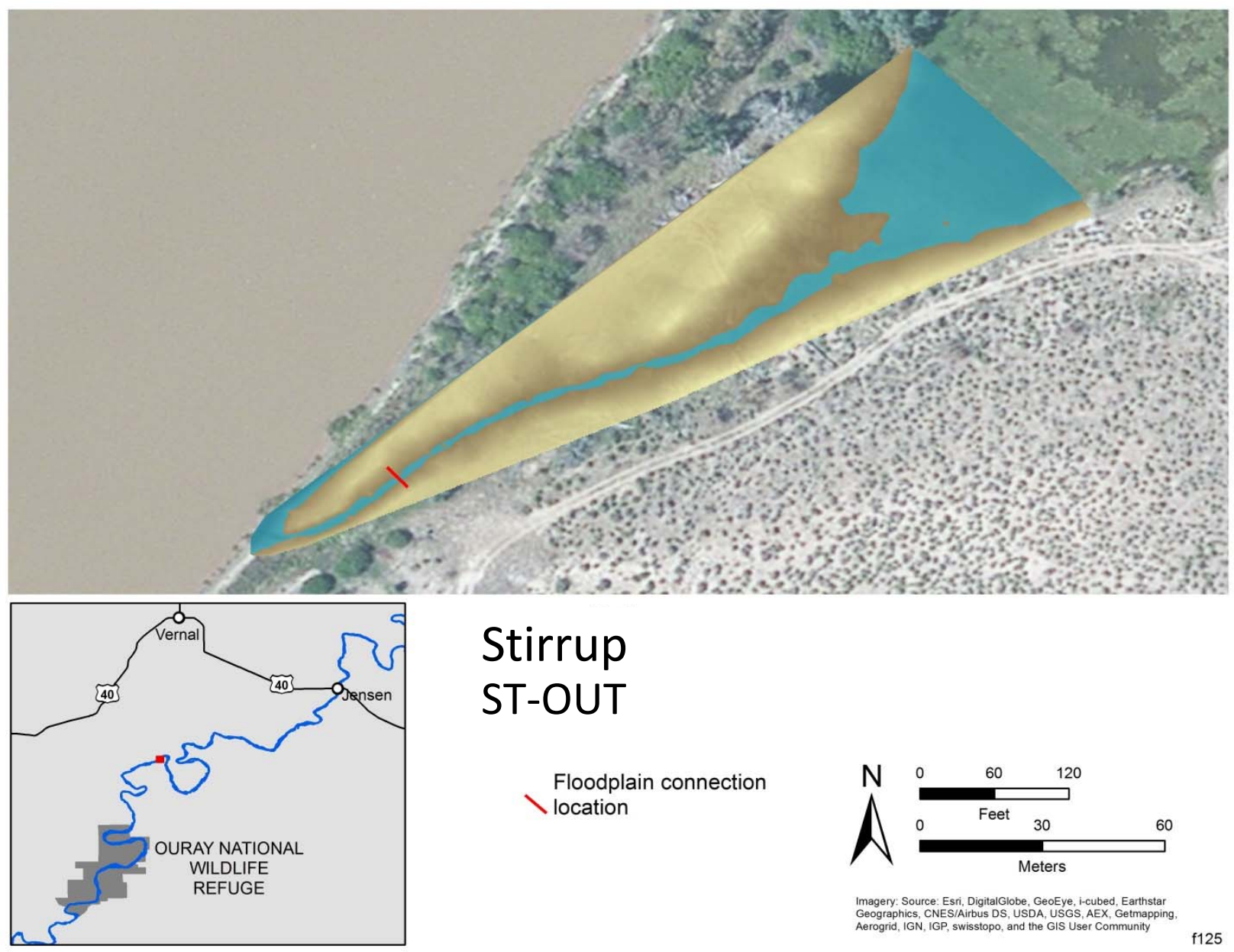

FIGURE B-11 Floodplain Wetland Connection Channel and Minimum Connection Flow for ST-OUT at 15,700 cfs in 2014 

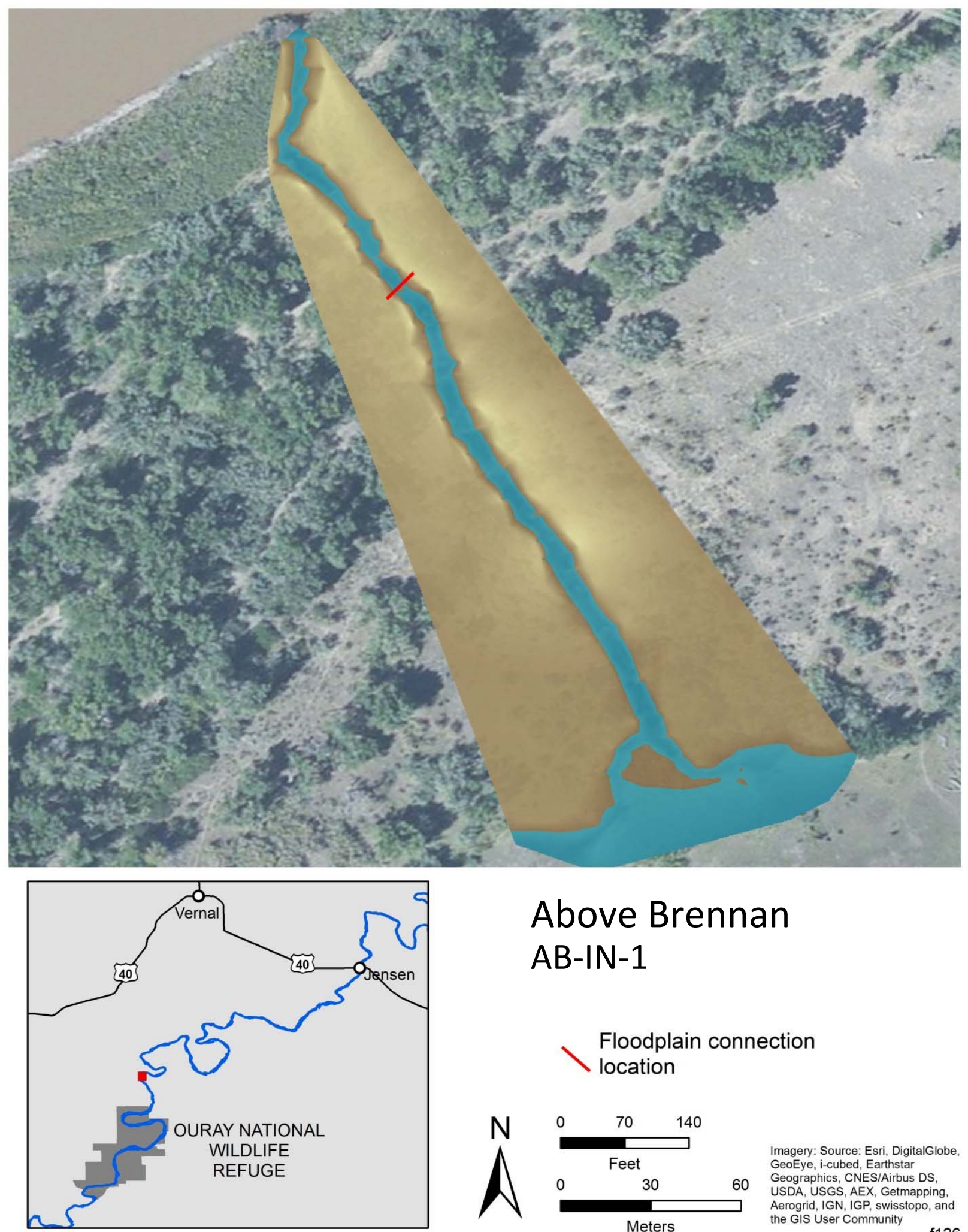

\title{
Above Brennan
} AB-IN-1

\author{
Floodplain connection \\ location
}
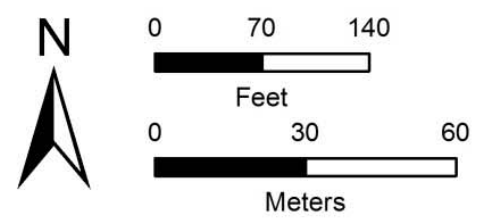

Imagery: Source: Esri, DigitalGlobe, GeoEye, i-cubed, Earthstar

Geographics, CNES/Airbus DS, Aerogrid, IGN, IGP, swisstopo, and the GIS User Community 

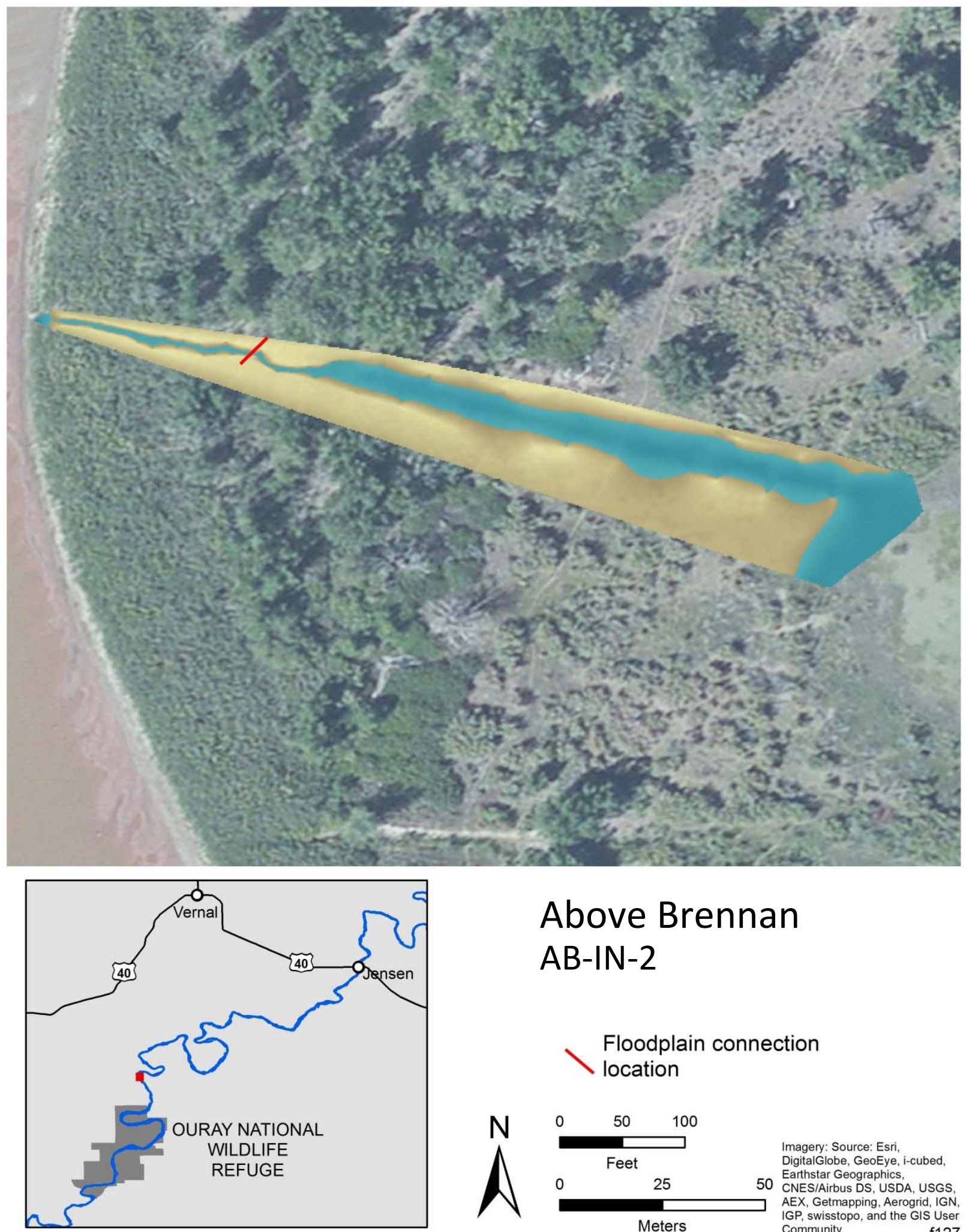

\section{Above Brennan}

AB-IN-2

Floodplain connection
location

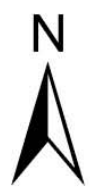

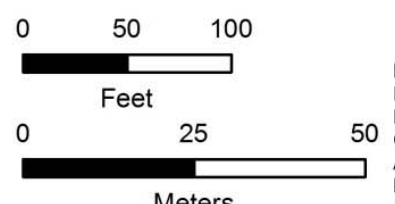

Meters magery: Source: Esri,

DigitalGlobe, GeoEye, i-cubed, Earthstar Geographics, CNES/Airbus DS, USDA, USGS, AEX, Getmapping, Aerogrid, IGN, Community

FIGURE B-13 Floodplain Wetland Connection Channel and Minimum Connection Flow for AB-IN-2 at 19,100 cfs in 2014 

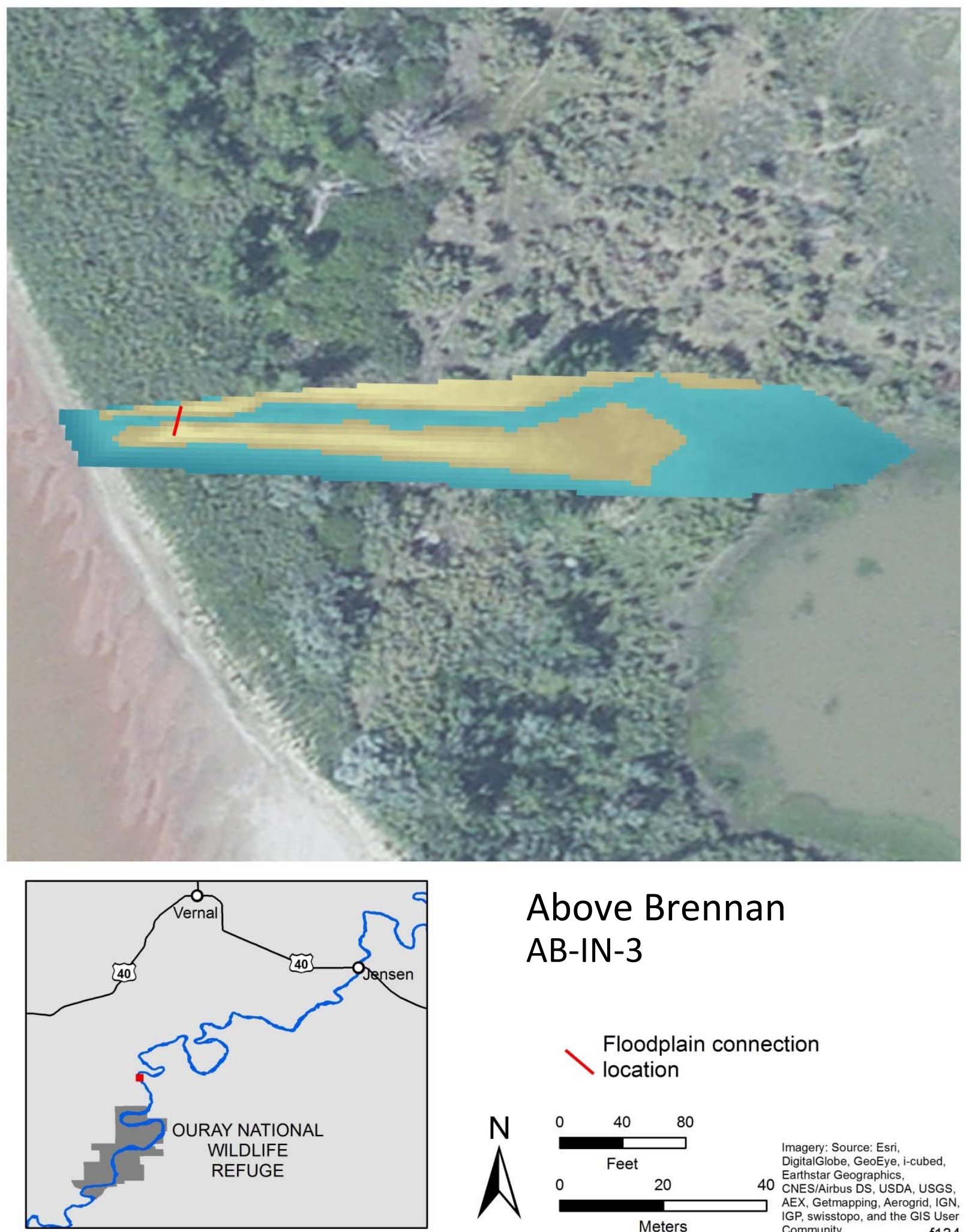

\section{Above Brennan AB-IN-3}
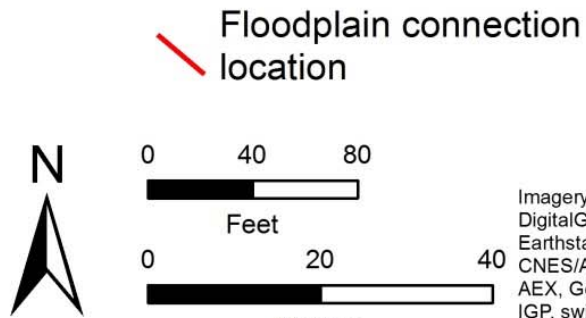

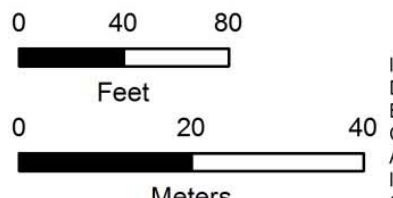

Meters magery: Source: Esri, DigitalGlobe, GeoEye, i-cubed, Earthstar Geographics, CNES/Airbus DS, USDA, USGS, AEX, Getmapping, Aerogrid, IGN, Community

FIGURE B-14 Floodplain Wetland Connection Channel and Minimum Connection Flow for AB-IN-3 at 14,600 cfs in 2014 

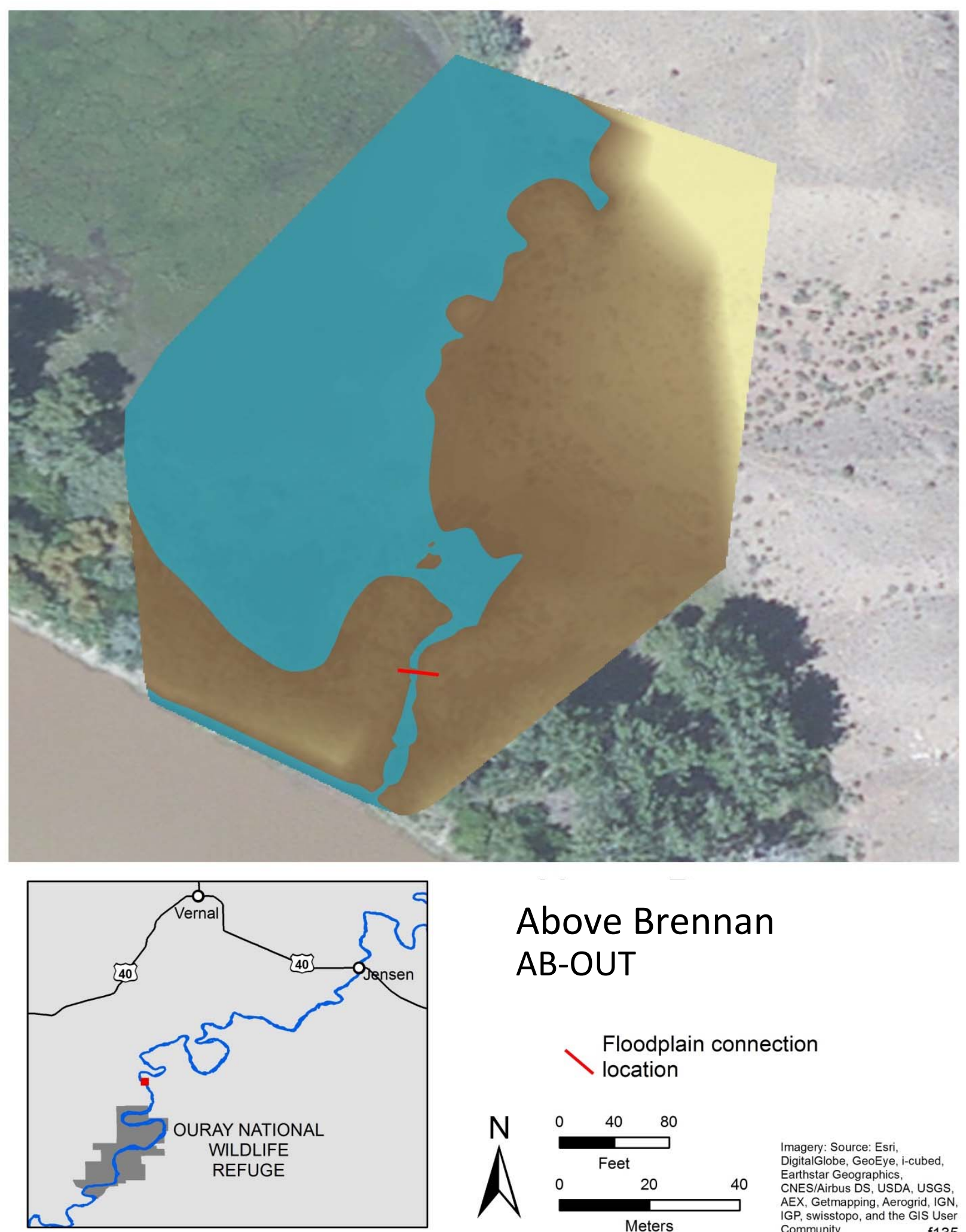

\section{Above Brennan AB-OUT}

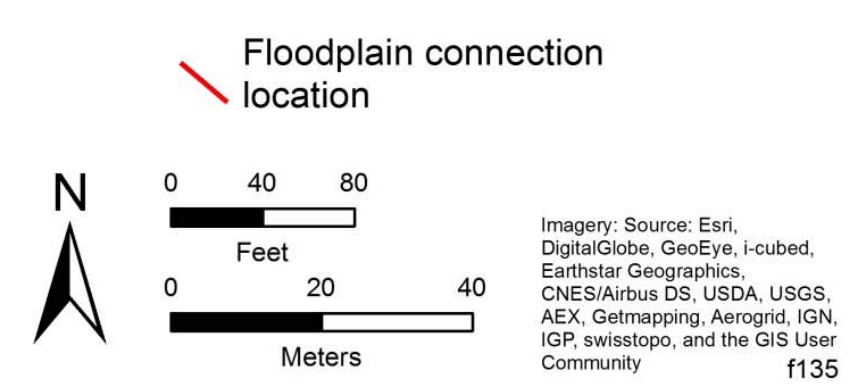

FIGURE B-15 Floodplain Wetland Connection Channel and Minimum Connection Flow for AB-OUT at 10,400 cfs in 2014 

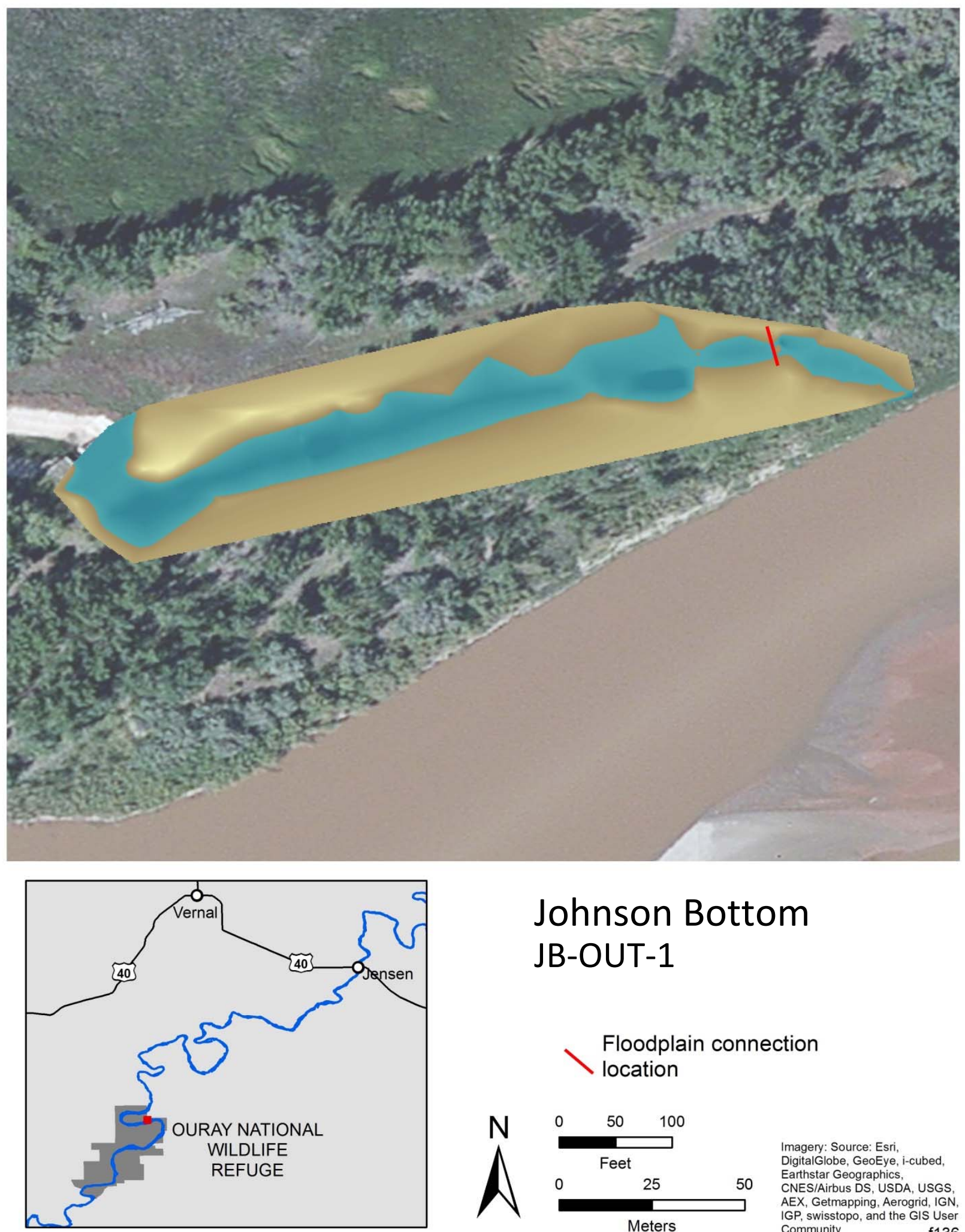

\title{
Johnson Bottom JB-OUT-1
}

\author{
Floodplain connection \\ location
}
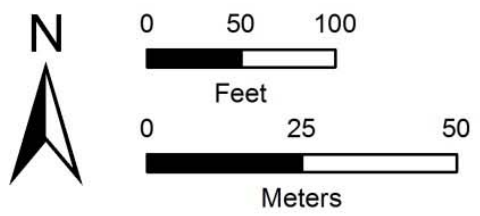

Imagery: Source: Esri,

DigitalGlobe, GeoEye, i-cubed,

Earthstar Geographics,

CNES/Airbus DS, USDA, USGS,

AEX, Getmapping, Aerogrid, IGN,

Community

f136

FIGURE B-16 Floodplain Wetland Connection Channel and Minimum Connection Flow for JB-OUT-1 at 13,600 cfs in 2014 

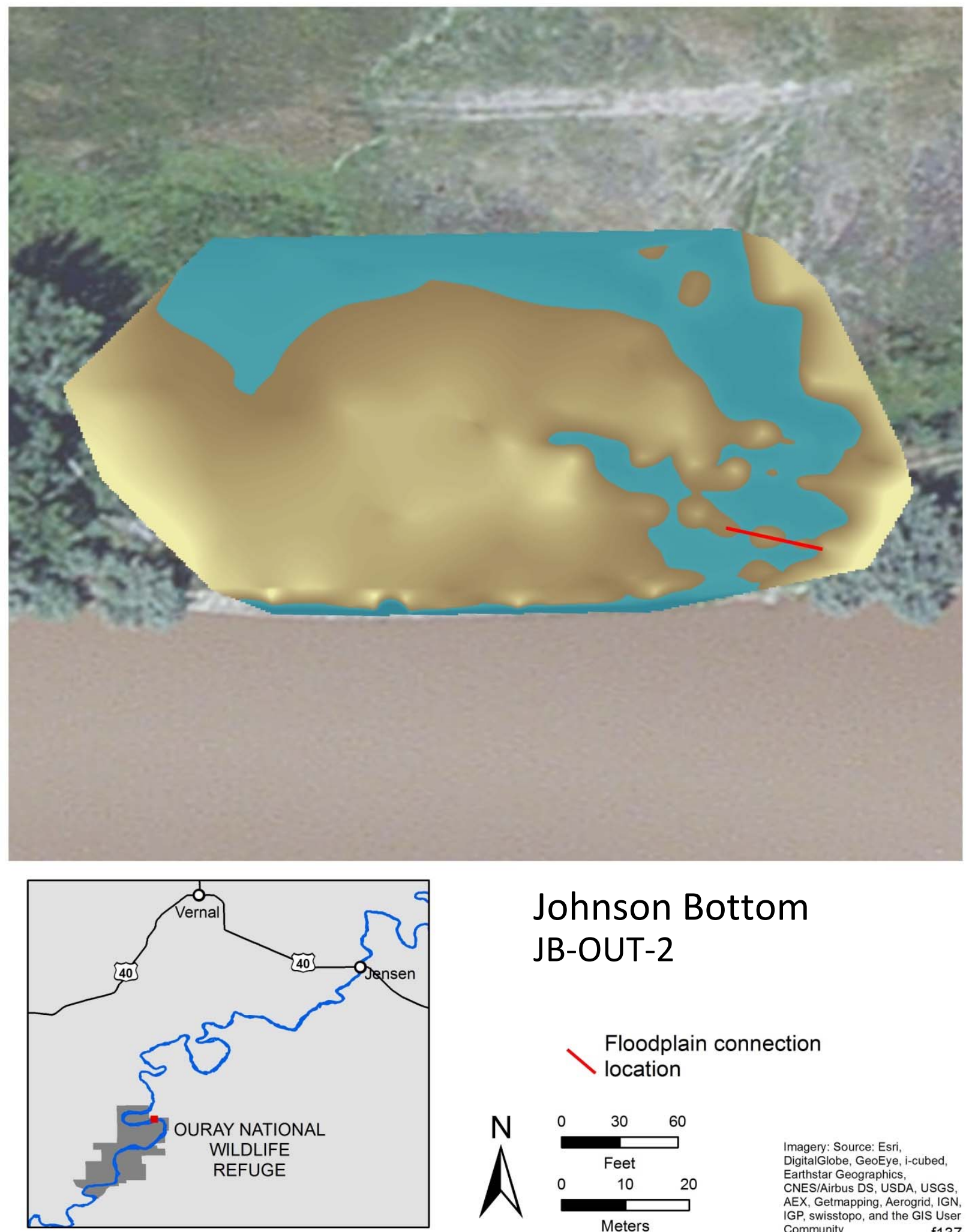

\section{Johnson Bottom JB-OUT-2}

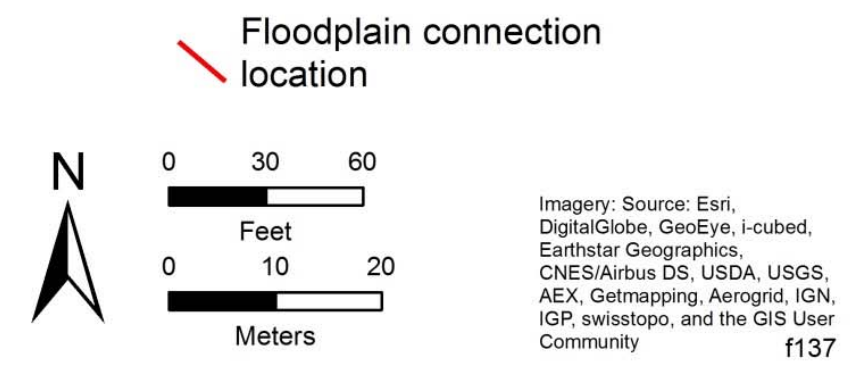

FIGURE B-17 Floodplain Wetland Connection Channel and Minimum Connection Flow for JB-OUT-2 at 14,100 cfs in 2014 

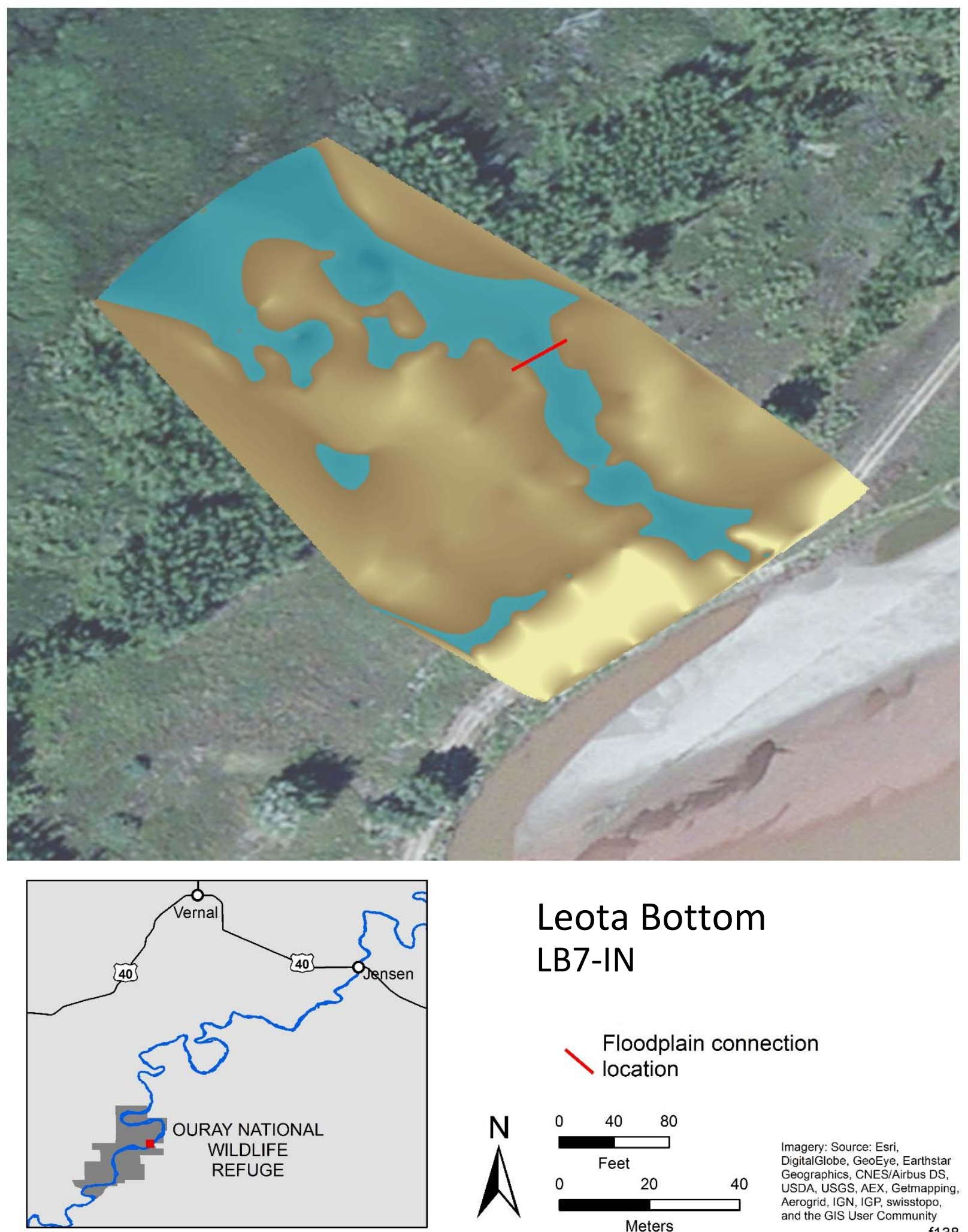

\section{Leota Bottom} LB7-IN

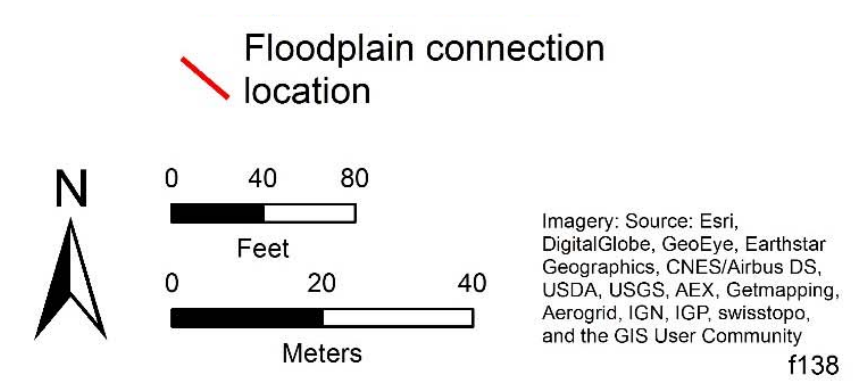

FIGURE B-18 Floodplain Wetland Connection Channel and Minimum Connection Flow for LB7-IN at 14,500 cfs in 2014 

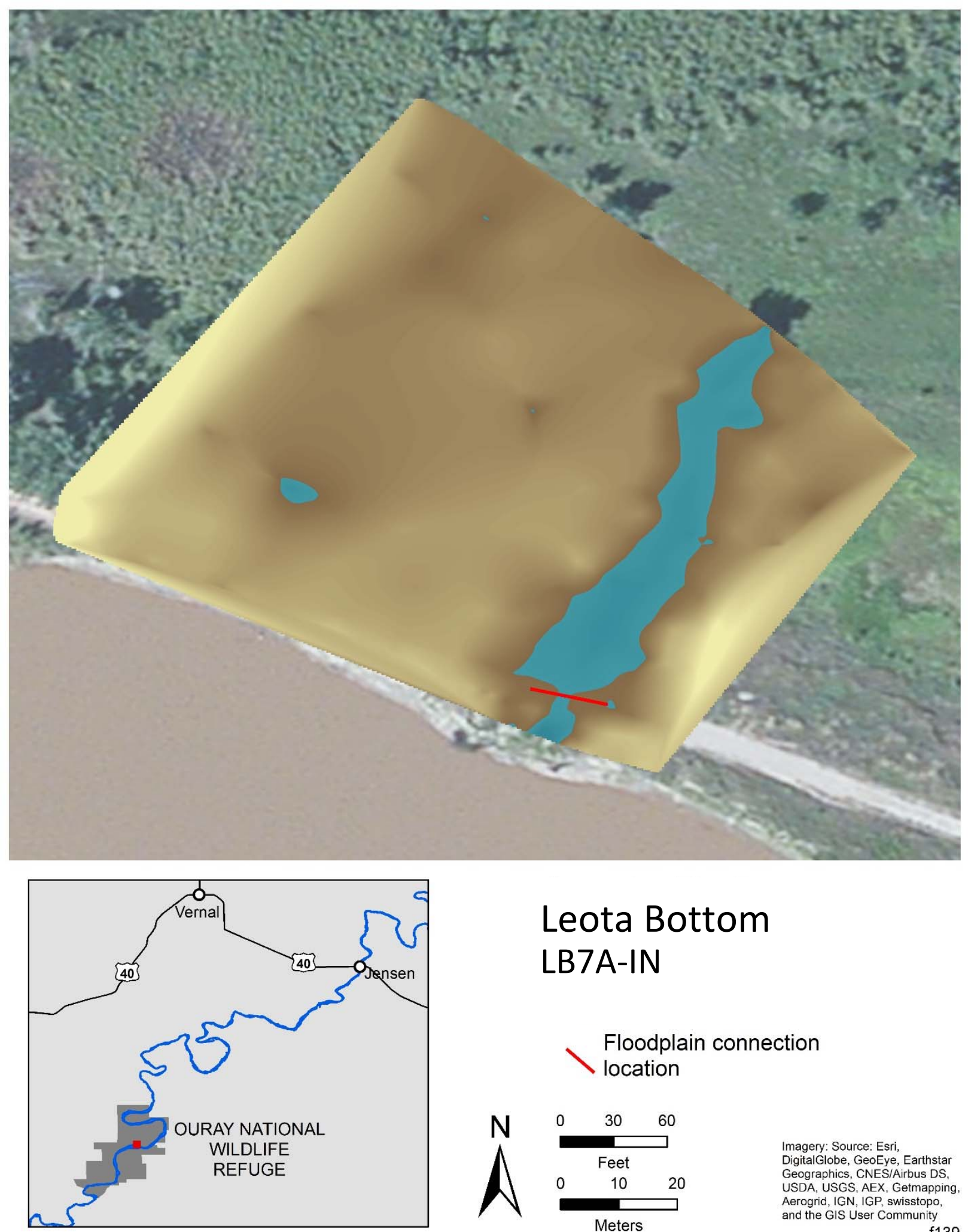

\section{Leota Bottom}

\section{LB7A-IN}

Floodplain connection

location
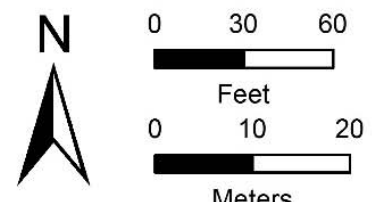

Imagery: Source: Esri,

DigitalGlobe, GeoEye, Earthstar Geographics, CNES/Airbus DS,

USDA, USGS, AEX, Getmapping, Aerogrid, IGN, IGP, swisstopo

Meters

FIGURE B-19 Floodplain Wetland Connection Channel and Minimum Connection Flow for LB7A-IN at 12,700 cfs in 2014 


\section{Argonne}

\section{Environmental Science Division}

Argonne National Laboratory

9700 South Cass Avenue, Bldg. 240

Argonne, IL 60439-4847

www.anl.gov 